University of Baltimore Law ScholarWorks@University of Baltimore School of Law

\title{
Preventing the Curse of Bigness Through Conglomerate Merger Legislation
}

\author{
Robert H. Lande \\ University of Baltimore School of Law, rlande@ubalt.edu \\ Sandeep Vaheesan \\ Open Markets Institute, vaheesan@openmarketsinstitute.org
}

Follow this and additional works at: https://scholarworks.law.ubalt.edu/all_fac

Part of the Antitrust and Trade Regulation Commons

\section{Recommended Citation}

Robert H. Lande \& Sandeep Vaheesan, Preventing the Curse of Bigness Through Conglomerate Merger Legislation, 52 Arizona State Law Journal 75 (2020).

Available at: https://scholarworks.law.ubalt.edu/all_fac/1102

This Article is brought to you for free and open access by the Faculty Scholarship at ScholarWorks@University of Baltimore School of Law. It has been accepted for inclusion in All Faculty Scholarship by an authorized administrator of ScholarWorks@University of Baltimore School of Law. For more information, please contact hmorrell@ubalt.edu. 


\title{
Preventing the Curse of Bigness Through Conglomerate Merger Legislation
}

\author{
Robert H. Lande \& Sandeep Vaheesan*
}

\begin{abstract}
The antitrust laws, as they are presently interpreted, are incapable of blocking most of the very largest corporate mergers. They successfully blocked only three of the seventy-eight largest finalized mergers and acquisitions (defined as the acquired firm being valued at more than $\$ 10$ billion) that occurred between 2015 and 2019. The antitrust laws also would permit the first trillion-dollar corporation, Apple, to merge with the previously third largest corporation, Exxon/Mobil. In fact, today every U.S. corporation could merge until just ten were left-so long as each owned only $10 \%$ of every relevant market.

Even though the Congresses that enacted the anti-merger laws did so, among other aims, to limit the political power of corporations, today the federal antitrust agencies and courts interpret these laws only in terms of price and other economic effects within discrete markets. Under current merger practice, the enhanced political power of corporations is irrelevant.

However, from Senators Elizabeth Warren and Bernie Sanders on the left, to President Trump and many others on the right, there is a renewed interest in using antitrust to control corporate size, structure, and practices. There is popular desire both to prevent large mergers and to break up existing companies, such as Facebook and Google, that achieved their dominant positions in part due to acquisitions.

In light of recent developments within most of the political spectrum, this Article proposes model conglomerate merger legislation suitable for our era. This legislation would target every merger that exceeds clearly specified asset thresholds. We are proposing a law that would block every merger in which both firms have assets exceeding \$10 billion, unless they spin-off assets so that their increase in size falls below this figure. This threshold would
\end{abstract}

\footnotetext{
*Author Lande is Venable Professor of Law, University of Baltimore School of Law. Author Vaheesan is Legal Director at the Open Markets Institute. The authors are grateful to Neil W. Averitt, Matthew Buck, Henry F. Carey, Kenneth M. Davidson, Albert A. Foer, Diana Moss, and Howard Marvel for extremely helpful comments and suggestions, and to Nicholas Jordan and Jonathan Gross for excellent research assistance. All of the opinions expressed in this Article should be attributed only to the authors.
} 
block at most approximately fifteen to twenty-five of the largest mergers each year.

This Article undertakes a legal, economic, and political analysis of conglomerate merger legislation. This demonstrates that our proposed legislation would: (1) Produce no significant losses in corporate efficiency; (2) Be clearer and more predictable than the existing anti-merger laws and thus would enhance the rule of law; and (3) Help prevent significant increases in corporate political power and other forms of non-economic power caused by the largest mergers.

\section{INTRODUCTION}

The U.S. antitrust laws today provide a very limited check on corporate consolidation. For example, they successfully blocked only three of the seventy-eight largest finalized mergers and acquisitions (defined as the smaller firm being valued at more than $\$ 10$ billion by the acquirer) that occurred between 2015 and 2019. ${ }^{1}$ They also would permit the first trillion dollar corporation, Apple, ${ }^{2}$ to merge with the third largest (as of the summer of 2019), Exxon/Mobil. ${ }^{3}$ In fact, today every U.S. corporation could merge until just ten were left - so long as each owned only $10 \%$ of every relevant market. ${ }^{4}$

1. In addition, many of these eighty-three mergers were permitted subject to relatively minor divestitures or conduct relief. See infra Appendix II.

2. Rob Davies, Apple Becomes World's First Trillion-Dollar Company, GuARDIAN (Aug. 2, 2018), https://www.theguardian.com/technology/2018/aug/02/apple-becomes-worlds-firsttrillion-dollar-company [https://perma.cc/5WXR-NWCC]. Of course, the market capitalization value of Apple constantly fluctuates.

3. See Erin Duffin, The 100 Largest Companies in the World by Market Value in 2018, StATisTA (Aug. 12, 2019), https://www.statista.com/statistics/263264/top-companies-in-theworld-by-market-value/ [https://perma.cc/3MED-H6VZ]. If these corporations overlap to any potentially anticompetitive degree, such that the effects of the overlaps "may be substantially to lessen competition, or to tend to create a monopoly," the overlaps could be spun off. See 15 U.S.C. $\S 18$ (2019). There also is a chance these companies could be found to compete in one or more relevant "data markets" - such as the market for the types of information on purchasers that could help sellers to market products and services. This type of overlap would be much more difficult to cure by a minor divestiture. Whether the courts today would find such "relevant data markets" to exist is, however, a relatively untested possibility.

4. Indeed, in theory today it might even be possible for mergers to occur until five firms each controlled $20 \%$ of every market in the United States! For a general analysis of merger standards see Peter C. Carstensen \& Robert H. Lande, The Merger Incipiency Doctrine and the Importance of "Redundant" Competitors, 2018 WIS. L. REV. 783 (2018). 
Why did the antitrust laws permit the largest merger to date - the merger that combined Time Warner and AOL - in which the acquired company was valued at $\$ 164$ billion? ${ }^{5}$ Under the current interpretations of the antitrust laws, even the very largest corporations are free to merge so long as they operate in unrelated markets or compete only to a limited extent in related markets. Although the Congresses that enacted the anti-merger laws were motivated in part by the effects of corporate power on the political process, ${ }^{6}$ the federal antitrust agencies and courts today interpret these laws only in terms of economic effects within discrete markets. ${ }^{7}$ Unfortunately, existing anti-merger enforcement appears to be insufficient even using the limited neoclassical economic criteria of stopping mergers that raise prices, reduce output or choice, or lower quality or innovation. ${ }^{8}$ For the antitrust agencies, the considerations of political power, including the absolute size of the corporations involved, are irrelevant.

Senator Elizabeth Warren in 2019 proposed tighter merger restrictions on certain companies with more than $\$ 25$ billion in sales, ${ }^{9}$ and said: "We need to enforce our antitrust laws, break up these giant companies that are dominating big tech, big pharma, big oil, all of them." ${ }^{10}$ In 2017 , Senator

5. According to several sources, the biggest U.S. merger was America Online's acquisition of Time Warner in 2000. E.g., Henry Fernandez, The 10 Largest Corporate Mergers in U.S. History, Fox Business (June 13, 2018), https://www.foxbusiness.com/markets/the-10-largestcorporate-mergers-in-u-s-history [https://perma.cc/6898-JPSF]. The number reported by Fox Business was $\$ 164.75$ billion. Id.

6. See infra Part II.

7. See 15 U.S.C. $\S 18$ (2019). For a general analysis of how the mergers laws have been interpreted and implemented overall see Carstensen \& Lande, supra note 4.

8. See generally John Kwoka, Mergers, Merger Control, and Remedies: A Retrospective Analysis of U.S. Policy 148 (The MIT Press 2014).

9. Elizabeth Warren, Here's How We Can Break up Big Tech, Medium (Mar. 8, 2019), https://medium.com/@teamwarren/heres-how-we-can-break-up-big-tech-9ad9e0da324c

[https://perma.cc/8XK7-PX45] ("Companies with an annual global revenue of \$25 billion or more and that offer to the public an online marketplace, an exchange, or a platform for connecting third parties would be designated as 'platform utilities.' These companies would be prohibited from owning both the platform utility and any participants on that platform. . . I will appoint regulators who are committed to using existing tools to unwind anti-competitive mergers" from companies and those they own including: Amazon (Whole Foods and Zappos), Facebook (WhatsApp and Instagram), Google (Waze, Nest, and DoubleClick)).

10. See Ted Johnson, Democratic Candidates Differ on Ways To Rein in Facebook, Other Big Tech Firms, DeAdline (Oct. 15, 2019, 7:55 PM), https://deadline.com/2019/10/democraticdebate-facebook-elizabeth-warren-1202761256/ [https://perma.cc/UPF3-EXMU]. This alleged dominance was in part due to mergers. For example, Tim Wu noted: "In total, Facebook managed to string together 67 unchallenged acquisitions, which seems impressive, unless you consider that Amazon undertook 91 and Google got away with 214 (a few of which were conditioned)." TIM Wu, The Curse of Bigness: Antitrust in the New Gilded Age 123 (Columbia Global Reports 2018). 
Amy Klobuchar, together with three co-sponsors, introduced a Bill that would incorporate absolute size into merger analysis. ${ }^{11}$ These concerns follow a precedent set four decades ago by Senator Ted Kennedy when he introduced a bill that would have prevented any merger between firms that both exceeded roughly $\$ 7.5$ billion (in 2019 dollars) in assets, ${ }^{12}$ unless one of two exceptions applied. ${ }^{13}$ Its primary purpose was to help prevent increases in corporate political and social power. ${ }^{14}$ While libertarians may lament these bills as public or political incursions on private prerogatives, it is worth remembering that corporations are creatures of state action-endowed with special privileges such as limited liability and potential immortality through their charters. ${ }^{15}$ The public has the right to regulate institutions it created in the first place.

In recent years, popular concerns about corporate power, which formed much of the impetus behind the enactment of the existing antitrust laws, ${ }^{16}$ have reemerged. These public concerns include the political and social power ${ }^{17}$ possessed by the largest corporations. This apprehension has come from both the left and the right sides of the political spectrum. ${ }^{18}$

11. Senator Klobuchar introduced S. 1812 to tighten the merger laws in a number of ways. See Consolidation Prevention and Competition Promotion Act of 2017, S. 1812, 115th Cong. (2017). In particular, this Bill would mandate, for the first time, a more skeptical review of any acquisition of $\$ 5$ billion or more, or of any acquisition exceeding $\$ 50$ million by a firm with assets exceeding $\$ 100$ billion. Id. For these transactions, the legislation would switch the burden of proof and require that the merging firms prove that the acquisition will not be reasonably likely to lessen competition or tend to create a monopoly. Id.

12. See Michael Pertschuk \& Kenneth M. Davidson, What's Wrong with Conglomerate Mergers?, 48 Fordham L. REV. 1, 17-18 (1979) (discussing Proposed S. 600, Section 2(a)). This bill was designed to prevent clearly specified exceptionally large mergers. Id. A key requirement was that both corporations have more than \$2 billion in assets. Id. at 20. If \$2 billion in 1979 dollars is adjusted by the Consumer Price Index, it would be the equivalent of $\$ 7,443$ billion in March 2019 dollars. See CPI Inflation Calculator, BUREAU OF LABOR STATISTICS, https://data.bls.gov/cgi-bin/cpicalc.pl?cost1 =2\%2C000.00\&yearl=197901\&year2=201903 [https://perma.cc/7XSJ-PFTC].

13. Senator Kennedy's Bill contained an efficiencies defense. Pertschuk \& Davidson, supra note 12 , at 20 . It also contained the provision that these mergers could proceed even without efficiencies, but only if the combined entity sold or spun off sufficient assets so that its overall size did not increase due to the merger. Id. Because of this provision, this legislation was often referred to as the "Cap-And-Spinoff" approach to merger enforcement. Id. at 17.

14. Id.

15. Katharina Pistor, The Code of Capital: How the law Creates Wealth and INEQUALITY 47-76 (2019).

16. For examples of the populist suspicion of the political power of large businesses, see infra Part II.

17. An example of a relatively non-economic and non-political concern would be citizens' privacy concerns.

18. For examples from many different places on the political spectrum see infra Part III. 
Considering these developments, Congress should revisit and revive conglomerate merger legislation. ${ }^{19}$ This Article will propose model conglomerate merger legislation suitable for our era. This legislation should supplement existing merger law by targeting every merger that exceeds clearly specified asset thresholds, regardless of whether they involve direct competitors, firms in adjacent markets, or firms in unrelated industries. ${ }^{20}$

We are proposing a law that would block every merger in which both firms have assets exceeding \$10 billion, unless they spin-off assets so that their increase in size falls below this figure. ${ }^{21}$ This threshold would block at most ${ }^{22}$ approximately fifteen to twenty-five mergers each year. ${ }^{23}$ Reasonable approaches to the conglomerate merger problem could be stricter ${ }^{24}$ or looser. ${ }^{25}$ The goal of this Article is stimulate debate in this area.

This Article will undertake an updated legal, economic, and political analysis of conglomerate merger legislation. This analysis will demonstrate that our proposed legislation would: 1 . Produce no significant losses in the productive efficiency of corporations; 2 . Be clearer and more predictable than

19. See infra Part II.

20. This cap would apply to horizontal, vertical, and conglomerate mergers and would complement existing law restricting horizontal and vertical mergers. For instance, a horizontal merger may violate both the Clayton Act and the law we propose. The proposal, however, would have the most impact on large mergers that are purely conglomerate in nature and may not be illegal under current anti-merger law.

Our proposed legislation would only permit enforcement by the U.S. Department of Justice and the Federal Trade Commission. Congress could, of course, enact legislation that also allowed State and/or private enforcement.

21. This figure should be adjusted yearly to account for inflation.

22. Because our proposal would permit a merger to be consummated so long as the acquiring company spun off assets so that its overall size would increase by less than $\$ 10$ billion, many large "above $\$ 10$ billion" mergers could occur in large part. For example, suppose a $\$ 100$ billion firm purchased another firm for $\$ 14$ billion. So long as the acquiring company spun off any assets — whether from the acquired firm or the acquiring firm — that exceeding $\$ 4$ billion, the merger would not violate our proposal. We would expect this to happen in most cases involving acquisitions of less than $\$ 25$ billion. We would not be surprised if $\$ 25$ billion became the de facto threshold if our proposal were enacted.

23. See Appendix II.

24. For example, a $\$ 5$ billion or $\$ 1$ billion threshold could be used instead. Alternatively, the statute could focus upon the amounts of corporate sales, in addition to or instead of the amounts of corporate assets. Another possibility would be to block every merger by any firm with assets exceeding a clearly specified amount, such as $\$ 50$ billion. This approach would have many advantages, including clarity and simplicity. Nevertheless, it is not our preferred alternative because if a $\$ 50$ billion corporation purchased a company with assets of only $\$ 50$ million, this would not cause a significant increment in its political power.

25. Instead of a $\$ 10$ billion threshold, Congress might decide only to ban mergers where both corporations had assets exceeding a larger figure, such as the $\$ 25$ billion threshold suggested by Senator Warren, or even $\$ 50$ billion. See Warren, supra note 9 . A $\$ 50$ billion threshold should at most affect a handful of mergers per year. See Appendix II. 
the existing antitrust laws and thus will enhance the rule of law; and 3. Help prevent significant increases in corporate political power and other forms of non-economic power caused by corporate mergers.

\section{How Many Exceptionally Large Mergers ARE AtTempted AND How MANY ARE PREVENTED?}

With the caveats and uncertainties that are discussed in Appendix II, if our proposed legislation had been in effect, the following numbers of mergers might have been scrutinized and possibly blocked each year. The following figures are for the smaller of the two firms involved in transactions announced during individual years, in billions of dollars:

\begin{tabular}{|c|c|c|c|c|c|}
\hline & $\$ 100 \mathrm{~B}+$ & $\$ 75 \mathrm{~B}+$ & $\$ 50 \mathrm{~B}+$ & $\$ 25 \mathrm{~B}+$ & $\$ 10 \mathrm{~B}+$ \\
\hline 2019 & 0 & 1 & 7 & 13 & 24 \\
\hline 2018 & 0 & 0 & 1 & 6 & 16 \\
\hline 2017 & 1 & 1 & 3 & 6 & 14 \\
\hline 2016 & 1 & 3 & 4 & 7 & 14 \\
\hline 2015 & 2 & 3 & 8 & 14 & 24 \\
\hline Total & 4 & 8 & 23 & 46 & 92 \\
\hline
\end{tabular}

The current antitrust laws stop only a small percentage of these exceptionally large corporate mergers. With the caveats and uncertainties expressed in Appendix II, here is an overview of what happened to every merger from 2015-2019 in which both firms had assets of more than \$10 billion:

Forty-two unchallenged and permitted in full

Twenty-nine approved subject to spin offs and divestitures under U.S. antitrust law

Two approved subject to a conduct-oriented consent decree under U.S. antitrust law

Two challenged under U.S. antitrust law but eventually permitted in full

Two blocked by a U.S. court on antitrust grounds

One abandoned after U.S. antitrust challenge threatened or announced

Two blocked on non-antitrust grounds 
Three abandoned on non-antitrust grounds

Nine pending

Ninety-two total

There are many ways to characterize and interpret this data. For example, one could decide to exclude the mergers still pending and the mergers blocked or abandoned on non-antitrust grounds. If this were done, then only three out of seventy-eight of these mergers could be characterized as being completely stopped (blocked or abandoned) because of the U.S. antitrust laws.

\section{Why Do The CurRent Antitrust Laws Block So Few LARGE TRANSACTIONS?}

There is a simple answer to this question. The primary antitrust law that affects merger enforcement is the Clayton Act, which was written to prevent firms from acquiring rival companies or companies in a vertical relationship where "the effect of such acquisition may be substantially to lessen competition, or to tend to create a monopoly." ${ }^{26}$ Since the early 1980 s, the federal antitrust agencies have broken with Supreme Court precedent ${ }^{27}$ and

26. 15 U.S.C. $\S 18$ (West. 2019). Even though the existing anti-mergers law also apply to conglomerate mergers, the government only briefly enforced the law against those few conglomerate mergers that could be characterized as potential competition mergers, and only infrequently challenged vertical mergers. RudOLPH J. R. PERITZ, COMPETITION POLICY IN AMERICA, 1888-1992: History, RHETORIC, LAW 198 (1996). For a brief period in the 1960s through the early 1970s, the government successfully stopped some large conglomerate mergers on the basis of entrenchment, potential competition, and reciprocal dealing theories. E.g., FTC v. Procter \& Gamble Co., 386 U.S. 568 (1967); FTC v. Consolidated Foods Corp., 380 U.S. 592 (1965). The government has, in general, stopped litigating non-horizontal mergers. Before the 2017 government challenge to the vertical merger between AT\&T and Time Warner, the government last litigated a vertical merger to final judgment in 1979. Fruehauf Corp. v. FTC, 603 F.2d 345 (2d Cir. 1979).

27. In Brown Shoe Co. v. United States, the Supreme Court summarized the legislative intent animating the 1950 amendments to the Clayton Act. 370 U.S. 294, 315-16 (1962) ("The dominant theme pervading congressional consideration of the 1950 amendments was a fear of what was considered to be a rising tide of economic concentration in the American economy ... [and] [t]hroughout the recorded discussion may be found examples of Congress' fear not only of accelerated concentration of economic power on economic grounds, but also of the threat to other values a trend toward concentration was thought to pose."). 
reinterpreted the anti-merger statute to focus exclusively on mergers' effects on consumer welfare - an unsettled term. ${ }^{28}$

The current interpretation of the Clayton Act (and antitrust laws in general) does not explicitly include political or other considerations not tied to specific markets. ${ }^{29}$ Exceptionally large mergers may give rise to political or privacy concerns, but the agencies seek to block these mergers only if it's likely they will have substantial detrimental economic effects within clearly defined product and geographic markets. ${ }^{30}$ As Section I discussed, the enforcers and the courts have concluded that very few exceptionally large mergers would adversely affect consumer welfare in ways that cannot be prevented by conduct-oriented or structural remedies. ${ }^{31}$

In enacting the antitrust laws, Congress sought to, among other aims, restrict the social and political power of large corporations. The debates over the principal federal anti-merger statute focused on how corporate mergers led to increased corporate political power. ${ }^{32}$ During the 1914 Clayton Act

28. Consumer welfare is a very broad and controversial term. See Robert H. Lande, Wealth Transfers as the Original and Primary Concern of Antitrust: The Efficiency Interpretation Challenged, 34 Hastings L. J. 65 (1982) [hereinafter Lande, Wealth Transfers]. At its broadest it includes concerns with prices to consumers, the transfer of wealth from purchasers to firms with market power (aka the theft of consumers' surplus), quality, variety, and choice. See id.; Robert H. Lande, A Traditional and Textualist Analysis of the Goals of Antitrust: Efficiency, Preventing Theft from Consumers, and Consumer Choice, 81 FoRDHAM L. REV. 2349 (2013); see also Eleanor M. Fox, The 1982 Merger Guidelines: When Economists Are Kings?, 71 CALIF. L. REV. 281 (1983).

29. See Lande, Wealth Transfers, supra note 28, at 127-30. Of course, the mergers of exceptionally large corporations could give rise to numerous indirect externalities, both economic and non-economic, but these normally are not evaluated under the antitrust laws. In unusual cases, moreover, a merger could affect privacy enough to affect competition within a market. See Robert H. Lande, The Microsoft-Yahoo Merger: Yes, Privacy is an Antitrust Concern 1-2 (Univ. of Baltimore Legal Studies Research Paper No. 2008-06, FTC: Watch No. 714, 2008), https://papers.ssrn.com/sol3/papers.cfm?abstract_id=1121934 [https://perma.cc/XVX7-J4KS]. These cases could be evaluated using traditional antitrust tools.

30. See generally Carstensen \& Lande, supra note 4.

31. Of course, many of these decisions have been controversial, and would have been decided differently if they had been reviewed by different judges. See, for example, the decision in United States v. AT\&T Inc., which was upheld on appeal and denounced by the American Antitrust Institute. See United States v. AT\&T Inc., 310 F. Supp. $3 d 161$ (D.D.C. 2018); AAI Issues Statement on D.C. Circuit's Rejection of AT\&T/Time Warner Appeal, Says Time Is Ripe for Vertical Merger Guidelines and a Vertical "Presumption," AM. AnTITRUst InST., https://www.antitrustinstitute.org/aai-issues-statement-on-dc-circuits-rejection-of-att-timewarner-appeal-says-time-is-ripe-for-vertical-merger-guidelines-and-a-vertical-presumption/ [https://perma.cc/EF3T-3TD6].

32. This material has been adapted from Lande, Wealth Transfers, supra note 28, at 12730. 
debates, for example, one Representative condemned the discretionary political power of men like J.P. Morgan:

[A]11 of the power represented by this wealth is lodged in the hands of a few men. Can anyone doubt the danger which such concentration permits? . . . It is useless to say that the power represented will never be used to the detriment of the American people. . . . [I]t is too great a power to be concentrated-it affords too great a temptation to frail humanity. ${ }^{33}$

Congress also worried that the concentrated wealth and power of those who controlled large corporations could threaten the very fabric of the nation. The House Committee Report accompanying Section 8, which restricts interlocking directorships, warned that "[t]he concentration of wealth, money, and property in the United States under the control and in the hands of a few individuals or great corporations has grown to such an enormous extent that unless checked it will ultimately threaten the perpetuity of our institutions." ${ }^{, 34}$ Acknowledging the possibility that anti-merger legislation, in theory, might sacrifice productive efficiency, one Senator nevertheless strongly condemned monopolies and trusts because " $[\mathrm{t}]$ hey divide our people

33. 51 Cong. REC. 9186 (1914) (remarks of Rep. Helvering); see also id. at 14,536 (remarks of Senator Cummins).

34. H.R. ReP. No. 627, at 19, 63d Cong. (2d Sess. 1914); see also 51 Cong. ReC. 9086 (1914) (remarks of Rep. Kelly) ("Enterprises with great capital have deliberately sought not only industrial domination but political supremacy as well. . . . Great combinations of capital for many years have flaunted their power in the face of the citizenship, they have forced their corrupt way into politics and government, they have dictated the making of laws or scorned the laws they did not like, they have prevented the free and just administration of law. In doing this they have become a menace to free institutions and must be dealt with in patriotic spirit without fear or favor."). Representative Madden expressed the same concern, but in stronger language: "[T]he invisible Government which has controlled the visible government in this Nation for many years has been unscrupulous big business. . . . If this Nation is to be a Government of the people by crooked big business, the doom of our free institutions is assured." Id. at 9087. Representative Nelson used equally striking words:

As surely and rapidly as the properties of all the people pass into the hands of a few trust magnates, public sentiment, rapidly forming, when once fully aroused, will multiply the socialistic vote as a protest against monopoly privilege. And the day when the people must choose between public ownership of trusts for the benefit of all and the private ownership of the trusts for the privilege of the few, will witness the final triumph of socialism in this country. Therefore, we should act in our days of grace, while we are yet masters of our national destiny.

Id. at 9167. 
into classes, breed discontent and hatred, and in the end riot, bloodshed, and French revolutions." 35

Similarly, during the 1950 Celler-Kefauver Act debates, many members of Congress expressed striking misgivings regarding undue corporate aggrandizement of power. They cited the alarming consequences of concentration abroad. ${ }^{36}$ For example, Senator Kefauver, a leading sponsor of the bill, stated:

I am not an alarmist, but the history of what has taken place in other nations where mergers and concentrations have placed economic control in the hands of very few people is too clear to pass over easily. A point is eventually reached, and we are rapidly reaching that point in this country, where the public steps in to take over when concentration and monopoly gain too much power. The taking over by the public through its government always follows one or two methods and has one or two political results. It either results in a Fascist state or the nationalization of industries and thereafter a Socialist or Communist state. ${ }^{37}$

It is perhaps ironic that the antitrust laws, under present interpretation, cannot prevent some extremely large mergers that could lead to the very types of political and social problems that motivated the enactment of these laws. A few scholars have argued that the Clayton and FTC Acts can be used to stop pure conglomerate mergers on the basis of size alone. ${ }^{38}$ Under the

35. 51 Cong. Rec. 15,955 (1914) (remarks of Sen. Borah).

36. 95 ConG. REC. 11,486 (1949) (remarks of Rep. Celler) ("I want to point out the danger of this trend toward more and better combines. I read from a report filed with former Secretary of War Royall as to the history of the cartelization and concentration of industry in Germany: 'Germany under the Nazi set-up built up a great series of industrial monopolies in steel, rubber, coal and other materials. The monopolies soon got control of Germany, brought Hitler to power and forced virtually the whole world into war."'). It should be noted that Representative Celler's interpretation of the historical events which led to Hitler's rise to power is by no means universally shared. See, e.g., Alan Bullock, Hitler: A StUdy In TyRAnNy (1962).

37. 96 CONG. REC. 16,452 (1950) (remarks of Sen. Kefauver). These strong views were not expressed only by the principal sponsors of the amendment. See, e.g., id. at 16,446 (remarks of Sen. O'Mahoney) ("Collectivism is moving forward apace throughout the world, and industrial collectivism leads inevitably to political collectivism. That I would like to avoid."). See id. at 16,503-04 (remarks of Sen. Aiken) ("All of us know too well what has happened in countries where opportunity has been vested in the hands of a few. The result has been that either socialization or a totalitarian form of government has taken over . ...").

38. See Peter C. Carstensen \& Nina H. Questal, Use of Section 5 of the Federal Trade Commission Act To Attack Large Conglomerate Mergers, 63 CORNELL L. REV. 841, 841-42 (1978) ("This Article will demonstrate that section 5 of the Federal Trade Commission Act, in light of its legislative history and evolving Supreme Court interpretation, is an appropriate mechanism for dealing with conglomerate mergers."); Harlan M. Blake, Conglomerate Mergers 
dominant view of antitrust today, however, conglomerate mergers - indeed nearly all mergers of any kind - are treated as competitively benign and legal under the antitrust laws. ${ }^{39}$ Our proposed legislation would thus revisit and restore the progressive-populist aims of antitrust. This time, however, these concerns would be enacted expressly into law and not be susceptible to administrative and judicial reinterpretation. ${ }^{40}$

\section{The LARgest Mergers Lead to CORPORATE POWER THAT CONCERNS MANy PEOPLE IN VirTUAlly EVERy PART OF THE POLITICAL SPECTRUM}

Corporate size often translates to political power. An extensive body of research has found that firm size is correlated with more political activity. ${ }^{41}$ Larger firms make larger contributions to political campaigns and devote more resources to lobbying members of Congress and government agencies. ${ }^{42}$

and the Antitrust Laws, 73 COLUM. L. REv. 555, 570 (1973) ("But the antitrust laws, including section 7 , have since their beginnings been directed towards an even more fundamental objective: the prevention of the destruction or erosion of the competitive system, a form economic organization in which economic power in any form should not be permitted to limit the freedom of equally efficient smaller entrepreneurs to compete, on fair and equal terms, with larger firms or groupings of firms; and the avoidance of the political consequences of such an impairment of the traditional system.").

39. Professor John Kwoka has documented a steady decline in enforcement against even horizontal mergers in concentrated markets. John Kwoka, The Structural Presumption and the Safe Harbor in Merger Review: False Positives or Unwarranted Concerns?, 81 ANTITRUST L.J. 837, 867 (2017).

40. Consider the radically different interpretations of the Sherman Act over time. Its openended text gives enforcers and judges broad power to reinterpret it. In 1958, the Supreme Court described the Sherman Act as

a comprehensive charter of economic liberty aimed at preserving free and unfettered competition as the rule of trade. It rests on the premise that the unrestrained interaction of competitive forces will yield the best allocation of our economic resources, the lowest prices, the highest quality and the greatest material progress, while at the same time providing an environment conductive to the preservation of our democratic political and social institutions.

N. Pac. Ry. Co. v. United States, 356 U.S. 1, 4 (1958). Two decades later, despite no revision to the statute, the Court, following a substantial change in its composition, stated that the Sherman Act is a "consumer welfare prescription." Reiter v. Sonotone Corp., 442 U.S. 330, 343 (1979) (quoting Robert H. Bork, The Antitrust Paradox 66 (1978)).

41. See, e.g., Martin Gilens \& Benjamin I. Page, Testing Theories of American Politics: Elites, Interest Groups, and Average Citizens, 12 PERSPS. ON POL. 564 (2014); Lester M. Salamon \& John J. Siegfried, Economic Power and Political Influence: The Impact of Industry Structure on Public Policy, 71 The Am. Pol. ScI. Rev. 1026, 1031 (1977).

42. Gilens \& Page, supra note 41; Salamon \& Siegfried, supra note 41. 
Judicial reinterpretations of the First Amendment have granted corporate political activity broad constitutional protection. ${ }^{43}$ Their power is not confined to these "narrow" political activities. Large businesses also use their wealth power to fund sympathetic media coverage and scholarly research. This corporate political activity benefits executives and shareholders at the expense of the rest of society.

Corporate power in politics and public life is not an academic concern and today attracts critics from across much of the political spectrum. ${ }^{44} \mathrm{~A}$ large segment of the public is deeply concerned about corporate clout and influence in American politics. From the progressive left to the nationalist or conservative right, many individuals and organizations have expressed worries about powerful corporations capturing the political system and using it to advance their narrow aims. An ideologically diverse set of figures and groups have raised concerns about the political power of large corporations and started offering remedies.

\section{A. Corporate Size Translates to Political and Economic Power}

Corporate size often translates to political and economic power. An extensive body of research has found that firm size is correlated with political activity. ${ }^{45}$ Larger firms make larger contributions to political campaigns and other activities and devote more resources to lobbying members of Congress and government agencies. ${ }^{46}$ They can also use their power to fund sympathetic media coverage and scholarly research. ${ }^{47}$ This corporate political activity has tangible benefits for executives and shareholders. An influential 2014 study found that members of Congress in voting on bills are responsive to the views of two groups: large businesses and the wealthy. ${ }^{48}$ In contrast,

43. Consider the Supreme Court's invalidation of federal restrictions on the use of general corporate funds for political activity. Citizens United v. Fed. Election Comm'n, 558 U.S. 310 (2010). The Supreme Court has also immunized anticompetitive and other unfair corporate petitioning of government from antitrust liability. E. R.R. Presidents' Conference v. Noerr Motor Freight, Inc., 365 U.S. 127 (1961); United Mine Workers of Am. v. Pennington, 381 U.S. 657 (1965).

44. The connection between corporate size and corporate political power has long animated antimonopoly champions. See, e.g., Louis D. BrandeIs, The Curse of Bigness: Miscellaneous PaPers of Louis D. Brandeis, 18 (Osmond K. Fraenkel ed., 1935).

45. See, e.g., Gilens \& Page, supra note 41; Salamon \& Siegfried, supra note 41.

46. Gilens \& Page, supra note 41; Salamon \& Siegfried, supra note 41.

47. Matthew A. Baum \& Yuri M. Zhukov, Media Ownership and News Coverage of International Conflict, 31 PoL. CoMM. 36 (2019); Alice Fabbri et al., The Influence of Industry Sponsorship on the Research Agenda: A Scoping Review, 108 AM. J. Pub. HeAlth e9 (2018).

48. Gilens \& Page, supra note 41. 
they are largely indifferent to the political concerns and preferences of the middle and working classes. ${ }^{49}$

Large firms exercise political power through campaign contributions. An extensive body of empirical literature has found that large firms make larger campaign contributions to members of Congress and political action committees than small firms do ${ }^{50}$ Campaign contributions are an important way to build and maintain political influence. While the findings on the question are mixed, campaign contributions may increase the likelihood that the member's votes and other actions are aligned with the donor's interests. ${ }^{51}$

Political contributions can give corporate donors access to those in power. Lending credence to what research had found, ${ }^{52}$ Mick Mulvaney, the current director of the Office of Management and Budget and former acting director of the Consumer Financial Protection Bureau, openly admitted this dynamic in a speech before bank lobbyists. ${ }^{53}$ He stated that, as a member of Congress, he granted preferential access to lobbyists who had donated to his political campaigns. $^{54}$

Large firms also wield political power through lobbying, an arguably much more important form of political activity than political contributions. ${ }^{55}$ They often have large staffs of lawyers and lobbyists to present their messages to politicians and regulators. ${ }^{56}$ Relative to smaller firms, large firms devote more resources to lobbying activity. ${ }^{57}$ This lobbying allows

49. $I d$.

50. Wendy L. Hansen \& Neil J. Mitchell, Disaggregating and Explaining Corporate Political Activity: Domestic and Foreign Corporations in National Politics, 94 AM. PoL. ScI. REv. 891 (2000); David M. Hart, Why Do Some Firms Give? Why Do Some Give a Lot? High-Tech PACs, 1977-1996, 63 J. PoL. 1230 (2001).

51. Matthew D. Hill, G. Wayne Kelly \& G. Brandon Lockhart, Determinants and Effects of Corporate Lobbying, 42 FIN. MGMT. 931, 954 (2013).

52. Id.

53. Renae Merle, Mulvaney Discloses 'Hierarchy' for Meeting Lobbyists, Saying Some Would Be Seen Only if They Paid, WASH. Post (Apr. 25, 2018), https://www.washingtonpost.com/news/business/wp/2018/04/25/mick-mulvaney-facesbacklash-after-telling-bankers-if-you-were-a-lobbyist-who-never-gave-us-money-i-didnt-talkto-you/?utm_term=.12cae2d4ac30 [https://perma.cc/AF8W-G9HL].

54. Id.

55. Hui Chen, David C. Parsley \& Ya-Wen Yang, Corporate Lobbying and Financial Performance (Oct. 2014), https://papers.ssrn.com/sol3/papers.cfm?abstract_id=1014264 [https://perma.cc/GH9L-WA52].

56. See, e.g., Jade Scipioni, Amazon Is Now the Biggest Corporate Lobbyist in Washington, Fox Business (Oct. 16, 2017), https://www.foxbusiness.com/features/amazon-is-now-thebiggest-corporate-lobbyist-in-washington [https://perma.cc/S5T6-HTAU].

57. Richard Borghesi \& Kiyoung Chang, The Determinants of Effective Corporate Lobbying, 39 J. ECON. \& FIN. 606, 615 (2015); William R. Kerr, William F. Lincoln \& Prachi Mishra, The Dynamics of Firm Lobbying, 6 AM. ECON. J.: ECON. POLICY 343, 346 (2014). 
corporations to shape the narrative around an issue and influence members of Congress and regulators. Lobbying is often an effective strategy for casting doubt on the public benefits of legislation and regulation. ${ }^{58}$ Corporate lobbyists can create counter-narratives that proposed legislation restricting their client's activities would either not advance or undermine the public interest. ${ }^{59}$ For instance, despite triggering the worst economic crisis in nearly eighty years, large banks and financial institutions in the United States, through all-encompassing lobbying and public relations blitz, subsequently avoided structural breakups and significant restrictions on their activity. ${ }^{60}$

Indeed, the present weak enforcement of antitrust may, in part, be a product of corporate power and influence over the federal antitrust agencies. ${ }^{61}$ "Regulatory capture" occurs when a regulatory agency or enforcer is so greatly influenced by businesses that it fails to act in the public's interest. ${ }^{62}$ Instead it acts in ways that benefits the players in the industry that the regulators were charged with policing. ${ }^{63}$ One possible cause of regulatory capture is that the agency often has limited resources compared to the regulated companies. ${ }^{64}$ When the regulated business is a multi-billion-dollar company, the disparity in resources can be especially large and regulatory capture becomes more probable. ${ }^{65}$

58. Michael Hadani, Jean-Philippe Bonardi \& Nicolas M. Dahan, Corporate Political Activity, Policy Uncertainty, and Firm Outcomes: A Meta-Analysis, 15 Strategic Org. 338 (2017).

59. See generally Albert O. Hirschman, The Rhetoric of Reaction: Perversity, FUtility, JEOPARDY (1991). Moreover, there sometimes is said to be an "iron triangle" of Congress, industry and the federal government. See Paul M. Johnson, A Glossary of Political Economy Terms: Iron Triangles, AUBURN UnIV. (2015), http://www.auburn.edu/ johnspm/gloss/iron_triangles__https://perma.cc/Z9M7-PZBU]. The federal government gives out a lot of special interest favors to Congressmen, and the bureaucrats, especially the higher-ups, go along, often in order to set themselves up for after they leave government service. $I d$. Lobbying occurs across industry and market lines, and conglomerate mergers can help produce a united front against reformers asking for accountability of government policies. $I d$.

60. See generally Arthur E. Wilmarth Jr., Turning a Blind Eye: Why Washington Keeps Giving in to Wall Street, 81 U. CIN. L. REV. 1283 (2012).

61. See Will Kenton, Regulatory Capture, InvestopediA (Oct. 23, 2019), https://www.investopedia.com/terms/r/regulatory-capture.asp [https://perma.cc/5SUR-AHG4].

62. Id.; see also Cary Coglianese, The Elusiveness of Regulatory Capture, The Regulatory Review (July 5, 2016), https://www.theregreview.org/2016/07/05/coglianese-the-elusiveness-ofregulatory-capture/ [https://perma.cc/LEZ6-3G7L].

63. Kenton, supra note 61.

64. Tejvan Pettinger, Regulatory Capture, Econ. Help (May 24, 2018), https://www.economicshelp.org/blog/141040/economics/regulatory-capture/ [https://perma.cc/SCR6-4WQR].

65. See generally id. 
The FTC and DOJ's reluctance and unwillingness to challenge some huge mergers could, in part, be caused by the considerable influence massive companies have over them and the political environment in which they operate. For instance, FTC Commissioner Rohit Chopra recently voiced concern over the power of big tech in a trade regulation context, stating: "All too often, the government is too captured by those incumbents that use their power to dictate their preferred policies." Consistent with the "capture" theory, mergers can produce large companies with substantial resources to hire the requisite numbers of lawyers, lobbyists, and experts to "capture" a regulatory agency or enforcer.

The power of large corporations extends beyond the political, regulatory, and legal realms. Their power can be characterized as hegemonic. They can shape the parameters of public debate through a variety of means. They use their advertising dollars to boost supportive outlets and voices and marginalize critical ones ${ }^{67}$ - and even co-opt individual and organizational voices that are conventionally perceived as progressive. ${ }^{68}$ They also own media outlets (think of Amazon founder Jeff Bezos and his ownership of the Washington Post) and fund think tanks that can propagate their preferred narrative on a range of issues. ${ }^{69}$ Big businesses have also become adept at manipulating academic debates to their own ends, donating to universities, sponsoring new academic centers, and paying ideologically-aligned scholars to produce academic defenses. ${ }^{70}$ Indeed, present-day antitrust embodies the

66. U.S. Rohit Chopra Is Concerned that the Government Is "Captured" by Big Tech, COMPETITION POL'Y INT'L (Oct. 20, 2019), https://www.competitionpolicyinternational.com/usrohit-chopra-is-concerned-that-the-government-is-captured-by-bigtech/?utm_source $=\mathrm{CPI}+$ Subscribers\&utm_campaign $=859 \mathrm{f0} 4 \mathrm{cdab}-$

EMAIL_CAMPAIGN_2019_10_17_09_35_COPY_01\&utm_medium =email\&utm_term=0_0e a61134a5-859f04cdab-234822917 [https://perma.cc/E2ZD-87ZS].

67. See Soontae An \& Lori Bergen, Advertiser Pressure on Daily Newspapers: A Survey of Advertising Sales Executives, 36 J. ADVER. 111 (2007).

68. See Lee Fang, Civil Rights Groups, Funded by Telecoms, Back Donald Trump's Plan To Kill Net Neutrality, THE INTERCEPT (Feb. 13, 2017), https://theintercept.com/2017/02/13/naacp-trump-netneutrality/ [https://perma.cc/3NYS-3Z4Z]; Editorial, How to Promote a Merger, N.Y. Times (July 8, 2011), https://www.nytimes.com/2011/07/09/opinion/09sat2.html [https://perma.cc/GL3U-ZMJE].

69. Eric Lipton \& Brooke Williams, How Think Tanks Amplify Corporate America's Influence, N.Y. TIMES (Aug. 7, 2016), https://www.nytimes.com/2016/08/08/us/politics/thinktanks-research-and-corporate-lobbying.html [https://perma.cc/CPB3-YL6E].

70. Lee Fang, The Scholars Who Shill for Wall Street, ThE NATION (Oct. 23, 2013), https://www.thenation.com/article/scholars-who-shill-wall-street/ [https://perma.cc/G8RXU29L]; Erica L. Green \& Stephanie Saul, What Charles Koch and Other Donors to George Mason University Got for Their Money, N.Y. Times (May 5, 2018), https://www.nytimes.com/2018/05/05/us/koch-donors-george-mason.html [https://perma.cc/7WGV-H3E2]. 
extraordinary influence of corporations. Over the past several decades, corporate-funded economists and lawyers have played an outsized role in antitrust debates. $^{71}$

Furthermore, corporate size confers power through the control of economic resources. At a large corporation, a handful of individualsexecutives and directors - make decisions that affect entire cities, regions, and even the nation. A decision to open a plant in one city, instead of another, or to relocate a plant from the United States to a foreign country can affect large numbers of people. Senator Sherman recognized how concentration of assets in a few hands amounted to private government. ${ }^{72} \mathrm{He}$ asked his colleagues to "consider ... whether, on the whole, it is safe in this country to leave the production of property, the transportation of our whole country, to depend upon the will of a few men sitting at their council board in the city of New York." 73

Corporate size means that every nominally private decision has major public implications. ${ }^{74}$ They can use their control of key resources to stop unfavorable government action and induce favorable action. ${ }^{75}$

Consider the recent contest among states and cities to host Amazon's second headquarters. Amazon invited state and local governments across the country to compete for this second headquarters in exchange for a pledge to create 50,000 local jobs. ${ }^{76}$ States and cities showered Amazon with a range

\footnotetext{
71. Jesse Eisinger \& Justin Elliott, These Professors Make More Than a Thousand Bucks an Hour Peddling Mega-Mergers, ProPublicA (Nov. 16, 2016), https://www.propublica.org/article/these-professors-make-more-than-thousand-bucks-hourpeddling-mega-mergers [https://perma.cc/FWF8-QXQZ]; STEVEN TELES, THE RiSE OF THE Conservative Legal Movement: The Battle for Control of the LAW 85-92 (2008) (documenting Henry Manne's success in raising money from large corporations to build the law and economics movement and help challenge then-prevailing thinking on antitrust law). For a documentation of the effects of the law and economics movement on judicial decision-making, see generally Elliott Ash, Daniel L. Chen \& Suresh Naidu, Ideas Have Consequences: The Effect of Law and Economics on American Justice (June 26, 2017), https://papers.ssrn.com/sol3/papers.cfm?abstract_id=2992782 [https://perma.cc/7BXT-NPKH].

72. 21 Cong. Rec. 2570 (1890).

73. Id.

74. See generally James W. Brock, Economic Concentration and Economic Power: John Flynn and a Quarter-Century of Mergers, 56 AnTITRUST Bull. 681 (2011).

75. Id. at 728 .

76. Kim Hjelmgaard, Mike Snider \& Elizabeth Weise, Amazon To Add Second Headquarters with up to 50,000 Jobs in Grab for Talent, USA TODAY (Sept. 7, 2017, 7:47 PM), https:/www.usatoday.com/story/money/2017/09/07/amazon-plans-second-headquartersdubbed-hq-2/640861001/ [https://perma.cc/WK5J-NJP8].
} 
of carrots amounting to billions of dollars in tax incentives. ${ }^{77}$ Exemplifying the lengths to which governments were willing to go to lure Amazon, New York Governor Andrew Cuomo (half-) jokingly even offered to change his first name to Amazon if Amazon chose New York City. ${ }^{78}$ This frenzied competition illustrates the power of a large corporation over democratically elected governments. And this episode is not an outlier but representative of how large corporations use their power and the threat of relocation to pressure and twist governments for their own ends. ${ }^{79}$

\section{B. Growing Political and Public Concern About Corporate Power}

Public recognition of, and concern about, corporate political power is growing. An increasing number of politicians and public figures are focused on the political and social - as well as economic - power of large businesses. This concern is not limited to one portion of the political spectrum. A diverse set of voices and organizations are calling for tackling monopoly and oligopoly power in American society.

Prominent liberal and progressive voices have demanded action to curb the economic and political power of large corporations. Many Democrats have made strengthening anti-merger and anti-monopoly law a key pillar of

77. Spencer Soper, Amazon Is Under Attack for Seeking Tax Break in Exchange for HQ2, BloOMBERG (Sept. 7, 2018, 3:00 AM), https://www.bloomberg.com/news/articles/2018-0907/amazon-s-headquarters-bake-off-puts-it-in-corporate-welfare-spotlight [https://perma.cc/F48X-32M9].

78. Karen Weise \& J. David Goodman, Amazon Plans to Split HQ2 Between Long Island City, N.Y., and Arlington, Va., N.Y. TimeS (Nov. 5, 2018), https://www.nytimes.com/2018/11/05/technology/amazon-second-headquarters-split.html [https://perma.cc/GV4Y-CMJN].

79. John Browne, the former CEO of BP, described this dynamic in an interview with The Wall Street Journal.

We do get the seat at the table because of our scope and size, whether we are the second or the third largest [oil] company is of very little import, but we're certainly up there and we operate in places which are important to the United States government, and the United States government is important to us. We have large numbers of employees in the United States. That's very important in a political system. And they are highly concentrated. So we have a very significant presence in Texas, Illinois, Alaska, and California. These are important because our employees are voters.

BP Won't Abandon Driving Force, Interview with John Browne, Wall St. J. (Nov. 25, 2003). For an in-depth analysis of one company's domestic and international mobility, see generally JefFerson Cowie, CAPITAl Moves: RCA’s SEventy-Year QUeSt For CheAP LABOr (2001). 
their agenda. ${ }^{80}$ As mentioned in the introduction, Senator Amy Klobuchar introduced an anti-merger bill that would establish a presumption of illegality involving mergers that combined more than $\$ 5$ billion in assets. ${ }^{81}$ This bill would target corporate size directly, although it features a large exemption for pure conglomerate mergers. ${ }^{82}$

Senator Bernie Sanders weighed in against the AT\&T/Time Warner merger and identified the further agglomeration of power as a principal evil of the combination. ${ }^{83} \mathrm{He}$ stated this consolidation "represents a gross concentration of power that runs counter to the public good." ${ }^{\prime 4}$ And in early October 2018, Sanders introduced a bill that would break up the largest financial institutions in the United States and establish a cap on size going forward. ${ }^{85}$ Senator Sanders also promised to combat the excesses of large firms in the agricultural sector, stating that they are devastating to the small farmer and are a direct cause of mass unemployment, lower wages, massive wealth inequality, and a host of social problems. ${ }^{86}$ In his October 2019 Corporate Accountability and Democracy plan, presidential candidate

80. Matthew Yglesias, Democrats' Push for a New Era of Antitrust Enforcement, Explained, Vox (Jul. 31, 2017, 8:00 AM), https://www.vox.com/policy-andpolitics/2017/7/31/16021844/antitrust-better-deal [https://perma.cc/H8ZD-DN85].

81. See S. 1812, 116th Cong. (2017).

82. Id. Under this bill, the merging parties could overcome the presumption of illegality if they can show, "by a preponderance of the evidence, that the effect of the acquisition will not be to tend to materially lessen competition or tend to create a monopoly or a monopsony." Id. $\S 3$. This would ensure that pure conglomerate mergers could be pursued, largely unchecked.

83. Bernie Sanders (@SenSanders), TwitTer (Oct. 23, 2016, 2:03 PM), https://twitter.com/SenSanders/status/790297619788685316 [https://perma.cc/5G7U-6LLG].

84. Bernie Sanders (@SenSanders), TwitTer (June 12, 2018, 4:49 PM), https://witter.com/sensanders/status/1006684905554706438?lang=en [https://perma.cc/8ZTD-QYBL].

85. Press Release, Bernie Sanders, Sanders, Sherman Introduce Legislation To Break Up Too Big To Fail Financial Institutions (Oct. 3, 2018), https://www.sanders.senate.gov/newsroom/press-releases/sanders-sherman-introducelegislation-to-break-up-too-big-to-fail-financial-institutions [https://perma.cc/PZ3F-LCC7].

86. Bernie Sanders, Opinion, Bernie Sanders: I'll Fight for Farmers Against Powerful Agribusiness, Des MoInes REg. (Mar. 28, 2019, 11:06 AM), https:/www.desmoinesregister.com/story/opinion/columnists/caucus/2019/03/28/berniesanders-president-2020-caucus-agribusiness-factory-farming-rural-america-iowa-flood-trumpceo/3297096002/ [https://perma.cc/5L3D-WWBJ] ("When we are in the White House, we are going to strengthen antitrust laws that defend farmers from the corporate middlemen that stand between the food grower and the consumer, and have now become so big and powerful that they can squeeze farmers for everything they're worth. We must end the absurd situation where the top four packing companies now control more than 80 percent of the beef market, 63 percent of the pork market, and 53 percent of the chicken market. We must help communities where there is a single buyer, meaning farmers are at the mercy of a corporation that's effectively forcing them to use only the company's feed and livestock."). 
Sanders condemned the present system in which "a small group of ultrawealthy CEOs are making the decisions that increasingly determine our economic, environmental and political future." ${ }^{87}$

Senator Elizabeth Warren has offered extensive critiques of corporate power, citing undue political influence as one of the evils of corporate bigness. ${ }^{88}$ In a keynote address at a conference hosted by the Open Markets Institute in December 2017, Senator Warren warned that "[c]oncentrated market power also translates into concentrated political power-the kind of power that can capture our government. And that's exactly what's happening, as President Trump and the Republicans in Congress bow to the power and influence of these industrial giants and financial titans." ${ }^{\circ 9}$ Warren promised that if elected president, she would break up Amazon, Facebook, and Google. ${ }^{90}$ She published a detailed plan to break up big tech companies, including the creation of a threshold of $\$ 25$ billion in annual revenue, above which companies would be subject to restrictions and regulations including mandatory divestitures of certain portions of the company. ${ }^{91}$ Facebook allegedly removed Warren's political ads posted on Facebook that called for breaking up Facebook. ${ }^{92}$

Warren also called for breaking up some of the biggest farming corporations "so that they not only do not have that kind of economic power,

87. Bernie Sanders, Corporate Accountability and Democracy, BERNIE 2020, https://berniesanders.com/issues/corporate-accountability-and-democracy/ [https://perma.cc/UXF8-TGBA].

88. Elizabeth Warren, Opinion, Three Ways To Remake the American Economy for All,

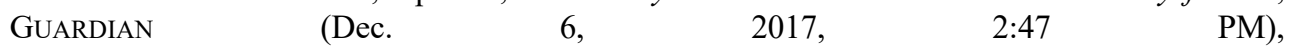
https://www.theguardian.com/commentisfree/2017/dec/06/elizabeth-warren-monopoliesamerican-economy [https://perma.cc/MGS4-PVVC].

89. Id.

90. Sean Moran, Elizabeth Warren Proposes Breaking Up Amazon, Facebook, Google, BREITBART (Mar. 8, 2019), https://www.breitbart.com/politics/2019/03/08/elizabeth-warrenproposes-breaking-up-amazon-facebook-google/ [https://perma.cc/52WY-TTQG].

91. Warren, supra note 9 ("To restore the balance of power in our democracy, to promote competition, and to ensure that the next generation of technology innovation is as vibrant as the last, it's time to break up our biggest tech companies.").

92. Sanjana Karanth, Facebook Temporarily Removed Elizabeth Warren Ads Urging Breakup of Tech Giants, Huffington Post (Mar. 12, 2019), https://www.huffpost.com/entry/elizabeth-warren-facebookads_n_5c86fbb4e4b08d5b7864b594 [https://perma.cc/35LC-FD6W] ("Curious why I think FB has too much power? Let's start with their ability to shut down a debate over whether FB has too much power. Thanks for restoring my posts. But I want a social media marketplace that isn't dominated by a single censor."). 
so that they're wiping out competition, so they're taking all the profits for themselves . . . but also so that they don't have that kind of political power." 93

These figures are not outliers but are representative of a growing antimonopoly philosophy among Democrats, liberals, and progressives. Others have echoed the concerns expressed by Senators Klobuchar, Sanders, and Warren. (Former) Representative (and current Minnesota Attorney General) Keith Ellison and sitting Representative Ro Khanna established an Antitrust Caucus and called for antitrust enforcers to look beyond just consumer welfare. ${ }^{94}$ Alexandria Ocasio-Cortez, the Democratic representative for New York's 14th Congressional district, has repeatedly voiced concerns about the political might of large financial institutions. ${ }^{95}$ Senator Cory Booker has lamented the "incredible concentration of economic and political power in this country" ${ }^{96}$ and introduced a bill that would establish a moratorium on corporate mergers in agriculture. ${ }^{97}$ Former Colorado governor and former presidential candidate John Hickenlooper has called for a major revival in antimonopoly enforcement. ${ }^{98}$

Indeed, many Democrats have criticized the political power of banks since at least the 2007-08 financial crisis. In early 2009, just six months after the collapse of Lehman Brothers and the start of the worst financial crisis in eighty years, Senator Richard Durbin famously observed that "the bankshard to believe in a time when we're facing a banking crisis that many of the

93. Alexandra Jaffe, Elizabeth Warren and Amy Klobuchar Both Agree on Breaking Up 'Big Agriculture' Monopolies, Business INSIDER (Mar. 30, 2019, 7:22 PM), https:/www.businessinsider.com/warren-klobuchar-agree-on-breaking-up-big-ag-2019-3 [https://perma.cc/V2DQ-33LN].

94. Tess Townsend, Keith Ellison and the New 'Antitrust Caucus' Want To Know Exactly How Bad Mergers Have Been for the American Public, N.Y. MAG. (Dec. 4, 2017), http://nymag.com/selectall/2017/12/antitrust-bill-from-keith-ellison-seek-info-on-mergers.html [https://perma.cc/2A82-HJ9P].

95. Alexandria Ocasio-Cortez, Curb Wall Street Gambling: Restore Glass Steagall, OCASIO2018.COM, https://ocasio2018.com/issues [https://perma.cc/NS6S-W8DJ].

96. Open Market Inst., Remarks by Senator Cory Booker at "A Right to Compete: Are Monopolies Crushing Entrepreneurship?”, YouTuBE (Oct. 12, 2018), https:/www.youtube.com/watch?list=PL17VSnPfVKIgkUpV_vGIcZrZAJETwdovs\&v=kLR9tZ Qyk30\&feature=emb_logo [https://perma.cc/XV9Z-Y59W].

97. Press Release, Cory Booker, Booker Introduces Bill To Place Moratorium on Ag Mergers (Aug. 29, 2018), https://www.booker.senate.gov/?p=press_release\&id=844 [https://perma.cc/N7U5-TZZ7].

98. John Hickenlooper, John Hickenlooper: Leveling the Playing Field for Small Businesses, MEDIUM (Apr. 25, 2019), https://medium.com/@johnhickenlooper/johnhickenlooper-leveling-the-playing-field-for-small-businesses-467fd6c3ece [https://perma.cc/272J-LAJ2]. 
banks created - are still the most powerful lobby on Capitol Hill. And they frankly own the place." 99

Among academics and commentators, Joseph Stiglitz and Paul Krugman have repeatedly sounded the alarm about the pervasive market power problem. Stiglitz has opined that "America has a monopoly problem-and it's huge" and cited the political power of large corporations as subverting democracy. ${ }^{100}$ Krugman has similarly recognized the corrosive political power of large corporations. ${ }^{101}$ Former Secretary of Labor, Harvard professor, and political commentator Robert Reich applauded Elizabeth Warren's announced intention to break up big tech and predicted that breaking them up would allow for more privacy, decentralization of information, and more innovation. ${ }^{102}$ Barry Lynn, director of the Open Markets Institute think tank, has sounded the alarm that tech giants like Google and Facebook are a threat to core democratic institutions. ${ }^{103}$ Zephyr Teachout, a progressive law professor, promised that if elected Attorney General of New York she would explore breaking up Google and Facebook using New York state antitrust laws. ${ }^{104}$

\footnotetext{
99. Ryan Grim, Dick Durbin: Banks "Frankly Own the Place”, Huffington Post (May 25, 2011), https://www.huffingtonpost.com/2009/04/29/dick-durbin-banksfrankly_n_193010.html [https://perma.cc/FAV3-28HV].

100. Joseph E. Stiglitz, America Has a Monopoly Problem — and It's Huge, NATION (Oct. 23, 2017) https:/www.thenation.com/article/america-has-a-monopoly-problem-and-its-huge/ [https://perma.cc/99YF-JNL8].

101. Paul Krugman, Challenging the Oligarchy, N.Y. REV. BooKs (Dec. 17, 2015), https://www.nybooks.com/articles/2015/12/17/robert-reich-challenging-oligarchy/ [https://perma.cc/P67B-78F7].

102. Robert Reich, Elizabeth Warren Is Right-We Must Break Up Facebook, Google and Amazon, GUARDIAN (Mar. 10, 2019, 1:00 https://www.theguardian.com/commentisfree/2019/mar/09/elizabeth-warren-break-up-

facebook-google-amazon [https://perma.cc/N9AJ-5BDW] ("Like the robber barons of the first Gilded Age, those of the second have amassed fortunes that gave them unparalleled influence over politicians and the economy.").

103. Russell Brandom, The Anti-Monopoly Case Against Google: A Conversation with Open Markets' Barry Lynn, VERGE (Sept. 5, 2017, 2:55 PM), https://www.theverge.com/2017/9/5/16243868/google-monopoly-antitrust-open-markets-barrylynn [https://perma.cc/NX35-DBJH] ("It's important to talk about monopoly power in general because monopolies are a threat to our democracy and to our basic liberties and to our communities. Monopolization, this concentration of wealth and power, is a threat to everything that is America - everything we established America to ensure.").

104. Brian Fung, Time To Break Up Google and Facebook, Says New York Attorney General Candidate, WASH. POST (July 25, 2018, 12:07 PM), https:/www.washingtonpost.com/technology/2018/07/25/time-break-up-google-facebook-saysnew-york-attorney-general-candidate/?utm_term=.a8a06216e91c [https://perma.cc/7A6LMTSS].
} 
Conservatives in the United States are generally supportive of, and deferential toward, big business interests. Conservative thinkers have indeed played a major role in weakening the antitrust laws and allowing consolidation and monopolization across the economy. ${ }^{105}$ In the name of "free markets," conservative politicians and commentators typically favor policies that support large corporations and place few restrictions on them. ${ }^{106}$

Nonetheless, more and more conservative voices are starting to raise concerns about corporate power. At present, many of the attacks reflect anger at certain companies, more than corporate power in general. Much of the conservative criticism appears driven by the perceived politics of their executives and employees more than a distrust of large corporations and their power in general. For example, Google is viewed as supportive of the Democratic Party and some liberal causes and it has drawn significant criticism from the right. ${ }^{107}$ Whatever the underlying motivation though, skepticism of large corporations, or at least a subset of them, is a growing strand of thought on the right.

At least on the surface, the Trump administration reflects this rising antimonopoly tendency among conservatives. President Trump has repeatedly attacked certain powerful corporations. ${ }^{108} \mathrm{He}$ has criticized the power of Amazon and its founder and chief executive officer, Jeff Bezos. ${ }^{109} \mathrm{He}$ has also condemned vertical integration in

105. See e.g., Robert H. Bork, The Antitrust Paradox (1978); Frank H. Easterbrook, Limits of Antitrust, 63 TEX. L. REV. 1 (1984).

106. Zach Carter, The GOP's Vision of Free Markets Looks a Lot Like Donald Trump's Real Estate Swindle, Huffington Post (Oct. 19, 2018, 6:24 PM), https:/www.huffingtonpost.com/entry/trump-paul-ryan-free-enterprisecronyism_us_5bca274be4b0d38b5877e8b1[https://perma.cc/WT9C-6R69].

107. E.g., John Hinderaker, It's Official: Google Is a Democratic Party Front, PowerLINE (Sept. 12, 2018), https://www.powerlineblog.com/archives/2018/09/its-official-google-is-ademocratic-party-front.php [https://perma.cc/A94Y-27Z6].

108. Danielle Wiener-Bronner \& Julia Horowitz, Amazon and 16 Other Companies Trump Has Attacked Since His Election, CNN (Apr. 4, 2018, 6:47 PM), https://money.cnn.com/2018/04/04/news/companies/trump-companies-attacks/index.html [https://perma.cc/E6GQ-A3LS].

109. Donald Trump (@RealDonaldTrump), TwitTER (Mar. 29, 2018, 4:57 AM), https://witter.com/realdonaldtrump/status/979326715272065024?lang=en

[https://perma.cc/4VFV-6W5M] ("I have stated my concerns with Amazon long before the Election. Unlike others, they pay little or no taxes to state \& local governments, use our Postal System as their Delivery Boy (causing tremendous loss to the U.S.), and are putting many thousands of retailers out of business!'); see also David Goldman, Trump's Latest Tweet Takes Down Amazon Stock and the Nasdaq, CNN (Apr. 3, 2018, 4:48 PM), https://money.cnn.com/2018/04/03/news/companies/amazon-stock/index.html

[https://perma.cc/5GCS-RM2X]; Donald Trump (@RealDonaldTrump), TwiTTER (July 23, 
telecommunications - specifically calling out the completed merger between Comcast and NBC Universal and the now-completed merger between AT\&T and Time Warner-for threatening to "destroy democracy." 110 His former chief strategist and right-wing icon, Steve Bannon, called for public utility regulation of tech platforms like Facebook and Google. ${ }^{111}$ Former Attorney General Jeff Sessions called for remedying the perceived liberal bias of these same tech platforms. ${ }^{112}$

Others on the right have sounded similar fears about corporate power. Senator Ted Cruz, who has been a major recipient of campaign contributions

2018, 6:35 AM), https://twitter.com/realDonaldTrump/status/1021388295618682881 [https://perma.cc/9C2J-V5UX] ("In my opinion the Washington Post is nothing more than an expensive (the paper loses a fortune) lobbyist for Amazon. Is it used as protection against antitrust claims which many feel should be brought?"); Trump Speaks in Pennsylvania; Examining Proposed Actions in First 100 Days of Trump Administration, CNN (Oct. 22, 2016, 12:00 PM), http://ranscripts.cnn.com/TRANSCRIPTS/1610/22/cnr.03.html [https://perma.cc/QK487RJM] ("They are trying desperately to suppress my vote and the voice of the American people as an example of the power structure I'm fighting, AT\&T is buying Time Warner and thus CNN. A deal we will not approve in my administration because it's too much concentration of power in the hands of too few. Likewise, Amazon, which through its ownership controls 'The Washington Post' ... . Additionally, Comcast purchase of NBC concentrates far too much power in one massive entity that is trying to tell the voters what to think and what to do. Deals like this destroy democracy. We'll look at breaking that deal up and other deals like that. This should never, ever have been approved in the first place.").

110. Emily Stephenson, Trump Vows To Weaken U.S. Media 'Power Structure' if Elected, REUTERS (Oct. 22, 2016, 10:25 AM), https://www.reuters.com/article/usa-election/trump-vowsto-weaken-u-s-media-power-structure-if-elected-idUSL1N1CS08H］[https://perma.cc/BXG2$4 \mathrm{~K} 7 \mathrm{X}$ ] ("And he added a new threat to his repeated criticisms of U.S. media companies, which he says cover his campaign unfairly to help Democratic candidate Hillary Clinton. 'They're trying desperately to suppress my vote and the voice of the American people,' he told supporters in his speech. 'As an example of the power structure I'm fighting, AT\&T is buying Time Warner and thus CNN, a deal we will not approve in my administration because it's too much concentration of power in the hands of too few,' Trump said. He also said he would look at 'breaking' up Comcast's acquisition of NBC Universal in 2013. 'Deals like this destroy democracy,' he said.').

111. Robinson Meyer, What Steve Bannon Wants To Do to Google, Atlantic (Aug. 1, 2017), https://www.theatlantic.com/technology/archive/2017/08/steve-bannon-googlefacebook/535473/ [https://perma.cc/3GQ2-7NAM] ("Bannon's endorsement of stronger antitrust enforcement (not to mention a higher top marginal tax rate) could very well be the advisor trying to signal that he is still different from Trump.").

112. Kim Hart, Why Jeff Sessions Scares Tech Companies, Axios (Feb. 17, 2017), https://www.axios.com/why-jeff-sessions-scares-tech-companies-1513300442-a1e15f14-74c54e6e-8419-c6042741a3f2.html [https://perma.cc/8263-KL2U] ("Sessions has gone after the tech industry for hiring high-skilled foreign workers and resisting law enforcement surveillance requests. Pile on Donald Trump's populist disdain for big companies and suspicion of some dominant tech platforms, and antitrust experts also say Silicon Valley has reason to be worried."). 
from large corporations, ${ }^{113}$ has endorsed using the antitrust laws against the power of tech platforms. ${ }^{114}$ Senator (and former Representative) Marsha Blackburn has criticized platforms like Google and YouTube for failing to practice viewpoint neutrality and called them out for apparent bias against individuals and organizations expressing conservative opinions. ${ }^{115}$

113. Greg Ferenstein, The Silicon Valley Libertarians Putting Serious Money Behind Ted Cruz, BreITBART (Mar. 25, 2015), https://www.breitbart.com/politics/2015/03/25/the-siliconvalley-libertarians-putting-serious-money-behind-ted-cruz/ [https://perma.cc/NRV7-CNM6] ("Paypal co-founder, Facebook investor, and self-styled libertarian Peter Thiel gave roughly $\$ 10,000$ to Ted Cruz's senate bid back in 2011 . However, it's his indirect contributions that really hit the mark. Thiel has shelled out an estimated \$2M to an arm of the libertarian political action group, Club for Growth.") ("Fully 58 percent $(\$ 10 \mathrm{M})$ of his individual contributions are from large check writers, and another $\$ 1.6 \mathrm{M}$ came from political action committees.") ("Sometimes propping up effective institutions means breaking the old ones down. Cruz, more than most politicians, represents a disruptive force. Disruption tends to be what Silicon Valley libertarians like. And, we should expect more of Ted Cruz-like contrarian politics as these technologists become more powerful.").

114. Robert Kraychik, Exclusive-Ted Cruz: Use Antitrust Laws To Break 'Massive Power' of Tech Lords To 'Subvert Our Democratic Process,' BREITBART (Apr. 25, 2018), https:/www.breitbart.com/radio/2018/04/25/exclusive-ted-cruz-use-antitrust-laws-to-breakmassive-power-of-tech-lords-to-subvert-our-democratic-process/ [https://perma.cc/7NVSD7XG] ("'I think, number one, the growing power of tech to censor speech is a profound threat. We're seeing now some two-thirds of Americans are getting their news through social media, and these tech companies are hard-left. They are partisan Democrats, and what we're seeing is they're amplifying the views they agree with, those of liberal Democrats, and they are suppressing the views of conservatives. They are blocking conservatives.") ("The scope of the power is truly unprecedented. You think back to the heights of yellow journalism, when publisher William Randolph Hearst controlled much of media and in fact got America into the Spanish-American War. These tech companies have power William Randolph Hearst could never have imagined. The ability, if there's a view they dislike, simply to silence it so that if you put a post out there, if you put a tweet out there, it simply goes into the void, into oblivion, and no one sees it. Likewise, they have the ability, if there are views they want to promote, to just have everything on your feed be the views they want to promote. That is invidious. It is invisible, and it is profoundly dangerous."') ("“A second remedy is considering using anti-trust laws. By any measure, Facebook is larger and more powerful than Standard Oil was the antitrust laws broke it up. It's larger and more power than AT\&T was when antitrust laws broke it up and given that, I think we need to have serious consideration about the massive power we're seeing of these tech companies to subvert our democratic process."').

115. Rep. Marsha Blackburn, Opinion, It's Time To Remind Silicon Valley that No One Is 'Too Big To Regulate,' Fox News (June 19, 2018), http:/www.foxnews.com/opinion/2018/06/19/rep-marsha-blackburn-its-time-to-remind-siliconvalley-that-no-one-is-too-big-to-regulate.html [https://perma.cc/8PH9-CKJ2] ("Many Tennesseans recalled the incident where I was subjected to censorship on Twitter. For the first time, they finally had an opportunity to speak up once there was an opportunity to hold a tech company accountable for their actions. Big Tech has gone from silencing us by blocking and censoring our content; to telling others what to think of us. We are left defenseless once they step into our shoes and speak for us ... . [M]y Tennessee constituents have expressed concern over 
Representative Jim Jordan (R-OH) expressed similar concerns and insinuated that stronger governmental measures should be applied to curb the power of giant social media companies. ${ }^{116}$ Senator Josh Hawley (R-MO) previously served as Missouri's attorney general and, during his tenure, opened an antitrust investigation into Google. ${ }^{117}$

Some conservative media outlets have in recent years been vocal critics of corporate power. Breitbart, the hard-right news outlet formerly run by Steve Bannon, has championed antitrust enforcement against large corporations. ${ }^{118}$

having their Christian movie trailers taken off YouTube, or their Facebook accounts being disabled, or their posts on Twitter being censored. As I said, I had a personal experience with the latter this last fall, and it was deeply troubling. I understand how these people felt. It started with confusion and ended with outrage. If these companies truly believe in a free and open internet, they should allow an honest and open public discussion - even when that means views they disagree with in 'flyover country' are highlighted .... What is the value of platforms that care more about inserting their biases than in providing a neutral place for people to discuss their ideas? This doesn't just apply to the words we choose to use to express ourselves, but also the way in which they classify us before the public. Recently, House Majority Leader Kevin McCarthy brought to our attention the fact that the California Republican Party was deemed a 'Nazi' organization on the front page of Google's search results . . . If Google is unfairly using their competitive advantage to stifle their competitors hopes of attracting new customers, it may be appropriate for regulators to take a closer look at this practice.").

116. Sean Moran, Exclusive-Jim Jordan: Social Media Giants 'Cannot Say They're an Open Platform and Restrict Free Speech, BreITBART (Aug. 3, 2018), https://www.breitbart.com/radio/2018/08/03/exclusive-jim-jordan-social-media-giants-cannotsay-theyre-an-open-platform-and-restrict-free-speech/ [https://perma.cc/8HCN-8XRV] ("They cannot say that they're an open platform and then restrict certain kinds of speech. If you are an open platform, you're an open platform, if not then you're a newspaper, and you're subject to different rules and regulations and different guidelines ... you have to pick which one you are .... If they are going to continue to do this, we are going to do a different approach to this sort of organization.").

117. Joshua Brustein, This Peter Thiel-Backed Senate Candidate Has It in for Google, Bloomberg (Mar. 8, 2018, 4:00 AM), https://www.bloomberg.com/news/articles/201803-08/josh-hawley-s-missouri-senate-bid-could-be-a-problem-for-google [https://perma.cc/7VBL-ECBF] ("In November [of 2017], Hawley subpoenaed Alphabet as part of an investigation into its possible violations of Missouri antitrust and consumer protection law.").

118. E.g., Fred Campbell, Campbell: Trump Should Break Up Google's Media Monopoly, BREITBART (June 21, 2017) https://www.breitbart.com/big-government/2017/06/21/campbelltrump-break-googles-media-monopoly/ [https://perma.cc/Q79U-N84Q]; Amanda House, Watch Live Breitbart News Town Hall- 'Masters of the Universe': Big Tech vs. Free Speech and Privacy, BREITBART (Apr. 5, 2018), https://www.breitbart.com/tech/2018/04/05/watch-livebreitbart-news-town-hall-masters-of-the-universe-big-tech-vs-free-speech-and-privacy/

[https://perma.cc/3MNR-98FD] ("'Big tech is the biggest threat to free speech at this moment in time, and there is no fiercer advocate for the first amendment than Breitbart News,' said Alex Marlow, editor-in-chief of Breitbart. 'Never has so much power been concentrated in the hands of so few people, and Silicon Valley elites have, thus far, been able to operate with virtually zero 
The American Conservative, a nativist right outlet that supports economic populism, has become a consistent critic of corporate power and supporter of renewed antitrust enforcement. ${ }^{119}$ Tucker Carlson, a commentator on Fox News, has endorsed public checks on Facebook and Google. ${ }^{120}$

transparency. The Masters of the Universe are unfathomably influential, secretive, and they are surveilling all of us right now, stockpiling our data for their own purposes. It's time we broaden the discussion.' . . . Topics of discussion will include anti-consumer practices by big Internet monopolies like Google and Facebook - and the effects of these practices on free speech, consumer privacy, and competition.").

119. See, e.g., Daniel Kishi, Against Bigness? Begin by Breaking Up Big Tech, Am. $\begin{array}{lllll}\text { Conservative (Nov. 28, 2018, } & \text { 12:01 }\end{array}$ https:/www.theamericanconservative.com/articles/against-bigness-begin-by-breaking-up-bigtech/ [https://perma.cc/TD47-RBLZ]; Daniel Kishi, Time for a Conservative Anti-Monopoly Movement, AM. Conservative (Sept. 19, 2017, 12:01 AM), https://www.theamericanconservative.com/articles/amazon-facebook-google-conservative-antimonopoly-movement/ [https://perma.cc/QK54-LK4S]; William A. Nitze, The Tech Giants Must Be Stopped, AM. Conservative (Apr. 16, 2018, 12:01 AM), https:/www.theamericanconservative.com/articles/the-tech-giants-must-be-stopped/ [https://perma.cc/6TKS-XXNS].

120. Konzerva, Tucker Carlson Tonight-Break Up Big Tech?, YouTuBE (Mar. 14, 2018), https:/www.youtube.com/watch?v=wL7UJMSApCw [7R8M-RBUT]; Free Press News, Tucker Carlson -Tech Tyranny —Disturbing Political Behavior by Video Monopoly, YouTuBE (Apr. 26, 2018), https://www.youtube.com/watch?v=22bnikzHrtQ [https://perma.cc/P8T2-XEVZ]; Fox News, Tucker: Google Must Be Regulated, YouTuBE (Aug. 14, 2017), https:/www.youtube.com/watch?v=VyGfOgxii8Q [https://perma.cc/35P5-S9F8] ("Google is the most powerful company in the history of the world. It is the portal through which the bulk of our information flows. That means if Google isn't on the level, neither is our understanding of the world. To an unprecedented extent, Google controls reality. Google has already shown a willingness to distort reality for ideological ends. Until they were sued for it in 2008, Google refused to allow anti-abortion advertisements on its platforms, even though they freely allowed pro-abortion ones. On the flip side, Google often blacklists certain sites from hosting ads which denies them revenue. Recently, Google-owned YouTube has instituted procedures to cut off revenue from so-called offensive content. What's offensive? Who decides? Well, it's an opaque process controlled by employees of the company ... no surprise, the offensive label is routinely applied to right-of-center content creators that they don't like. Google has also appointed itself the online sheriff of 'fake news' changing its search algorithm so that what it calls offensive or misleading news doesn't even show up in searches. You will never know it existed. It is now obvious that Google cannot be trusted to do any of this. Why should a company that shuts down free speech for political reasons have the power to dictate what the world knows and thinks? Well, of course, it shouldn't have that power. Google's long-time motto was 'don't be evil.' Now they use 'do the right thing.' We should have seen this coming. Those are super-villain slogans if there was ever such a thing. None of this can continue. In Europe, google has already been hit with a nearly $\$ 3$ billion fine for violating antitrust law, Congress here, and the Trump administration, should go further than that. Since it has the power to censor the internet, Google should be treated like the public utility that it is to make sure that it doesn't further distort the free flow of information to the rest of us. That needs to happen immediately. Too bad it has come to this. A lot of us trusted Google not to be evil. Silly us."). 
Conservative talk radio icon Rush Limbaugh described what he saw as a pernicious aspect to corporate ownership of media. ${ }^{121} \mathrm{He}$ stated that large, non-media corporations or their CEOs, for example Jeff Bezos purchasing The Washington Post, acquire media to shape policy and thereby increase their power. ${ }^{122}$ Even anti-government conspiracy theorist Alex Jones has called on the Trump administration to break up big technology companies because the supposedly left-leaning Silicon Valley titans are using their massive power to stifle conservative viewpoints. ${ }^{123}$

With rising awareness of, and opposition to, corporate power, an antimerger law that directly targeted corporate size could attract significant popular and political support. Senator Klobuchar's bill has already introduced size-based limits on consolidation into the political debate. ${ }^{124}$ Many liberals and progressives appear ready to embrace this idea. ${ }^{125}$ On the right, support for such a possibility is much less certain. ${ }^{126}$ Yet, a growing tide of criticism from conservative figures suggests at least one faction on the right may be open to preventing corporate growth through extremely large mergers and acquisitions. ${ }^{127}$

121. Rush Limbaugh, Don't Ignore the Bezos-Trump Feud, Rush LimBaugh SHOw (May 16, 2017), https:/www.rushlimbaugh.com/daily/2017/05/16/dont-ignore-the-bezos-trump-feud/ [https://perma.cc/6A6W-TLH].

122. Id. ("So here's Bezos owning the Washington Post, which gives him total control (if he wants to exercise it) of the editorial content of the paper. That's better than any lobbying firm he could have ever bought into or hired. And with the threat here that Trump might pursue him on antitrust, I think there's a whole dynamic here going on that may be a little bit beneath the surface.")(internal quotation marks omitted).

123. Andrew Blake, Infowars' Alex Jones Accuses Twitter of Manipulating Midterms by Banning His Account, WASH. TIMES (Sept. 7, 2018), https:/www.washingtontimes.com/news/2018/sep/7/alex-jones-accuses-twitter-ofmanipulating-midterm/ [https://perma.cc/AFP9-RH6F] ("'They are clearly ahead of the midterms trying to manipulate the election,' Mr. Jones said. 'This violates federal election laws, it violates [the Sherman Antitrust Act], it just violates everything that's near and dear to this country.'").

124. See Consolidation Prevention and Competition Promotion Act of 2017, S. 1812, 115th Cong. (2017).

125. See supra text accompanying notes 16-18; see also In Effort to Lower Costs for Consumers, Help Even Playing Field for Business, and Encourage Innovation-Klobuchar, Senators Introduce Legislation to Promote Competition, U.S. SENATOR Amy Klobuchar (Sept. 14, 2017), https:/www.klobuchar.senate.gov/public/index.cfm/news-releases?ID=FB9C644A2F7B-4FB1-9003-0E0C667E1027 [https://perma.cc/GMZ7-JQZH].

126. Jonathan Tepper, The Conservative Case for Antitrust, AM. Conservative (Jan. 28, 2019, 12:01 AM), theamericanconservative.com/articles/the-conservative-case-for-antitrustjonathan-tepper/ [https://perma.cc/Y6XF-ZX7P].

127. See, e.g., id. 


\section{The WeAK CASE FOR LARGe CORPORATE MERGERS 128}

While critics are likely to assert that our proposal would lead to the loss of merger-related efficiencies, this claim should be treated with extreme skepticism. Although the implicit premise of contemporary merger policy is that merger among firms is usually a desirable event, the evidence suggests that mergers among substantial firms on the whole do not result in positive outcomes over time, let alone significant efficiencies that can be proven in advance of the merger. Moreover, as Judge Posner recently noted, mergers that result in significant efficiencies are rare: "I wish someone would give me some examples of mergers that have improved efficiency. There must be some." ${ }^{129}$ Conglomerate mergers, in particular, are unlikely to generate efficiencies and, if anything, may generate inefficiencies as different and unrelated businesses are brought under a single firm's management. ${ }^{130}$ Thus, the potential social costs of a stricter policy against large conglomerate mergers are small.

\section{A. Empirical Work on Mergers Shows Few Efficiency Gains}

Overall the best evidence suggests that, on average, mergers are probably roughly neutral in terms of their overall effects on efficiency, costs, and productivity. ${ }^{131}$ Moreover, many of the efficiencies that are generated by

128. This section of this Article is adapted and condensed from material in contained in Carstensen \& Lande, supra note 4, at 822-36.

129. Scott Hemphill, Philadelphia National Bank at 50: An Interview with Judge Richard Posner, 80 ANTITRUST L.J. 205, 216 (2015).

130. See, e.g., Dennis C. Mueller, Mergers and Market Share, 67 REV. ECON. \& StATS. 259, 261-63 (1985).

131. The authors are grateful to Professors Dennis Carlton and Melissa Schilling for advice concerning this topic. None of the interpretations of these studies, however, should necessarily be attributed to Professors Carlton or Schilling.

Studies, some of which evaluate hundreds of mergers, showing overall mixed or essentially neutral overall results from mergers, depending upon a large number of variables, include: K.P. Ramaswamy \& James F. Waegelein, Firm Financial Performance Following Mergers, 20 REV. Quantitative Finance And Accounting 115 (2003); Raghavendra Rau \& Theo Vermaelen, Glamour, Value and the Post-Acquisition Performance of Acquiring Firms, 49 J. FIN. ECON. 223 (1998); Jarayr Haleblian \& Sydney Finkelstein, The Influence of Organizational Acquisition Experience on Acquisition Performance: A Behavioral Learning Perspective, 44 ADMIN. SCI. Q. 29 (1999); Laurence Capron, The Long-Term Performance of Horizontal Acquisitions, 20 Strategic Mgmt. J. 987 (1999); James D. Parrino \& Robert S Harris, Takeovers, Management Replacement, and Post-Acquisition Operating Performance: Some Evidence from the 1980s, 11 J. ApPlied CoRp. FIn. (2005); Michael L. McDonald, James D. Westphal \& Melissa E. Graebner, What Do They Know? The Effects of Outside Director Acquisition Experience on Firm 
mergers are likely to result from the more than ninety-nine percent of mergers that would be of no interest to enforcers if our proposal were enacted because they involve firms smaller than $\$ 10$ billion in assets. A modest number of studies show, on average, small efficiency gains from mergers. ${ }^{132} \mathrm{By}$

Acquisition Performance, 29 Strategic Mgmt. J. (2008). See also Bruce A. Blonigen \& Justin R. Pierce, Evidence for the Effects of Mergers on Market Power and Efficiency, NBER Working Paper No. 22750, issued in October 2016, available at http://www.nber.org/papers/w22750, at 1 [https://perma.cc/6FU8-XC6L] ("We use newly-developed techniques to separately estimate productivity and markups across a wide range of industries using detailed plant-level data. Employing a difference-in-differences framework, we find that M\&As are associated with increases in average markups, but find little evidence for effects on plant level productivity. We also examine whether M\&As increase efficiency through reallocation of production to more efficient plants or through reductions in administrative operations, but again find little evidence for these channels, on average. The results are robust to a range of approaches to address the endogeneity of firms' merger decisions."); Louis Kaplow \& Carl Shapiro, Antitrust, in 2 Handbook of LAw And Economics 1073, 1154 (A. Mitchell Polinsky \& Steven Shavell eds., 2007) (summarizing event study evidence showing that acquiring firms do not benefit from mergers on average).

132. For a recent survey see Dennis Carlton, Eugene Fama and Industrial Organization, THE FAMA PORTFOlio (John Cochrane, Tobias Moskowitz, ed.) (forthcoming). A slightly revised version appears as "How Eugene F. Fama has left his mark on industrial organization," in the Chicago Booth Review, (May 10, 2017). "Mergers don't seem to create market power but do seem to create efficiencies. There is an overall gain in value to the merged firm somewhere in the range of $0-10 \%$ (e.g., Andrade et al. [2001] report a 2\% gain) above the value of the separate firms' values, and that gain seems unrelated to market power . . . [so] any significant toughening of standards runs the risk of deterring efficiency-enhancing mergers." Id. at 2. A recent study showing overall positive effects from mergers is: Keith D. Brouthers, Paul van Hastenburg \& Joran van den Ven, If Most Mergers Fail Why Are They So Popular?, 31 Long Range Planning 347 (1998) ("These previous studies have consistently shown that acquiring firms do not benefit from mergers. . . . This study suggests that researchers have been using incorrect measures of merger performance, which accounts for their negative findings. The authors present a new methodology for measuring merger performance. . . . The results of applying this new methodology to a small sample of Dutch mergers indicate that mergers are extremely successful."); see also Steven N. Kaplan, Mergers and Acquisitions: A Financial Economics Perspective, Testimony before the Antitrust Modernization Commission, available at http://govinfo.library.unt.edu/AMC/commission_hearings/PDF/kaplan_statement.pdf

("Although the evidence is not uniform, on balance I would conclude that acquisitions create economic value. I rely on the announcement returns as the critical evidence. They have been reliably positive over the last 30 years, particularly for acquisitions that are cash financed. Acquisitions using stock are value neutral, but likely include a negative information component about the stand-alone firms. It is clear that shareholders of targets gain, while shareholders of acquirers experience mixed results. The accounting-based studies are more mixed, but are subject to more noise."). For an older survey see Dennis W. Carlton \& Jeffrey M. Perloff, Modern Industrial Organization (4th ed. 2004) ("In summary, stock market evidence supports the view that merger activity improves efficiency and improves value. . . Additional research on profits subsequent to consolidation, not on stock price, is needed to confirm these efficiency gains. Without such research, some may argue that mergers and takeovers create illusory stock market 
contrast, a very large and reputable body of findings show that, generally and overall, mergers lead to losses of productive efficiencies, ${ }^{133}$ including relatively large losses in some cases. ${ }^{134}$

value that represents either the unjustified transfer of wealth from those dependent on the acquired firm. . . . to its shareholders, or valuation errors by the stock market.") (also citing the above referenced 2001 Andrade \& Stafford study).

133. Studies showing overall results from mergers that are slightly negative include David R. King, Dan R. Dalton, Catherine M. Daily \& Jeffrey G. Covin, Meta-Analyses of Post-Acquisition Performance: Indications of Unidentified Moderators, 25 StRATEGIC MGMT. J. (2004) ("We find robust results indicating that, on average and across the most commonly studied variables, acquiring firms' performance does not positively change as a function of their acquisition activity, and is negatively affected to a modest extent."); Aloke Ghosh, Does Operating Performance Really Improve Following Corporate Acquisitions?, 7 J. CORP. FIN. 151 (2001) ("Previous research indicates that operating performance improves following corporate acquisitions relative to industry-median firms. Such performance results are likely to be biased because acquiring firms undertake acquisitions following a period of superior performance and they are generally larger than industry-median firms. Using firms matched on performance and size as a benchmark, I find no evidence that operating performance improves following acquisitions."); Vassilis M. Papadakis \& Ioannis C. Thanos, Measuring the Performance of Acquisitions: An Empirical Investigation Using Multiple Criteria, 21 BRITISH J. MgMT. 859 (2010) ("Overall, results from the three measures indicate failure rates from $50 \%$ to $60 \%$."); Patricia M. Danzon, Andrew Epstein \& Sean Nicholson, Mergers and Acquisitions in the Pharmaceutical and Biotech Industries, 28 MANAGERIAL \& DECISION ECON. (2007) ("Controlling for merger propensity, large firms that merged experienced a similar change in enterprise value, sales, employees, and $R \& D$, and had slower growth in operating profit, compared with similar firms that did not merge.").

134. Studies that show overall effects from mergers that are clearly negative on average include Paul Andre, Maher Kooli \& Jean-Francois L'Her, The Long-Run Performance of Mergers and Acquisitions: Evidence from the Canadian Stock Market, 33 Fin. MGMT. 27 (2004) (a study of 267 Canadian acquisitions shows that "acquirers significantly underperform over the threeyear post-event period."); Anup Agrawal, Jeffrey F. Jaffe \& Gershon N. Mandelker, The PostMerger Performance of Acquiring Firms: A Re-examination of an Anomaly, 47 J. Fin. 1605 (1992) ("[U]sing a nearly exhaustive sample of mergers between NYSE acquirers and NYSE/AMEX targets. We find that stockholders of acquiring firms suffer a statistically significant loss of about $10 \%$ over the five-year post-merger period, a result robust to various specifications."); Andrew P. Dickerson, Heather D. Gibson \& Euclid Tsakalotos, The Impact of Acquisitions on Company Performance: Evidence From a Large Panel of UK Firms, 49 OXFORD ECON. PAPERS 344 (1997) ("This paper investigates the impact of acquisitions on company performance using a large panel of UK-quoted companies observed over a long time period. The results indicate that acquisitions have a detrimental impact on company performance and that company growth through acquisition yields a lower rate of return than growth through internal investment."); David J. Ravenscraft \& F.M. Scherer, The Profitability of Mergers, 7 INT'L J. INDUS. ORG. 101 (1989) ("Following merger, the profitability of acquired entities declined except among pooling-of-interests merger partners of roughly equal pre-merger size."); Christian Tuch \& Noel O'Sullivan, The Impact of Acquisitions on Form Performance: A Review of the Evidence, 9 InT'L J. Mgmt. Revs. 141 (2007) (“("The evidence suggests that, in the short run, acquisitions have at best an insignificant impact on shareholder wealth. Long-run performance analysis reveals overwhelmingly negative returns, while the evidence using accounting performance measures is mixed."). 
Other empirical work is consistent with the rejection of any general expectation that major horizontal mergers are likely to result in increased productive efficiency. Professors Scherer and Ravenscraft found that most mergers have resulted in inefficiency. ${ }^{135}$ More recent studies, ${ }^{136}$ including studies of banking, insurance, and airlines, confirm this result. ${ }^{137}$ Professor Kwoka found that the numerous post-merger studies he reviewed (every respectable impact evaluation analysis he could find) reported little evidence of efficiency gains. ${ }^{138}$ Thus the earlier quoted conclusion by Judge Posner ("I wish someone would give me some examples of mergers that have improved efficiency. There must be some." ${ }^{139}$ ) should come as no surprise.

Conglomerate mergers are especially unlikely to generate productive efficiencies. History is very informative here. The conglomerate merger wave that happened in the 1960s and 1970s typically did not yield the promised managerial efficiencies. ${ }^{140}$ The conglomerate entrepreneurs often proved to be masters of financial wizardry, not competent managers. ${ }^{141}$ And by bringing disparate business lines under common management, conglomerate mergers demanded too much of even capable managers and produced poorly

135. F.M. Scherer \& David J. Ravenscraft, Mergers, Sell-offs, And Economic EFFICIENCY 202-03 (1987). Like most of these studies, this study looked at mergers generally and did not limit its focus to the large mergers of concern to antitrust.

136. See, e.g., Aloke Ghosh, Does Operating Performance Really Improve Following Corporate Acquisitions?, 7 J. CORP. FIN. 151, 151 (2001) (finding "no evidence that operating performance improves following acquisitions").

137. J. David Cummins, Sharon Tennyson \& Mary A. Weiss, Consolidation and Efficiency in the US Life Insurance Industry, 23 J. BANKING \& FIN. 325, 327 (1999) ("[L]arger [life insurance] firms generally are found to exhibit decreasing returns to sale."); Todd T. Milbourn, Arnoud W.A. Boot \& Anjan V. Thakor, Megamergers and Expanding Scope: Theories of Bank Size and Activity Diversity, 23 J. BANKING \& FIN. 195, 197-98 (1999) ("[Banking provides] little or no improvement in cost efficiency ... there is also a lack of empirical evidence that expansion of scope in banking has been beneficial."); Diana L. Moss, Delivering the Benefits? Efficiencies and Airline Mergers, AM. ANTITRUST INST. (2013), available at https://papers.ssrn.com/sol3/papers.cfm?abstract_id=2547673.

138. See KWOKA, supra note 8.

139. Hemphill, supra note 129.

140. Dennis C. Mueller, The Effects of Conglomerate Mergers: A Survey of the Empirical Evidence, 1 J. BANKING. \& FIN. 315, 344 (1977).

141. See Louis Hyman, Temp: How American Work, American Business, and the AMERICAN DREAM BECAME TEMPORARY 149-54 (2018) (tracing the rise and fall of James Ling and the conglomerate LTV). Conglomerate firms elevated the role of executives with a finance background. In contrast to CEOs with sales and marketing or production experience who brought expertise in a particular market or industry, finance-oriented CEOs could claim they had the ability to evaluate and compare unrelated businesses by looking at each line of business as an abstracted set of cash flows. Neil Fligstein, The ArChitecture of MARKets: An Economic Sociology of Twenty-First-Century CAPitAlist Societies 160 (2002). 
run, bloated organizations. ${ }^{142} \mathrm{~A}$ leading business publication concluded that these conglomerates "became far too diverse for any corporate leader to embrace. .. . [and] [1] ayer upon layer of management jobs were added to the structure." "143 These mergers had such poor results that many of them were undone in the 1980s. The leading conglomerates, such as ITT and Gulf \& Western, sold off many businesses, and companies like Texaco and Mobil returned to their core businesses and divested unrelated ones, including ESPN and Montgomery Ward, respectively. ${ }^{144}$ The then-dean of Northwestern University's Kellogg School of Management offered a grim assessment of the conglomerate phenomenon, "The thinking used to be that once a conglomerate was put together, the whole was more valuable than its parts . . . . Now the parts seem more valuable than the whole."145

Indeed, many of the gains to the merging parties likely to be proclaimed as "efficiency" benefits on closer analysis involve transferring costs to third parties. ${ }^{146}$ For example, when two large retailers combine and eliminate outlets, this imposes greater travel burdens on customers. The merged parties may have lower costs, but a broader economic calculus could show that the total social costs of the merger are overall neutral or even negative. ${ }^{147}$ Another false economy comes from exploiting enhanced buyer power to drive down the price of inputs. Such buyer power can offset an upstream oligopoly's seller power, but it is often used to lower prices to powerless suppliers. This is no more an efficiency than the gains to a monopolist from raising prices to purchasers. ${ }^{148}$

In sum, most studies have found that, on the whole, mergers do not on average increase net corporate efficiency. As Professor Schilling concluded, "Overall, the evidence for mergers having negligible or negative effects on value appears to outweigh the evidence for clearly positive or mixed effects

142. Fligstein, supra note 141 at 325-26.

143. Managers Who Are No Longer Entrepreneurs, Bus. WEEK, June 30, 1980, at 74, 81.

144. Walter Adams \& James W. Brock, The "New Learning" and the Euthanasia of Antitrust, 74 CALIF. L. REV. 1515, 1549-50 (1986) (internal quotation marks omitted). 1985).

145. Id. at 1550 (citing A Growing Disillusion with Conglomerates, N.Y. Times, Jan. 27,

146. This is ironic because a primary goal of the antitrust laws is to prevent wealth transfers from purchasers to firms with market power. See Lande, Wealth Transfers, supra note 28, at 151.

147. See Craig Lambert, Shadow Work: The Unpaid, Unseen Jobs that Fill Your Day (2015) (describing the many tasks that have devolved onto individuals which were once done for them).

148. See Peter C. Carstensen, Buyer Power and the Horizontal Merger Guidelines: Minor Progress on an Important Issue, 14 U. PA. J. BuS. L. 775 (2012). See generally Peter C. Carstensen, Competition Policy and the Control of Buyer Power: A Global Issue (2017). 
on value." ${ }^{149}$ In light of this empirical research, Congress can reasonably conclude that if it were to pass the legislation this Article advocates, it would not significantly impair the attainment of productive efficiencies and could indeed channel corporate strategy away from unproductive merger activity and toward beneficial investment in new products and facilities.

\section{B. Shareholders of the Resulting Firm Often Suffer Significant Losses}

A final basis for rejecting any general claims that mergers are generally desirable is that many empirical examinations of the results for shareholders show that on average the buyer and its investors suffer losses, not gains. In 1992, a major study, covering more than thirty years of mergers among publicly traded companies, reported that the surviving firm on average lost about ten percent of its value over a period of five years. ${ }^{150}$ Another group of researchers reported that the acquired businesses tended to suffer reduced profitability and loss of market position. ${ }^{151}$ In 2012 alone, publicly held companies wrote off $\$ 51$ billion dollars because of bad mergers. ${ }^{152}$

149. Melissa A. Schilling, Potential Sources of Value from Mergers and Their Indicators, 63 ANTITRUST BULL. 183, 190 (2018) ("A considerable body of research has attempted to assess whether, on average, mergers create or destroy shareholder value. Studies have used a wide range of methodological approaches (e.g., event studies, large panel analyses, case studies), samples (e.g., mergers in particular industries, mergers where both the acquirer and target are US publicly held firms, mergers that vary in the share that is taken by the acquirer), and performance measures (e.g., stock price reactions, long-run cumulative abnormal returns, accounting performance, productivity, patenting outcomes). It should be clear that there are large number of parameters that may vary in the construction of a research design to study the performance of mergers, and, not surprisingly, the research has fallen well short of a consensus.").

150. Agrawal, Jaffe \& Mandelker, supra note 134, at 1605-06.

151. Dennis C. Mueller \& Mark L. Sirower, The Causes of Mergers: Tests Based on the Gains To Acquiring Firms' Shareholders and the Size of Premia, 24 MANAGERIAL \& DECISION ECON. 373, 374 (2003) (citing five studies "that suggest that acquisitions significantly impair the long-term profitability or market shares of the acquired businesses"). That study also found that there was a strong tendency to overpay for acquisitions. Id. at 380, 388 ("“S]everal of our findings actually imply that mergers destroy more of the value of the bidding firms than is paid as premium to the target.").

152. Emily Chasan \& Maxwell Murphy, Companies Get More Wiggle Room on Soured Deals, WALL ST. J. (Nov. 11, 2013, 8:15 www.wsj.com/articles/SB10001424052702304868404579191940788875848 (reporting a study by Duff \& Phelps); see also Steven Lipin \& Nikhil Deogun, Big Mergers of the '90s Prove Disappointing to Shareholders, WALL ST. J. (Oct. 30, 2000, 2:40 AM), www.wsj.com/articles/SB972860303890013995 (reporting that Salomon Smith Barney's analysis of major mergers showed that the acquirers "on average underperformed" measured by both the S\&P 500 stock index and their peer group); Bhushan Bahree, Oil Mergers Leave Investors Gushing, but Do the Combinations Really Work?, WALL ST. J. (July 22, 1999, 1:46 
Other research is consistent with these findings. A comparison of successful buyers to the losing bidder in a corporate buyout found that the buyers had worse results over time than the unsuccessful bidders. ${ }^{153}$ In 2010 McKinsey reported: "Anyone who has researched merger success rates knows that roughly $70 \%$ of mergers fail." ${ }^{154}$ An article in the Harvard Business Review observed that "study after study puts the failure rate of mergers and acquisitions somewhere between 70\% and 90\%." 155 The basic point being that buyers have a tendency to overpay and not to realize the gains that they claimed to expect. Even the co-author of a leading article claiming acquisitions resulted in significant premiums for the buyer subsequently recanted and conceded that there were "significant negative returns . . . following a merger."156

Thus, measured by stock market results most large mergers are not in fact very helpful to the development of economic efficiency, innovation, or other consequences that are desirable from the perspective of the public interest. It follows that stronger anti-merger legislation does not create a significant risk of substantial loss of desirable economic outcomes.

Mergers' "disappointing results are ... consistent with the repeated observation that many motivations for merger are largely disconnected from achieving economic efficiency despite what the promoters may assert in

AM), www.wsj.com/articles/SB932592913980475039 ("Megamergers often flop, and oil mergers especially are prone to failure.").

153. Ulrike Malmendier, Enrico Moretti \& Florian S. Peters, Winning by Losing: Evidence on the Long-Run Effects of Mergers (Nat'1 Bureau of Econ. Research, Working Paper No. 18024, 2012), www.nber.org/papers/w18024.

154. McKinsey \& Co., Perspectives on Merger Integration 11 (2010) (copy on file with author).

155. Clayton M. Christensen, Richard Alton, Curtis Rising \& Andrew Waldeck, The Big Idea: The New M\&A Playbook, HARV. Bus. REV., Mar. 2011, at 3.

156. Richard S. Ruback, Comment, on Means of Payment in Takeovers: Results for the United Kingdom and the United States, in CORPORATE TAKEOVERS: CAUSES AND CONSEQUENCES 260, 262 (Alan J. Auerbach ed., 1988) (commenting on a study covering most American mergers from 1955 to 1985 where the shareholders in the successful buyer suffered an average seventeen percent decline in share value in the two years following the merger). Ruback was Michael C. Jensen's co-author in Michael C. Jensen \& Richard S. Ruback, The Market for Corporate Control: The Scientific Evidence, 11 J. FIN. ECON. 5 (1983), which is one of the most frequently cited statements of the thesis that changes in corporate control are efficiency enhancing and produce positive gains for both selling shareholders and shareholders in the buyer. 
securities filings and press briefings." ${ }^{157}$ A "publicly held corporation faces very substantial agency problems." 158

The shareholders are largely powerless when ownership is widely dispersed. The board of directors, the agent of the shareholders, is usually under the control of management, which in turn can shape both buying and selling decisions to serve its strategic interests. Moreover, third parties, takeover funds, legal and financial advisers, can and do reap benefits from promoting such transactions even when the result for the enterprise is negative. Hence, many major mergers arise from motivations unrelated to increased efficiency. ${ }^{159}$

For all these reasons the purchase and sale of large corporations does not consistently advance desirable economic results. These results should encourage Congress to seriously consider new anti-merger legislation.

\section{Our Proposal Would Not IMPAIR THE ATtAINMENT OF PRODUCTIVE EFFICIENCIES}

Even though large mergers do not produce significant efficiencies on average, our specific proposal would be especially unlikely to reduce corporate economic efficiency. Companies seeking to achieve economies of scale and other productive efficiencies could still proceed in one of two ways.

First, the merger could proceed so long as the acquiring company sold or spun off similarly sized assets. Since many or most of the mergers this proposal will affect will encompass a number of industries that are not horizontally or vertically related to one another, the acquiring company typically should be able to identify and spin off or sell assets in a way that would not diminish overall corporate efficiency. Thus, if the legislation contained $\$ 10$ billion thresholds, the acquiring company would be permitted

157. Peter C. Carstensen, The Philadelphia National Bank Presumption: Merger Analysis in an Unpredictable World, 80 ANTITRUST L.J. 219, 257 (2015). For one ironic evaluation, see Stanley Bing, Why We Love Mergers, ForTunE (Dec. 4, 2014), https://fortune.com/2014/12/04/why-we-love-mergers/ [https://perma.cc/HW7J-3BLK] (stating "a host of articles contend[s] that . . . up to $70 \%$ or $80 \%$ of . . . mergers dilute value rather than build it." But the interests of bankers, lawyers, journalists and Wall Street all drive the process so "[w]hen all the M\&As have been finished, we'll have five big companies that do everything"). See also Jonathan A. Knee, Bruce C. Greenwald \& Ava Seave, The Curse of the Mogul: What's Wrong With the World's LEAding MEdia CoMpanies (2011) (describing consistent over payment for media properties).

158. Carstensen, supra note 157, at 257. This is a longstanding issue in corporate governance. See, e.g., Adolf A. Berle \& Gardiner C. Means, The Modern Corporation and Private PROPERTY (1991).

159. Id. 
to keep a net of $\$ 9.9$ billion in assets from a merger - surely enough to attain almost any conceivable efficiency.

Second, companies would still have the freedom to achieve productive efficiencies through internal growth. Instead of buying their way to possible efficiencies, they would have an incentive to invest in new facilities and improve their own operations. Similarly, rather than enter new markets through acquisitions of existing firms, companies could always enter by setting up and investing in a new line of business. Indeed, strong merger policy can, in general, divert corporate management away from mergers and acquisitions and toward more socially valuable pursuits. The Clayton Act reflects this distinction between growth through merger and growth through internal expansion: it restricts the former and permits the latter. ${ }^{160}$ At present, under the agencies' tolerant approach to mergers, "managerial energies [are] devoted to sterile paper entrepreneurialism and the quick growth-throughmerger game" and "diverted from the critical task of investing in new plants, new products, and state-of-the-art manufacturing techniques."161

There is also a third possibility (albeit an option we believe to be unwise). Conglomerate merger legislation could include an explicit efficiencies defense. If Congress is determined to do this, we would strongly urge that any efficiencies defense be very narrow.

Today, the conflict between Supreme Court precedent on an efficiency defense and existing practice under the Clayton Act is rarely acknowledged. In a trio of decisions in the 1960 s, the Supreme Court explicitly rejected an efficiencies defense in merger challenges under the Clayton Act. ${ }^{162}$ Notwithstanding this controlling judicial precedent, the enforcement agencies have recognized an efficiencies defense in their Horizontal Merger

160. As the Supreme Court pointed out in United States v. Philadelphia National Bank, "one premise of an antimerger statute such as [Section 7 of the Clayton Act] is that corporate growth by internal expansion is socially preferable to growth by acquisition." 374 U.S. 321, 370 (1963); Peritz, supra note 26, at 198.

161. Walter Adams \& James W. Brock, The Proposed Emasculation of Section 7 of the Clayton Act, 65 NeB. L. ReV. 813, 819 (1986); see also Sandeep Vaheesan, American Prosperity Depends on Stopping Mega-Mergers, Fin. Times Alphaville (Apr. 25, 2019), https:/ftalphaville.ft.com/2019/04/25/1556192949000/American-prosperity-depends-onstopping-mega-mergers/ [https://perma.cc/7SVP-A6EU].

162. See Brown Shoe Co. v. United States, 370 U.S. 294, 344 (1962) (“Congress appreciated that occasional higher costs and prices might result from the maintenance of fragmented industries and markets. It resolved these competing considerations in favor of decentralization."); Phila. Nat'l Bank, 374 U.S. at 371 ("We are clear . . . that a merger the effect of which 'may be substantially to lessen competition' is not saved because, on some ultimate reckoning of social or economic debits and credits, it may be deemed beneficial."); FTC v. Procter \& Gamble Co., 386 U.S. 568, 580 (1967) ("Possible economies cannot be used as a defense to illegality."). 
Guidelines since 1982 and inspired its acceptance in the lower courts. ${ }^{163}$ Today, in part informed by the agency's merger guidelines, most, but not all, lower courts have tentatively recognized an efficiencies defense. ${ }^{164}$ As the next section of this Article will demonstrate, mergers should not have an efficiencies defense.

If Congress believes an efficiencies defense is appropriate, we recommend giving the merging parties a very limited, consumer-oriented defense. We propose that Congress require that the merging parties be required to show, by "clear and convincing evidence," efficiencies that will be "passed on to consumers" and that "[cannot] be achieved through" non-merger means such as "internal expansion" or contractual arrangements." 165 The proposed defense would require detailed factual documentation and would not be satisfied through theoretical assertions.

Nevertheless, as the next section will demonstrate, even a narrow efficiencies defense would vastly increase the complexity of the law while undermining its predictability and dramatically increasing the risk of subjective enforcement and judicial decision-making.

\section{RULE OF LAW AND OTHER JURISPRUDENTIAL ISSUES}

Our proposed anti-conglomerate merger law would improve the objectivity and transparency of anti-merger enforcement. Current antimerger enforcement is tied to the open-ended, rule of reason style framework articulated in the Horizontal Merger Guidelines. ${ }^{166}$ The prevailing method of (2010)

163. Dep't of Justice \& Fed. Trade Comm’n, Horizontal Merger Guidelines $\S 10$

164. Some courts have assumed an efficiencies defense while expressing deep skepticism about its legality and emphasizing the vitality of the Supreme Court's merger decisions from the 1960s. FTC v. Penn State Hershey Med. Ctr., 838 F.3d 327, 347 (3d Cir. 2016) ("We note at the outset that we have never formally adopted the efficiencies defense. Neither has the Supreme Court."); Saint Alphonsus Med. Ctr.-Nampa, Inc. v. St. Luke's Health Sys., Ltd., 778 F.3d 775, 790 (9th Cir. 2015) ("We remain skeptical about the efficiencies defense in general and about its scope in particular. It is difficult enough in $\S 7$ cases to predict whether a merger will have future anticompetitive effects without also adding to the judicial balance a prediction of future efficiencies.”). But see ProMedica Health Sys., Inc. v. FTC, 749 F.3d 559, 571 (6th Cir. 2014) (formally recognizing an efficiencies defense); FTC v. Tenet Health Care Corp., 186 F.3d 1045 (8th Cir. 1999); FTC v. Univ. Health, Inc., 938 F.2d 1206 (11th Cir. 1991);

165. William J. Kolasky \& Andrew R. Dick, The Merger Guidelines and the Integration of Efficiencies into Antitrust Review of Horizontal Mergers, U.S. DePARTMENT OF JusticE ArChives, 1, 16, 31, n.91. See Phila. Nat'l Bank, 374 U.S. at 363 ("[Mergers] must be enjoined in the absence of evidence clearly showing that the merger is not likely to have such anticompetitive effects.") (emphasis added).

166. DeP’'T OF Justice \& Fed. TRAde COMM’N, supra note 163, at $\S \S 4-10$. 
merger analysis prioritizes identifying potential anticompetitive effects and discounts market share and concentration numbers. ${ }^{167}$ This framework promotes subjective enforcement and judicial decision-making in merger cases. Furthermore, current merger reviews are nonpublic, opaque, and rarely subject to after-the-fact testing of agency decisions, prompting one notable antitrust lawyer to quip that merger reviews are the least transparent governmental process outside of intelligence gathering. ${ }^{168}$

By contrast, our suggested legislation would incorporate social and political considerations into merger enforcement and also be clear and predictable and minimize subjectivity. The statute would contain express dollar limits (i.e., corporations may not merge if their assets each exceed $\$ 10$ billion). This decision rule would be as clear and objective as any antitrust rule can be. Especially because one of the companies would usually be making an offer for the stock of the other, the enforcers and the courts almost always would find it relatively easy to determine whether both companies were above the designated thresholds. While some ambiguity may exist on the margins of the threshold level, this ambiguity would be far less than the ambiguity that exists for mergers evaluated under the current interpretation of the Clayton Act. ${ }^{169}$

Of course, the merging parties could try circumventing the law's specified limits by, for example, dividing a $\$ 50$ billion company into six parts and merging each of the parts into the acquiring company seriatim. To prevent this from happening, the law should contain a provision that would consider as an aggregation all the assets that had been the property of either of the merging firms. The law could, for example, provide that the law's assets threshold applied to anything owned by the acquired company within ten years of the date of the acquisition. ${ }^{170}$ Under this approach a large company would be unable to acquire another by purchasing it in parts within a ten-year period. ${ }^{171}$

167. Id. For a comprehensive critique of the antitrust rule of reason see generally Maurice E. Stucke, Does the Rule of Reason Violate the Rule of Law?, 42 U.C. DAVIS L. REV. 1375 (2008). Judge Taft famously wrote that analyzing the "reasonableness" of restraints of trade requires "set[ting] sail on a sea of doubt." United States v. Addyston Pipe \& Steel Co., 85 F. 271, 283-84 (6th Cir. 1898).

168. Eisinger \& Elliott, supra note 71.

169. See United States v. AT\&T, Inc., 916 F.3d 1029 (D.C. Cir. 2019), and the 2010 AT\&T merger which involved $\$ 1$ billion in transaction costs.

170. The period should start many years before each merger in question, and extend for years afterwards, to prevent the parties from attempting to circumvent it.

171. A stricter alternative would be to prevent any company with assets exceeding $\$ 10$ billion to acquire more than $\$ 10$ billion of assets from all mergers or acquisitions combined within a lengthy period of time, such as ten years. 
Our proposal promotes ease of administration and predictability because it would mandate a simple hard asset cap on all mergers. Its two sources of complexity are the elements that permit mergers and acquisitions under certain conditions: its "cap and spinoff option" and, especially, any efficiencies defense.

The "cap-and spinoff" feature would give rise to administrative and transaction costs. First, the antitrust agencies would have to review proposed spinoffs under the Clayton Act to ensure that they do not threaten to diminish competition in other markets. Spinoffs carry the risk of enhancing the market power of the firm or firms that purchase the divested assets in one or more markets. Second, management would have to identify assets equal to or larger than those of the acquired company-plus just under $\$ 10$ billion. In other words, it would have to identify and sell assets so large that the transaction would no longer violate the new law. ${ }^{172}$ For example, suppose the law prevented two companies with $\$ 10$ billion or more in assets from merging, and suppose that two $\$ 50$ billion companies wanted to merge. The acquiring company would have to identify and then sell or spin off at least $\$ 40.1$ billion of its overall tentative post-merger $\$ 100$ billion in assets to satisfy the asset cap. In this way the acquiring company would be increasing its size only by $\$ 9.9$ billion, and so would not violate the law.

This would mean that if the legislation used relatively large (we believe unwisely large) $\$ 50$ billion thresholds, a $\$ 100$ billion company could legally increase its size by $\$ 49.9$ billion. Accordingly, Congress should instead choose a relatively low threshold, such as $\$ 10$ billion. This would mean that a $\$ 100$ billion company could purchase another $\$ 100$ billion company and, if it spun off enough assets, ultimately increase its size by $\$ 9.9$ billion. Although by many standards this still would be an enormous merger, it would be below the explicit $\$ 10$ billion threshold established by the law.

Simplicity also cuts dramatically against the inclusion of an efficiencies defense. If Congress does include an efficiencies defense, this would significantly reduce predictability and increase mergers transaction costs, and vastly increase the discretion given to enforcers and judges. ${ }^{173}$ Some of the largest mergers that have been evaluated under the current enforcement approach have involved transaction costs approaching $\$ 1$ billion ${ }^{174}$ and

172. The law could include a provision requiring the enforcers to only approve the spin offs or sales during their merger negotiations with the parties if the enforcers believed that the assets would constitute viable ongoing businesses.

173. See, e.g., Alan A. Fisher \& Robert H. Lande, Efficiency Considerations in Merger Enforcement, 71 CALIF. L. REV. 1580, 1654-59 (1983).

174. See United States v. AT\&T, Inc., 916 F.3d 1029 (D.C. Cir. 2019), and the 2010 AT\&T merger which involved $\$ 1$ billion in transaction costs. 
significant delays. One of the advantages of our proposal, that it would be relatively simpler to implement, would be reduced significantly by an efficiencies defense. This is particularly true because the evidence strongly supports a general skepticism toward claims of efficiencies from large corporate mergers, and it is extremely difficult for the enforcers and courts to predict in advance which mergers will result in significant efficiencies. ${ }^{175}$ This task is especially difficult because the vast majority of mergersperhaps up to ninety percent - result in no significant net efficiencies, or in losses (as was discussed supra). "[T]hose few merges that result in [significant] efficiencies are almost impossible to identify reliably in advance." $" 176$

For this reason, an efficiencies defense would seriously undermine one of the biggest advantages of our proposal - that it would increase predictability, certainty, and the rule of law compared to the current way mergers are analyzed. Moreover, currently efficiencies from mergers must not only be predicted as to their existence and significance. ${ }^{177}$ They must also "be balanced against any anticompetitive effects" that the merger produces. ${ }^{178}$ Agencies and courts undertake a "cost-benefit analysis" that is more characteristic of legislative and regulatory policy-making than case-by-case adjudication. ${ }^{179}$

175. Id.; see also Alan A. Fisher, Frederick I. Johnson \& Robert H. Lande, Price Effects of Horizontal Mergers, 77 CAL. L. REV. 777 (1989).

176. Carstensen \& Lande, supra note 4, at 818.

177. Federal Antitrust Policy in the Health Care Marketplace: Hearing Before the Comm. on the Judiciary, 105th Cong. 40 (1997) (statement of William G. Kopit).

178. Id.

179. Craig W. Conrath \& Nicholas A. Widnell, Efficiency Claims in Merger Analysis: Hostility or Humility, 7 GEO. MASON L. REV. 685, 702 (1999). Justice Thurgood Marshall explained this important point in a decision for the Supreme Court, explaining why the courts should not be weighing the harms and benefits of a challenged trade restraint. He wrote:

There have been tremendous departures from the notion of a free-enterprise system as it was originally conceived in this country. These departures have been the product of congressional action and the will of the people. If a decision is to be made to sacrifice competition in one portion of the economy for greater competition in another portion, this too is a decision that must be made by Congress and not by private forces or by the courts. Private forces are too keenly aware of their own interests in making such decisions and courts are ill-equipped and ill-situated for such decisionmaking. To analyze, interpret, and evaluate the myriad of competing interests and the endless data that would surely be brought to bear on such decisions, and to make the delicate judgment on the relative values to society of competitive areas of the economy, the judgment of the elected representatives of the people is required.

United States v. Topco Assocs., Inc., 405 U.S. 596, 611-12 (1972). 
Although we believe it would be unwise, the proposed narrow efficiency defense would be the least harmful way to incorporate efficiencies. Our proffered legislation would treat significant efficiencies as an absolute defense - so long as the merging parties could demonstrate "by clear and convincing evidence" that the merger will produce significant mergerspecific efficiencies that will be passed to consumers and that these efficiencies cannot be achieved through non-merger alternatives such as internal expansion or contractual arrangements. Thus, the efficiencies would not have to be weighed against any anticompetitive effects of the merger.

\section{CONClusion: Preventing The CURSE OF BIGNESS ${ }^{180}$}

We are proposing that Congress enact legislation that would block the very largest corporate mergers - every merger in which both corporations have more than $\$ 10$ billion in assets-regardless whether they are horizontal, vertical, or conglomerate. The legislation this article has outlined should significantly reduce increases in the concentration of political and other forms of non-economic power caused by corporate mergers. The legislation would recover and build upon antitrust law's historic embrace of public concerns with the economic and political power of the very largest corporations. But this time these concerns would be directly incorporated into the text and substance of the antitrust laws.

This legislation would accomplish its goals in a manner that is simple and administrable. It would not cause any significant decreases in economic efficiency. Nor would it cause any "rule of law" problems. In fact, it would be clearer, faster, more predictable, less expensive, and less subjective and discretionary than the evaluations of mergers under the current approach.

Our proposal would only affect approximately one percent of the thousands of corporate mergers large enough to be reportable to the federal antitrust enforcers each year. ${ }^{181}$ Yet, it would restrict an important driver of

180. In this Article's and this section's title we pay homage to Justice Brandeis, who believed: " $[\mathrm{N}] \mathrm{o}$ monopoly in private industry in America has yet been attained by efficiency alone. . . It will be found that wherever competition has been suppressed it has been due either to resort to ruthless processes, or by improper use of inordinate wealth and power. The attempt to dismember existing illegal trusts is not, therefore, an attempt to interfere in any way with the natural law of business. It is an endeavor to restore health by removing a cancer from the body industrial." BRANDEIS, supra note 44, at 114-16.

181. See Dep't of Justice \& Fed. Trade Comm'n, Hart-Scott-Rodino Annual Report, FISCAL YEAR 20171 (2018), https://www.ftc.gov/system/files/documents/reports/federal-tradecommission-bureau-competition-department-justice-antitrust-division-hart-scott- 
corporate gigantism. Mega-mergers, which are proposed on seemingly a weekly basis at present, would be off the table. Very large corporations would no longer have the option of merging, with little or no antitrust concern, and augmenting their existing economic and political power. Our proposal would certainly not cure the curse of bigness. It would, however, strike an important blow against it getting worse.

rodino/p110014_fy_2017_hsr_report_final_april_2018.pdf [https://perma.cc/72KT-EKCS] (“In fiscal year 2017, 2,052 transactions were reported under the HSR Act, representing about a 12.0 percent increase from the 1,832 transactions reported in fiscal year 2016.”). 


\section{ApPendix I: Proposed Model CONGLOMERAte Merger LEGislation}

Proposed Section 7B of the Clayton Act

1. Notwithstanding any other provision of law, no person shall merge, combine or consolidate with any other person engaged in or affecting the commerce of the United States, or acquire, directly or indirectly, any of the voting securities or assets of such other person, or acquire, directly or indirectly, any of the assets of such other person, if each person has assets exceeding $\$ 10,000,000,000$. This figure should be adjusted yearly to account for inflation.

2(a). It shall be an affirmative defense to an offense under Section 1 if the merging parties, within one year before or after the consummation of the transaction, shall have divested one or more viable business units, the assets of which are equal to or greater than the assets and revenues of the smaller party to the transaction; and

2(b). The assets threshold in Section 1 of this law apply to any assets owned by any acquiring or acquired company at any time from 10 (ten) years before the announced date of the merger, to 10 (ten) years after the announced date of the merger. These assets shall be aggregated and compared to the thresholds in Section 1, and if these assets exceed these thresholds, the merger may not proceed.

3. Nothing contained in this Section shall be construed to provide a defense or immunity to any acquisition that would otherwise violate any of the other federal or state antitrust laws. Nothing in this Act shall be deemed to authorize or make lawful anything heretofore prohibited or made illegal by other antitrust laws.

4. This law shall apply to all transactions announced or commenced after January 1, 2020. All of the amounts contained in Section 7(B) shall be adjusted for inflation by the FTC, which will use the Consumer Price Index for this purpose and will annually publish the revised asset thresholds to which this law applies.

5. Authority to enforce compliance with this section is vested in the Attorney General of the United States and the Federal Trade Commission.

Note: this proposed legislation modifies and updates S. 600, a Bill introduced by Senator Kennedy in 1979. For the language of Senator Kennedy's Bill see Joseph F. Brodley, Limiting Conglomerate Mergers: The Need for Legislation, 40 OHIO ST. L.J. 867, 893-94 (1979). 


\section{APPENDIX II}

\section{Nicholas Jordan*}

Number of Mergers \& Acquisitions Where Both Firms' Assets Exceeded Specified Amounts

\begin{tabular}{lcccccc}
\cline { 2 - 6 } $\mathbf{2 0 1 9}$ & $\mathbf{\$ 1 0 B}+$ & $\mathbf{\$ 2 5 B}+$ & $\mathbf{\$ 5 0 B}+$ & $\mathbf{\$ 7 5 B}+$ & $\mathbf{\$ 1 0 0 B}+$ & Total \\
\cline { 2 - 7 } $\mathbf{2 0 1 8}$ & 24 & 13 & 7 & 1 & - & 24 \\
$\mathbf{2 0 1 7}$ & 16 & 6 & 1 & - & - & 16 \\
$\mathbf{2 0 1 6}$ & 14 & 6 & 3 & 1 & 1 & 14 \\
$\mathbf{2 0 1 5}$ & 24 & 7 & 4 & 3 & 1 & 14 \\
Total & 92 & 46 & 23 & 8 & 4 & 92
\end{tabular}

\section{A CAVEAT CONCERNING THIS MATERIAL IN THIS APPENDIX}

Many of the values, dispositions, and classifications in this Appendix are subject to a number of potentially important qualifications and judgement calls. The material is of course based upon a variety of sources. Although every attempt was made to use only reliable sources, some of these sources may be more reliable than others. Further, some disparities exist between sources as to the true value of some of the transactions. For example, some sources report acquired debt and some do not, some sources report final transaction price while others only report the initial offer price, etc. Additionally, many sources do not disclose or fully disclose under what conditions the merger or acquisition was permitted. We expect there to be at

\footnotetext{
${ }^{*}$ J.D. expected May 2020, University of Baltimore, School of Law.
} 
least a few instances where a merger we marked as "permitted in full" was actually limited in some way, yet these limitations were not mentioned in the sources we found. Some of these limitations may have been trivial and not worth considering. But others might actually have been significant, even though to a reporter or a researcher reading news accounts they seem unimportant. Indeed, even defining a transaction as a "merger or acquisition" instead of a joint venture or acquisition followed by a spin-off can be a judgement call. See, for example, the Dell/Vmware transaction, described in Samuel Stebbins, The 10 Biggest Mergers and Acquisitions of 2018, USA TODAY (Dec. 10, 2018), https://www.usatoday.com/story/ money/business/2018/12/10/mergers-and-acquisitions-2018-10-biggestcorporate-consolidations/38666639/_[https://perma.cc/RGB8-96VB]; Energy Transfer Equity, FORTUNE (Mar. 29, 2018), http://fortune.com/fortune500/energy-transfer-equity/

[https://web.archive.org/web/20191121075450/https://fortune.com/fortune5 00/2019/energy-transfer/]. See also Andrew Bary, Dell's Public Debut Produces Fresh Winners and Losers, BARRON's (Dec. 28, 2018), https://www.barrons.com/articles/dell-buys-out-vmware-tracker-goespublic-51546020573.

Lastly, these tables include events that occurred between January 1, 2015 and December 31, 2019. 
StATUS OF EACH ATTEMPTED MERGER OR ACQUiSITION: SUMMARY

\begin{tabular}{|c|c|c|c|c|c|c|}
\hline & 2019 & 2018 & 2017 & 2016 & 2015 & Total \\
\hline $\begin{array}{l}\text { Blocked by a U.S. } \\
\text { court on antitrust } \\
\text { grounds }\end{array}$ & - & - & - & - & 2 & 2 \\
\hline $\begin{array}{l}\text { Abandoned after } \\
\text { U.S. antitrust } \\
\text { challenge } \\
\text { threatened or } \\
\text { announced }\end{array}$ & - & - & - & 1 & - & 1 \\
\hline $\begin{array}{l}\text { Blocked on non- } \\
\text { antitrust Grounds }\end{array}$ & - & - & 1 & 1 & - & 2 \\
\hline $\begin{array}{l}\text { Abandoned on } \\
\text { non-antitrust } \\
\text { grounds }\end{array}$ & 2 & - & - & - & 1 & 3 \\
\hline $\begin{array}{l}\text { Approved subject } \\
\text { to a conduct- } \\
\text { oriented consent } \\
\text { decree under U.S. } \\
\text { antitrust law }\end{array}$ & - & - & - & 1 & 1 & 2 \\
\hline $\begin{array}{l}\text { Approved subject } \\
\text { to spin offs and } \\
\text { divestitures under } \\
\text { U.S. antitrust law }\end{array}$ & 5 & 3 & 7 & 8 & 6 & 29 \\
\hline $\begin{array}{l}\text { Unchallenged and } \\
\text { permitted in full }\end{array}$ & 9 & 11 & 6 & 2 & 14 & 42 \\
\hline $\begin{array}{l}\text { Challenged under } \\
\text { U.S. antitrust law } \\
\text { but eventually } \\
\text { permitted in full }\end{array}$ & 1 & - & - & 1 & - & 2 \\
\hline Pending & 7 & 2 & - & - & - & 9 \\
\hline Total & 24 & 16 & 14 & 14 & 24 & 92 \\
\hline
\end{tabular}


MERgers \& ACQUisitions Where Both FiRms’ Assets ExCEEDED \$10

\author{
BILLION
}

\begin{tabular}{|c|c|c|c|}
\hline & Merger & Value & Disposition \\
\hline \multirow[t]{13}{*}{2019} & $\begin{array}{l}\text { Philip Morris Int' } 1 / \\
\text { Altria Group }^{\mathrm{i}}\end{array}$ & $\$ 95 \mathrm{~B}$ & $\begin{array}{l}\text { Abandoned on non-antitrust } \\
\text { grounds }\end{array}$ \\
\hline & $\begin{array}{l}\text { Bristol-Myers } \\
\text { Squibb/Celgene }\end{array}$ & $\$ 74 B$ & $\begin{array}{l}\text { Approved subject to spin offs and } \\
\text { divestitures under U.S. antitrust } \\
\text { law }\end{array}$ \\
\hline & $\begin{array}{l}\text { Saudi Aramco/ } \\
\text { Saudi Basic } \\
\text { Industries }^{v}\end{array}$ & $\$ 69.1 \mathrm{~B}$ & Pending $^{\mathrm{vi}}$ \\
\hline & AbbVie/Allergan ${ }^{\mathrm{vii}}$ & $\$ 63 \mathrm{~B}$ & Pending viii \\
\hline & $\begin{array}{l}\text { Occidental } \\
\text { Petroleum/ } \\
\text { Anadarko }^{\text {ix }}\end{array}$ & $\$ 57 \mathrm{~B}$ & Unchallenged and permitted in full ${ }^{\mathrm{x}}$ \\
\hline & $\begin{array}{l}\text { United } \\
\text { Technologies/ } \\
\text { Raytheon }^{\mathrm{xi}}\end{array}$ & $\$ 55 \mathrm{~B}$ & $\begin{array}{l}\text { Approved subject to spin offs and } \\
\text { divestitures under U.S. antitrust } \\
\text { law }^{\text {xii }}\end{array}$ \\
\hline & $\begin{array}{l}\text { Fiat Chrysler/ } \\
\text { Groupe PSA }\end{array}$ & $\$ 50 \mathrm{~B}$ & Pending ${ }^{\text {xiv }}$ \\
\hline & $\begin{array}{l}\text { Chevron/ } \\
\text { Anadarko }^{\mathrm{xv}}\end{array}$ & $\$ 47.5 \mathrm{~B}$ & $\begin{array}{l}\text { Abandoned on non-antitrust } \\
\text { grounds } \mathrm{s}^{\mathrm{xvi}}\end{array}$ \\
\hline & $\begin{array}{l}\text { Fiserv/ } \\
\text { First Data }^{x v i i}\end{array}$ & $\$ 38.2 \mathrm{~B}$ & $\begin{array}{l}\text { Unchallenged and permitted in } \\
\text { full }^{\text {xviii }}\end{array}$ \\
\hline & $\begin{array}{l}\text { Fidelity National } \\
\text { Information } \\
\text { Services/ } \\
\text { Worldpay }\end{array}$ & $\$ 35 \mathrm{~B}$ & $\begin{array}{l}\text { Unchallenged and permitted in } \\
\text { full }^{\mathrm{xx}}\end{array}$ \\
\hline & BB\&T/SunTrust ${ }^{\mathrm{xxi}}$ & $\$ 29.7 \mathrm{~B}$ & $\begin{array}{l}\text { Approved subject to spin offs and } \\
\text { divestitures under U.S. antitrust } \\
\text { law }^{\text {xxii }}\end{array}$ \\
\hline & $\begin{array}{l}\text { London Stock } \\
\text { Exchange/ } \\
\text { Refinitiv }^{\text {xxiii }}\end{array}$ & $\$ 27 \mathrm{~B}$ & Pending ${ }^{\text {xiv }}$ \\
\hline & $\begin{array}{l}\text { Charles } \\
\text { Schwab/TD } \\
\text { Ameritrade }^{\mathrm{xxv}}\end{array}$ & $\$ 26 \mathrm{~B}$ & Pending ${ }^{\mathrm{xxvi}}$ \\
\hline
\end{tabular}




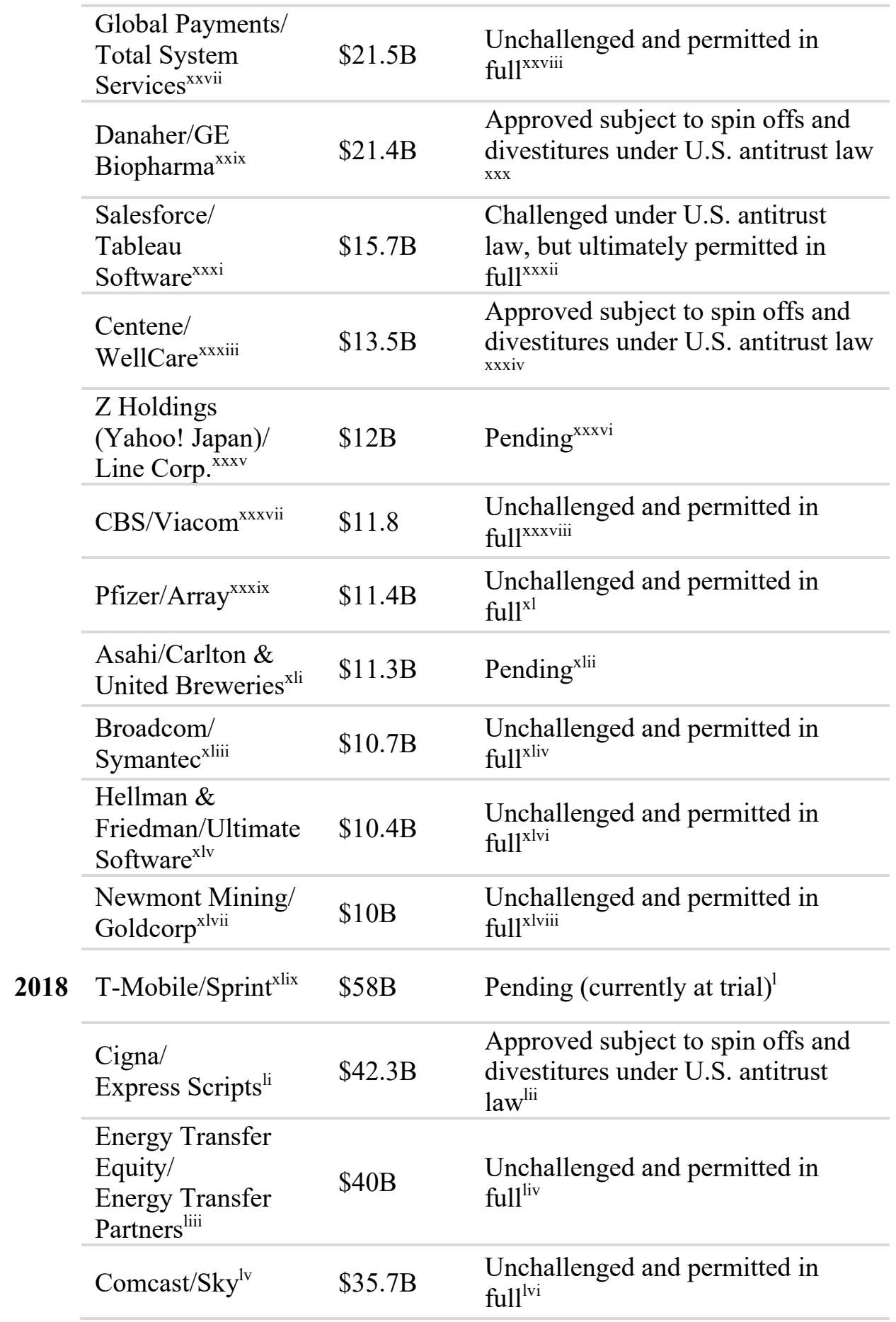




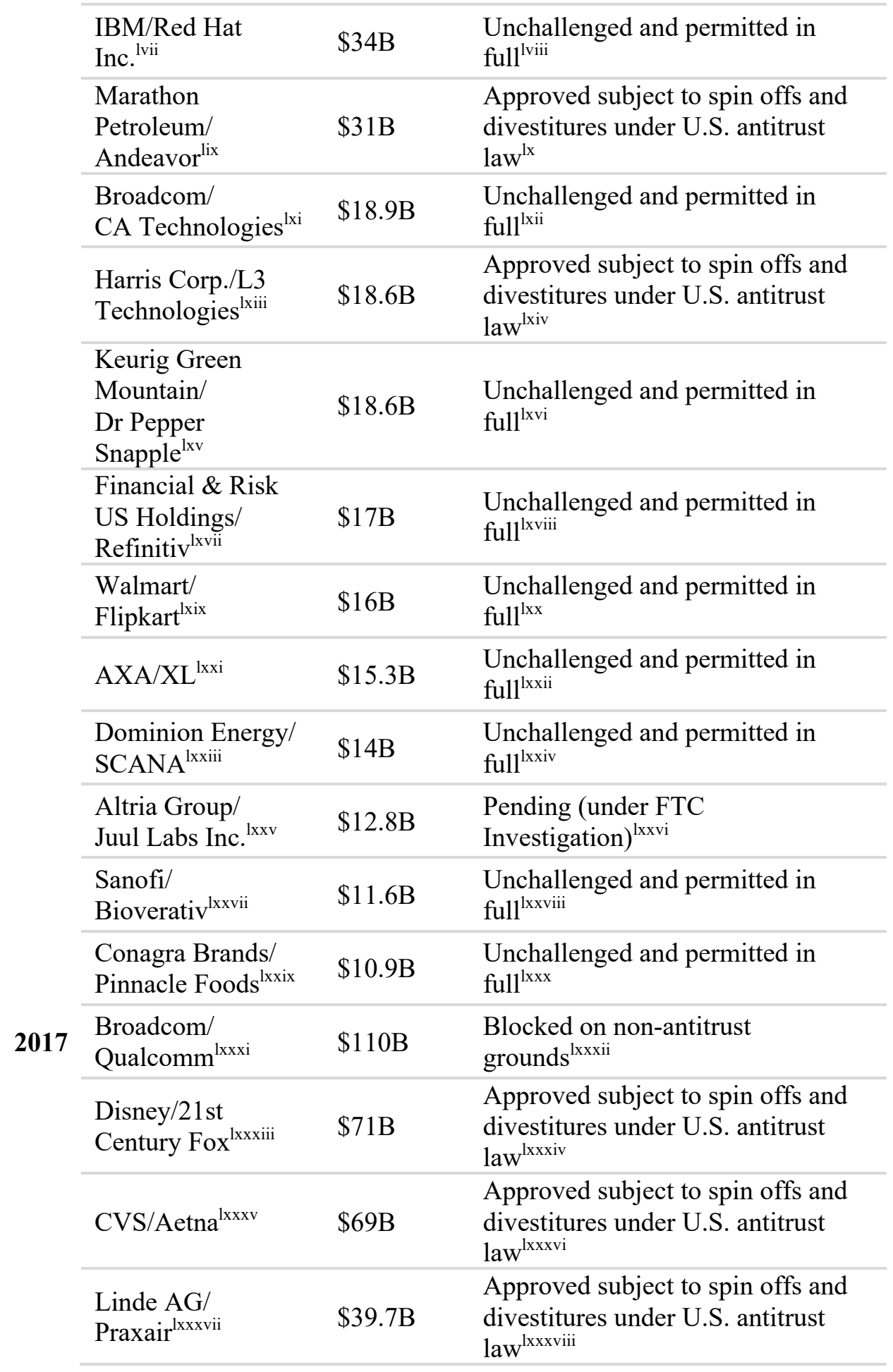




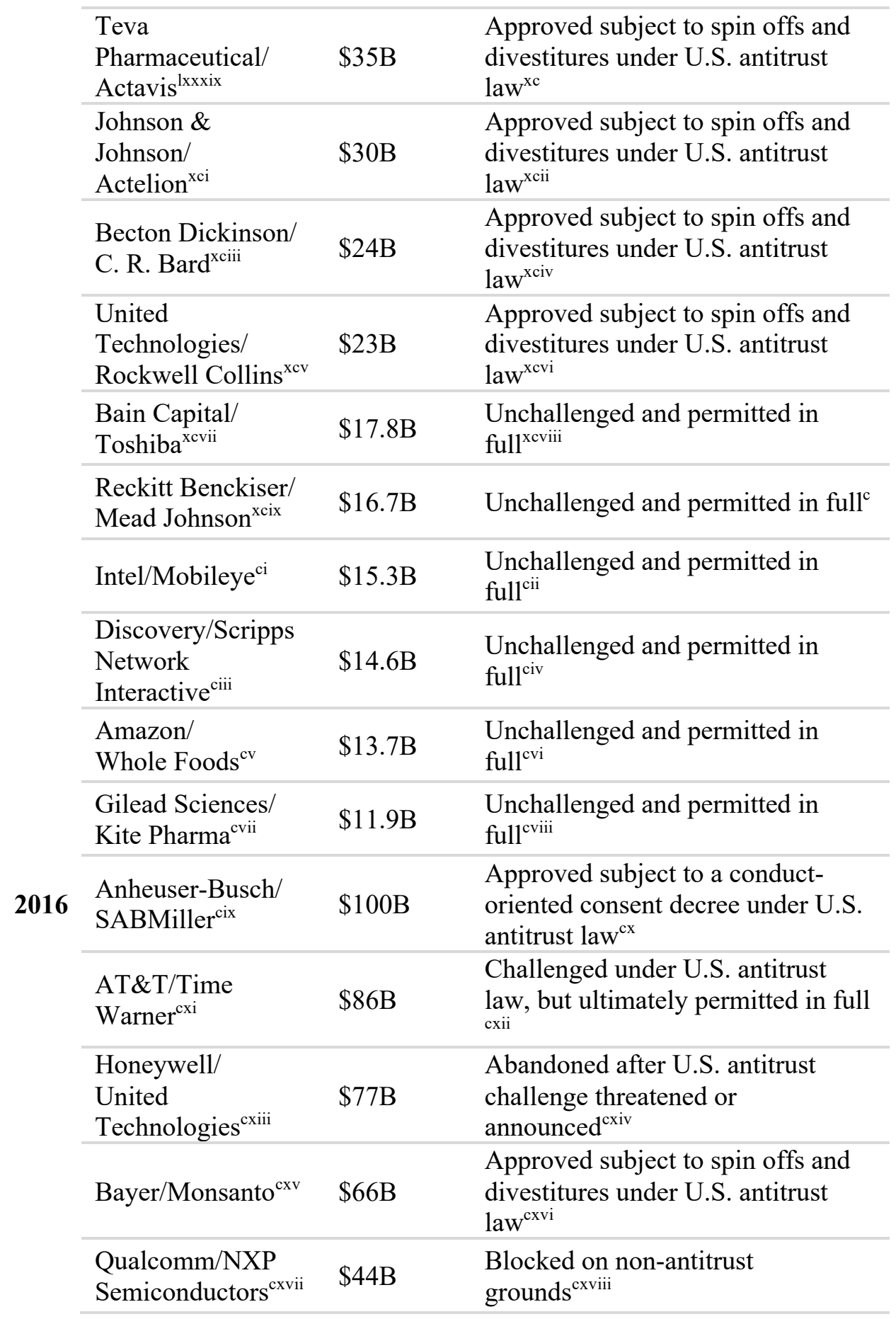




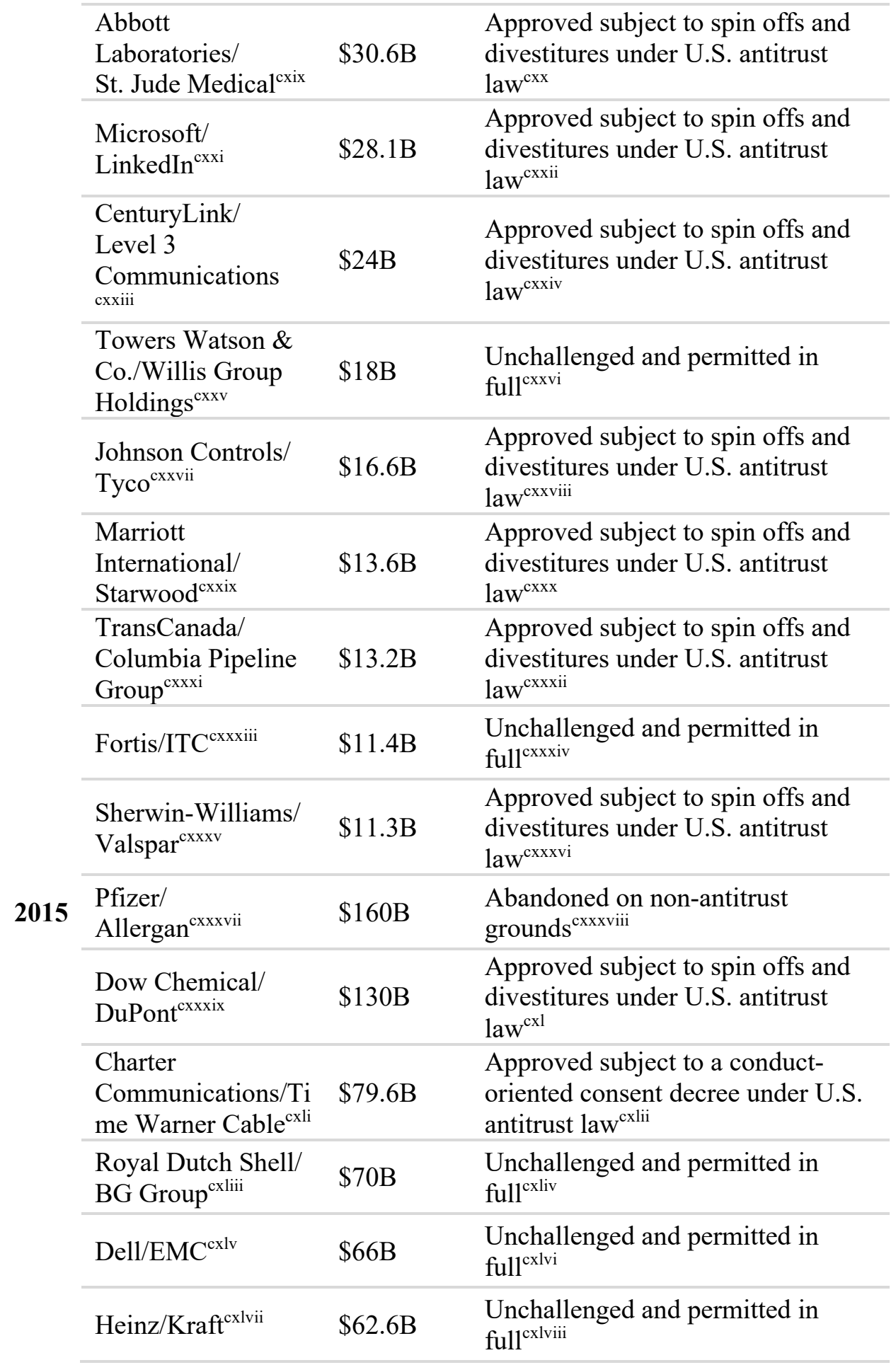




\begin{tabular}{|c|c|c|}
\hline Anthem/Cigna ${ }^{\text {cxlix }}$ & $\$ 55.2 \mathrm{~B}$ & $\begin{array}{l}\text { Blocked by a U.S. court on antitrust } \\
\text { grounds } \mathrm{s}^{\mathrm{cl}}\end{array}$ \\
\hline $\begin{array}{l}\text { Energy Transfer } \\
\text { Equity/Williams } \\
\text { Companies }^{\text {cli }}\end{array}$ & $\$ 55 \mathrm{~B}$ & $\begin{array}{l}\text { Approved subject to spin offs and } \\
\text { divestitures under U.S. antitrust } \\
\text { law }^{\text {clii }}\end{array}$ \\
\hline $\begin{array}{l}\text { British American } \\
\text { Tobacco/Reynolds } \\
\text { American }^{\text {cliii }^{2}}\end{array}$ & $\$ 49 B$ & $\begin{array}{l}\text { Unchallenged and permitted in } \\
\text { full }\end{array}$ \\
\hline $\begin{array}{l}\text { Berkshire } \\
\text { Hathaway/ } \\
\text { Precision } \\
\text { Castparts }^{\text {clv }}\end{array}$ & $\$ 37.2 \mathrm{~B}$ & $\begin{array}{l}\text { Unchallenged and permitted in } \\
\text { full }^{\text {clvi }}\end{array}$ \\
\hline Aetna/Humana ${ }^{\text {clvii }}$ & $\$ 37 \mathrm{~B}$ & $\begin{array}{l}\text { Blocked by a U.S. court on antitrust } \\
\text { grounds } \text { slviii }^{\text {cli }}\end{array}$ \\
\hline Mylan/Perrigo ${ }^{\text {clix }}$ & $\$ 35.3 \mathrm{~B}$ & $\begin{array}{l}\text { Approved subject to spin offs and } \\
\text { divestitures under U.S. antitrust } \\
\text { law }^{\text {clx }}\end{array}$ \\
\hline $\begin{array}{l}\text { Avago } \\
\text { Technologies/ } \\
\text { Broadcom }^{\text {clxi }}\end{array}$ & $\$ 32.3 \mathrm{~B}$ & $\begin{array}{l}\text { Unchallenged and permitted in } \\
\text { full }^{\text {clxii }}\end{array}$ \\
\hline Shire/Baxalta ${ }^{\text {clxiii }}$ & $\$ 32 B$ & $\begin{array}{l}\text { Unchallenged and permitted in } \\
\text { full }^{\text {clxiv }}\end{array}$ \\
\hline $\begin{array}{l}\text { AbbVie/ } \\
\text { Pharmacyclics }\end{array}$ & $\$ 21 \mathrm{~B}$ & $\begin{array}{l}\text { Unchallenged and permitted in } \\
\text { full }^{\text {clxvi }}\end{array}$ \\
\hline Pfizer/Hospira ${ }^{\text {clxvii }}$ & $\$ 17 \mathrm{~B}$ & $\begin{array}{l}\text { Approved subject to spin offs and } \\
\text { divestitures under U.S. antitrust } \\
\text { law }\end{array}$ \\
\hline Intel/Altera ${ }^{\text {clxix }}$ & $\$ 16.7 \mathrm{~B}$ & $\begin{array}{l}\text { Unchallenged and permitted in } \\
\text { full }\end{array}$ \\
\hline $\begin{array}{l}\text { NXP } \\
\text { Semiconductors/ } \\
\text { Freescale } \\
\text { Semiconductor }^{\text {clxxi }}\end{array}$ & $\$ 16.67 \mathrm{~B}$ & $\begin{array}{l}\text { Approved subject to spin offs and } \\
\text { divestitures under U.S. antitrust } \\
\text { law }^{\text {clxxii }}\end{array}$ \\
\hline $\begin{array}{l}\text { Valeant/Salix } \\
\text { Pharmaceuticals } \\
\text { clxxiii }\end{array}$ & $\$ 14.5 \mathrm{~B}$ & $\begin{array}{l}\text { Approved subject to spin offs and } \\
\text { divestitures under U.S. antitrust } \\
\text { law }^{\text {clxxiv }}\end{array}$ \\
\hline $\begin{array}{l}\text { Williams } \\
\text { Companies/ } \\
\text { Williams } \\
\text { Partners }\end{array}$ & $\$ 13.8 \mathrm{~B}$ & $\begin{array}{l}\text { Unchallenged and permitted in } \\
\text { full }^{\text {clxxvi }}\end{array}$ \\
\hline
\end{tabular}




\begin{tabular}{|c|c|c|}
\hline $\begin{array}{l}\text { Danaher } \\
\text { Corporation/Pall } \\
\text { Corporation }^{\text {clxxvii }}\end{array}$ & $\$ 13.8 \mathrm{~B}$ & $\begin{array}{l}\text { Unchallenged and permitted in } \\
\text { full }^{\text {clxxviii }}\end{array}$ \\
\hline $\begin{array}{l}\text { United Healthcare/ } \\
\text { Catamaran } \\
\text { clxxix }\end{array}$ & $\$ 12.8 \mathrm{~B}$ & $\begin{array}{l}\text { Unchallenged and permitted in } \\
\text { full }^{\text {clxxx }}\end{array}$ \\
\hline $\begin{array}{l}\text { CVS/ } \\
\text { Omnicare } \\
\text { clxxxi }\end{array}$ & $\$ 12.7 \mathrm{~B}$ & $\begin{array}{l}\text { Unchallenged and permitted in } \\
\text { full }^{\text {clxxxii }}\end{array}$ \\
\hline $\begin{array}{l}\text { Energy Transfer } \\
\text { Partners/ } \\
\text { Regency Energy } \\
\text { Partners }{ }^{\text {clxxxiii }}\end{array}$ & $\$ 11 B$ & $\begin{array}{l}\text { Unchallenged and permitted in } \\
\text { full }^{\text {clxxxiv }}\end{array}$ \\
\hline
\end{tabular}

i. Tobacco Giants Philip Morris, Altria Confirm Merger Talks, LAw360 (Aug. 27, 2019,

10:23 AM), https://www.law360.com/articles/1192869/tobacco-giants-philip-morris-altriaconfirm-merger-talks [https://perma.cc/G4JP-J9BZ].

ii. Daren Fonda, Altria and Philip Morris Called Off Their Merger. That's Good News for Both Stocks, BARRON's (Sept. 25, 2019, 1:59 PM), https://www.barrons.com/articles/why-theend-of-a-altria-philip-morris-merger-is-good-for-both-stocks-51569434373

[https://perma.cc/EKN4-KQ8J].

iii. 10 Biggest US Mergers \& Acquisitions Announced so far in 2019, AlPHASTREET (June 11, 2019), https://news.alphastreet.com/10-biggest-us-mergers-acquisitions-2019/ [https://perma.cc/GD8H-3G2D]; Bristol-Myers Squibb Market Cap 2006-2019, MACROTRENDS, https://www.macrotrends.net/stocks/charts/BMY/bristol-myers-squibb/market-cap [https://perma.cc/4T58-T29K].

iv. Bristol-Myers Will Cut Top Celgene Drug To Close \$74B Deal, LAw360 (June 24, 2019, 3:54 PM), https://www.law360.com/competition/articles/1172167/bristol-myers-will-cut-topcelgene-drug-to-close-74b-deal [https://perma.cc/8QV8-N9JY].

v. Ethel Jiang \& Arjun Reddy, Here Are the World's 10 Largest M\&A Deals this Year, Bus. INSIDER (Apr. 12, 2019, 4:06 PM), https://www.businessinsider.com/ma-largest-dealsworld-2019-2019-3 [https://perma.cc/3TGF-Y9V3]; Katie Warren, Saudi Arabia's Oil Company Is Now Worth a Record-Breaking \$2 Trillion. Meet Mohammed Bin Salman, the 34-year-old Crown Prince Who's at the Center of Human Rights Issues and Drops Millions on Yachts and Mansions, Bus. INSIDER (Dec. 12, 2019, 12:52 PM), https://www.businessinsider.com/mohammed-bin-salman-saudi-prince-net-worth-yacht-privatejet-lifestyle-2019-5 [https://perma.cc/E53Z-TZE8].

vi. Dan Murphy, Saudi Arabia's Sabic Plots a Course for its Future After Aramco's Planned IPO, CNBC (Oct. 28, 2019, 9:33 AM), https://www.cnbc.com/2019/10/28/sabic-plotsa-course-for-its-future-after-aramcos-planned-ipo.html [https://perma.cc/T8RP-CVR6].

vii. 4 Firms Guide AbbVie's \$63B Bet on Allergan, LAw360 (June 25, 2019, 8:08 AM), https://www.law360.com/mergersacquisitions/articles/1172561/4-firms-guide-abbvie-s-63b-beton-allergan [https://perma.cc/B7HP-7T2B]; AbbVie Market Cap 2010-2019, MACROTRENDS, https://www.macrotrends.net/stocks/charts/ABBV/abbvie/market-cap [https://perma.cc/9BF8FELA]. 
viii. Allergan Shareholders Approve Proposed Acquisition by AbbVie, CIsION (Oct. 14, 2019, 9:15 AM), https:/www.prnewswire.com/news-releases/allergan-shareholders-approveproposed-acquisition-by-abbvie-300937774.html [https://perma.cc/AYH4-MADT].

ix. 10 Biggest US Mergers \& Acquisitions Announced so far in 2019, supra note iii; Occidental Petroleum Marker Cap 2006-2019, MACROTRENDS, https://www.macrotrends.net/stocks/charts/OXY/occidental-petroleum/market-cap [https://perma.cc/VKG7-X4SS].

x. Oxy, Anadarko $\$ 38 B$ Merger Clears Antitrust Hurdle, OfFSHORE EnERGY TODAY (June 6, 2019), https://www.offshoreenergytoday.com/oxy-anadarko-38b-merger-clears-antitrusthurdle/ [https://perma.cc/T9QV-RLF3].

xi. Charles Tiefer, Merger of Defense Giants Raytheon and United Technologies Has its Downsides and Black Marks, ForBES (June 12, 2019, 12:34 PM), https://www.forbes.com/sites/charlestiefer/2019/06/12/merger-of-defense-giants-raytheon-andunited-technologies-has-its-downsides-and-black-marks/\#793f6d5214e8 [https://perma.cc/5PVU-DU83]; United Technologies Market Cap 2006-2019, MACROTRENDS, https://www.macrotrends.net/stocks/charts/UTX/united-technologies/market-cap [https://perma.cc/T5YJ-V2ZD].

xii. David Wichner, Raytheon, United Technologies Shareholders Approve Megamerger, AZCENTRAL (Oct. 12, 2019, 7:42 PM), https:/www.azcentral.com/story/news/local/arizonabreaking/2019/10/12/raytheon-united-technologies-shareholders-approvemegamerger/3966398002/ [https://perma.cc/55SR-T78U].

xiii. Paul A. Eisenstein, Fiat Chrysler, Peugeot Maker Ink \$50 Billion Merger, NBC NEWS (Dec. 18, 2019, 10:42 AM), https:/www.nbcnews.com/business/autos/fiat-chrysler-peugeotmaker-ink-50-billion-merger-n1103761 [https://perma.cc/BA5E-BLN2]; Fiat Chrysler Automobiles Market Cap 2014-2019, MACROTRENDS, https://www.macrotrends.net/stocks/charts/FCAU/fiat-chrysler-automobiles/market-cap [https://perma.cc/3RKU-8XPU].

xiv. Breana Noble, Fiat Chrysler, France's Groupe PSA Sign Binding Agreement To Merge,

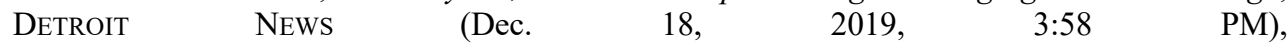
https:/www.detroitnews.com/story/business/autos/chrysler/2019/12/18/fiat-chrysler-fca-psagroupe-sign-binding-agreement-merge/2598512001/ [https://perma.cc/GT6M-Y8CG].

xv. Jiang \& Reddy, supra note v; Chevron Market Cap 2006-2019, MACROTRENDS, https://www.macrotrends.net/stocks/charts/CVX/chevron/market-cap [https://perma.cc/E4DC3UU2].

xvi. Avi Salzman, Chevron Actually Wins by 'Losing' the Contest To Buy Anadarko Petroleum, BARRON's (May 9, 2019, 9:42 PM), https://www.barrons.com/articles/chevronanadarko-occidental-mergers-51557430645 [https://perma.cc/K22E-CGB6].

xvii. Jiang \& Reddy, supra note v; Fiserv Market Cap 2006-2019, MACROTRENDS, https://www.macrotrends.net/stocks/charts/FISV/fiserv/market-cap [https://perma.cc/B5797KPA].

xviii.Fiserv-First Data Merger Is Complete, PYMNTS (July 29, 2019), https://www.pymnts.com/news/partnerships-acquisitions/2019/fiserv-first-data-mergercomplete/ [https://perma.cc/G6DT-L6X4].

xix. 10 Biggest US Mergers \& Acquisitions Announced so far in 2019, supra note iii; Fidelity National Information Services Market Cap 2006-2019, MACROTRENDS, https://www.macrotrends.net/stocks/charts/FIS/fidelity-national-information-services/marketcap [https://perma.cc/NJF5-P9XU]. 
xx. Foo Yun Chee, Exclusive: FIS To Win EU Approval for \$35 Billion Worldpay Deal: Sources, REUTERS (July 1, 2019, 10:43 AM), https://www.reuters.com/article/us-worldpy-m-afidelity-ntl-inf-eu-exclu/exclusive-fis-to-win-eu-approval-for-35-billion-worldpay-deal-sourcesidUSKCN1TW30F [https://perma.cc/4KU6-CKMS].

xxi. Richard Craver, Shareholders OK 'Truist' Name, BB\&T-SunTrust Merger by Wide Margin, Winston-SAlEM J. (July 2019), https://www.journalnow.com/business/shareholders-ok-truist-name-bb-t-suntrust-merger-bywide/article_000ba627-0f3e-5984-ad25-01fbe0e5d15b.html [https://perma.cc/HJE7-77WK]; 10 Biggest US Mergers \& Acquisitions Announced so far in 2019, supra note iii.

xxii. Lauren Ohnesorge, Feds Sign Off on \$66 Billion BB\&T-SunTrust Merger, WASHINGTON Bus. J. (Nov. $20, \quad 2019, \quad 2: 54 \quad 2$ PM), https://www.bizjournals.com/washington/news/2019/11/20/bb-t-suntrust-merger-earnsapproval-from-federal.html [https://perma.cc/C5CG-SNLY].

xxiii. London Stock Exchange Inks \$27B Deal for Refinitiv, LAw360 (Aug. 1, 2019, 7:44 AM), https:/www.law360.com/mergersacquisitions/articles/1183781/london-stock-exchange-inks27b-deal-for-refinitiv [https://perma.cc/AEZ5-8Z4F]. xxiv. Viren Vaghela, LSE Investors Bless \$27 Billion Refinitiv Deal in Key First Test, BloOMBERG (Nov. 26, 2019, 6:45 AM), https://www.bloomberg.com/news/articles/2019-1126/lse-investors-bless-27-billion-refinitiv-deal-in-key-first-test [https://perma.cc/FT47-UGRM]. xxv. The Charles Schwab Corporation To Acquire TD Ameritrade, CHARLES SCHWAB, https://www.aboutschwab.com/announcement [https://perma.cc/94D6-SW22]; Charles Schwab Market Cap 2006-2019, MACROTRENDS, https://www.macrotrends.net/stocks/charts/SCHW/charles-schwab/market-cap

[https://perma.cc/64FK-TZ8U].

xxvi. Maggie Fitzgerald, Charles Schwab To Buy TD Ameritrade in a \$26 Billion All-Stock Deal, CNBC (Nov. 25, 2019, 6:04 AM), https://www.cnbc.com/2019/11/25/charles-schwab-tobuy-td-ameritrade-in-a-26-billion-all-stock-deal.html [https://perma.cc/9FDY-FRXQ].

xxvii. 10 Biggest US Mergers \& Acquisitions Announced so far in 2019, supra note iii; Global Payments Market Cap 2006-2019, MACROTRENDS, https://www.macrotrends.net/stocks/charts/GPN/global-payments/market-cap [https://perma.cc/Y6PW-85WK].

xxviii. Philip Blenkinsop \& Francesco Guarascio, EU Clears Global Payments Purchase of Total Systems, REUTERs (Sept. 17, 2019, 10:02 AM), https:/www.reuters.com/article/us-tsys-m-a-global-payments-eu/eu-clears-global-paymentspurchase-of-total-systems-idUSKBN1W21O3 [https://perma.cc/UG6R-5NEF].

xxix. 10 Biggest US Mergers \& Acquisitions Announced so far in 2019, supra note iii; Danaher Market Cap 2006-2019, MACROTRENDS, https://www.macrotrends.net/stocks/charts/DHR/danaher/market-cap [https://perma.cc/7X3BSKDZ].

xxx. Danaher Selling Off Some Businesses to Sartorius for \$750M, Tying the Deal to GE Biopharma Acquisition, Genetic EngineERING \& Biotechnology News (Oct. 21, 2019), https://www.genengnews.com/news/danaher-selling-off-some-businesses-to-sartorius-for750m-tying-the-deal-to-ge-biopharma-acquisition/ [https://perma.cc/5KQX-9TEX].

xxxi. 10 Biggest US Mergers \& Acquisitions Announced so far in 2019, supra note iii;

Salesforce, Inc Market Cap 2006-2019, MACROTRENDS, https://www.macrotrends.net/stocks/charts/CRM/salesforce,-inc/market-cap [https://perma.cc/JSW7-FRR3]. 
xxxii. Todd Bishop, UK Regulators Finally Clear Salesforce and Tableau to Integrate, but Continue Review of \$15.7B Deal, GEEKWIRE (Nov. 5, 2019, 10:35 AM), https:/www.geekwire.com/2019/uk-authorities-finally-clear-salesforce-tableau-integratecontinue-antitrust-review-15-7b-deal/ [https://perma.cc/8SEP-NSGN].

xxxiii. Jiang \& Reddy, supra note v; Centene Market Cap 2006-2019, MACROTRENDS, https://www.macrotrends.net/stocks/charts/CNC/centene/market-cap [https://perma.cc/7AW5-AH8D].

xxxiv. Kelsey Waddill, Centene-WellCare Merger Prompts Sale of IL Medicaid and MA Plans, HeAlthPAyERINTELligence (Dec. 3, 2019), https://healthpayerintelligence.com/news/centene-wellcare-merger-prompts-sale-of-il-medicaidand-ma-plans [https://perma.cc/CV2J-QMHF].

xxxv.Sam Nussey, SoftBank to Create \$30 Billion Tech Giant Via Yahoo Japan, Line Corp Deal, ReUTERS (Nov. 17, 2019, 7:03 PM), https:/www.reuters.com/article/us-z-holdingsline/softbank-to-create-30-billion-tech-giant-via-yahoo-japan-line-corp-deal-

idUSKBN1XR0W5 [https://perma.cc/5PD7-WHWU]; Z Holdings Corporation, YAHOO!

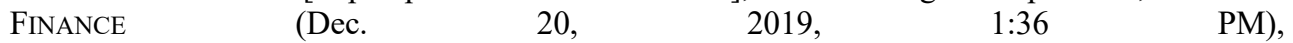
https://finance.yahoo.com/quote/YAHOF/?guccounter=1\&guce_referrer=aHR0cHM6Ly93d3cu Z29vZ2xILmNvbS8\&guce_referrer_sig=AQAAAJaK4cujfgzdRwM8H66hvjih5HKFüFNGOt1FxAK18vPmLACe4mOQgJuKJISpWHkPUkPBtbnBDy3 ysZOtqYNAIeLMxc3VfspXnIVfLc6A_gZny9b1BIK8pXYTynm3bCza8Tde6WghSOts31JNqlj IjmXob2bg2avaKIj44TR7L1 [https://perma.cc/8H3K-FEMD].

xxxvi. Catherine Shu, Yahoo Japan and Line Corp. Confirm Merger Agreement, TECHCRUNCH (Nov. 18, 2019, 12:00 AM), https://techcrunch.com/2019/11/17/yahoo-japan-andline-corp-confirm-merger-agreement/ [https://perma.cc/U6JF-5XFH].

xxxvii. Jonathan Berr, Here is Everything You Need to Know About the Viacom-CBS Merger, FORBES (Nov. 26, 2019, 2:35 https:/www.forbes.com/sites/jonathanberr/2019/11/26/here-is-everything-you-need-to-knowabout-the-viacom-cbs-merger/\#425efff5147d [https:/perma.cc/E85Y-4KY7]; Dawn Chmielewski, CBS and Viacom Announce Plans to Merge, Finally Fulfilling Shari Redstone's Dream on 3rd Try, Forbes (Aug. 13, 2019, 2:18 PM), https://www.forbes.com/sites/dawnchmielewski/2019/08/13/cbs-viacom-merger-shariredstone/\#1a314b341a8e [https://perma.cc/H3N9-PSAV].

xxxviii. David Folkenflik, Viacom and CBS Agree to Merge in \$30B Deal, NPR (Aug. 13, 2019, 4:50 PM), https://www.npr.org/2019/08/13/750896132/viacom-and-cbs-agree-tomerge-in-30-billion-deal [https://perma.cc/KRG7-7WLF].

xxxix. Pfizer to Acquire Array BioPharma, Pfizer (Jun. 17, 2019, 6:45 AM), https://www.pfizer.com/news/press-release/press-release-

detail/pfizer_to_acquire_array_biopharma [https://perma.cc/M2BY-73KX]; Pfizer Market Cap 2006-2019, MACROTRENDS, https://www.macrotrends.net/stocks/charts/PFE/pfizer/market-cap [https://perma.cc/3WB3-DKUM].

xl. Pfizer Completes Acquisition of Array Biopharma, Bloomberg (Jul. 30, 2019, 5:16 AM), https://www.bloomberg.com/press-releases/2019-07-30/pfizer-completes-acquisition-ofarray-biopharma [https://perma.cc/CE6S-FXWC].

xli. AB InBev Inks \$11.3B Sale of Australian Unit to Asahi Group, LAw360 (Jul. 19, 2019, 7:52 AM), https:/www.law360.com/mergersacquisitions/articles/1180048/ab-inbev-inks-11-3bsale-of-australian-unit-to-asahi-group [https://perma.cc/BH3U-BB7P]; \#520 Asahi Group Holdings, ForBES (May 15, 2019), https:/www.forbes.com/companies/asahi-groupholdings/\#4e3b60707727 [https://perma.cc/4ZFU-ML96]. 
xlii. Darren Gray, Asahi's \$16B Takeover of CUB Raises Competition Concerns, Says ACCC, SYNDEY MORNING Herald (Dec. 12, 2019, 10:12 AM), https://www.smh.com.au/business/companies/asahi-s-16b-takeover-of-cub-raises-competitionconcerns-says-accc-20191212-p53j88.html [https://perma.cc/EML4-BWUE].

xliii. 3 Firms Guide Broadcom's \$10.7B Symantec Biz Buy, LAw360 (Aug. 8, 2019, 4:39 PM), https:/www.law360.com/mergersacquisitions/articles/1186877/3-firms-guide-broadcoms-10-7b-symantec-biz-buy [https://perma.cc/KQA8-FCVH]; Broadcom Market Cap 2009-2019, MACROTRENDS, https://www.macrotrends.net/stocks/charts/AVGO/broadcom/market-cap [https://perma.cc/LP6M-EP3Y].

xliv. Jason Aycock, Broadcom Gets Early HSR Termination for Symantec Deal, SEEKING AlPHA (Sep. 3, 2019, 12:35 PM), https://seekingalpha.com/news/3496435-broadcom-gets-earlyhsr-termination-for-symantec-deal [https://perma.cc/2WFE-XHFH].

xlv. Jiang \& Reddy, supra note v.

xlvi. Marcia Heroux Pounds, Ultimate Softward Gets Green Light to Proceed With \$11 Billion Sale, South Florida Sun SEnTINel (Feb. 27, 2019), https://www.sunsentinel.com/business/fl-bz-ultimate-software-ftc-clearance-20190227-story.html [https://perma.cc/MX6A-ABVE].

xlvii. 10 Biggest US Mergers \& Acquisitions Announced so far in 2019, supra note iii; Newmont Goldcorp Market Cap 2006-2019, MACROTRENDS, https:/www.macrotrends.net/stocks/charts/NEM/newmont-goldcorp/market-cap [https://perma.cc/2JN9-VKQ9].

xlviii. Tom Palmer, Newmont Mining and Goldcorp Receive Merger Approval from the Government of Korea, Junior MinING NeTwORK, https:/www.juniorminingnetwork.com/junior-miner-news/press-releases/1101nyse/nem/58735-newmont-mining-and-goldcorp-receive-merger-approval-from-thegovernment-of-korea.html [https://perma.cc/NG9B-5HJQ].

xlix. FactSet Research Systems InC., FactSet Flashwire US Monthly (Jan. 2019), https://www.factset.com/hubfs/mergerstat_em/monthly/US-Flashwire-Monthly.pdf [https://perma.cc/U43N-FMQX]; Joe Ciolli, It's Official: T-Mobile and Sprint Are Coming Together to Form a $\$ 146$ Billion New Company to Take on Verizon and AT\&T, BUSINESS INSIDER (Apr. 30, 2018, 7:44 AM), https://www.businessinsider.com/t-mobile-and-sprint-merger-termsdetails-2018-4 [https://perma.cc/DMA7-VK6U].

1. Ambrish Shah, T-Mobile-Sprint Merger Antitrust Trial Ends Positively, MARKET REALIST (Dec. 21, 2019), https://marketrealist.com/2019/12/t-mobile-sprint-merger-antitrusttrial-ends-positively/ [https://perma.cc/PS22-LB9Y].

li. FACTSET RESEARCH SYSTEMS INC., supra note xlix; Cigna \#328 Best Employers for Diversity 2019, ForBes (May 2019 ), https://www.forbes.com/companies/cigna/\#4c050ada9742 [https://perma.cc/8JUJ-Y4HP].

lii. Carolina Humer, Cigna Says Express Scripts Acquisition Passes Antitrust Review, Ins. J. (Sept. 17, 2018), https://www.insurancejournal.com/news/national/2018/09/17/501561.htm [https://perma.cc/AP5S-J39A].

liii. Samuel Stebbins, The 10 Biggest Mergers and Acquisitions of 2018, USA TODAY (Dec. 10, 2018, 6:00 AM), https://www.usatoday.com/story/money/business/2018/12/10/mergers-andacquisitions-2018-10-biggest-corporate-consolidations/38666639/] [https://perma.cc/62W6GAMR]; Energy Transfer Equity, FORTUNE, http://fortune.com/fortune500/energy-transferequity/ (last visited Dec. 17, 2019).

liv. Pranav Ghumatkar, Energy Transfer Equity and Energy Transfer Partners Complete Merger, Simplify Structure, SEEKING AlpHA (Oct. 19, 2018, 2:45 PM), 
https://seekingalpha.com/news/3399017-energy-transfer-equity-energy-transfer-partners-

complete-merger-simplify-structure [https://perma.cc/Y65U-5LKN].

lv. FaCtSet ReSEARCh Systems InC., supra note xlix; Comcast \#82 Best Employers for Diversity 2019, ForBES (May 15, 2019), https://www.forbes.com/companies/comcast/\#4d87c4a752c1 [https://perma.cc/F2HC-NTRC].

lvi. Georg Szalai \& Etan Vlessing, Comcast Closes Deal for Fox's Sky Holding, Giving It Majority Stake, THE HOLlywOOD REPORTER (Oct. 9, 2018), https:/www.hollywoodreporter.com/news/comcast-closes-acquisition-fox-s-sky-holdinggiving-it-majority-stake-1148530 [https://perma.cc/GR86-C47L].

lvii. 3 Firms Steer IBM's \$34B Red Hat Acquisition, LAw360 (Oct. 28, 2018), https://www.law360.com/mergersacquisitions/articles/1096434/3-firms-steer-ibm-s-34b-redhat-acquisition [https://perma.cc/9RGK-STJB]; IBM \#20 America's Largest Public Companies, FORBES (May 15, 2019), https://www.forbes.com/companies/ibm/?list=top-publiccompanies\#49692d8a39c4 [https://perma.cc/9FDX-6F6X].

lviii. Another Step Closer: EU Approves \$34B IBM-Red Hat Merger, WRAL TECHWIRE (Jun. 27, 2019), https:/www.wraltechwire.com/2019/06/27/eu-approves-ibm-red-hat-merger/ [https://perma.cc/KD3A-27JL].

lix. FactSet Research Systems Inc., supra note xlix; Marathon Petroleum \#89 Best Employers for Diversity 2019, FORBES (Jun. 6, 2018), https://www.forbes.com/companies/marathon-petroleum/\#37d9e9701732

[https://perma.cc/KKE5-WYJW].

lx. Matt Sanctis, FTC Requires Marathon to Sell Stores to Avoid Antitrust Problems, SPRINGFIELD NEws-Sun (Oct. 30, 2018), https:/www.springfieldnewssun.com/news/local/ftcrequires-marathon-sell-stores-avoid-antitrust-problems/DFzK3iFLZVca116WbcCUCO/ [https://perma.cc/N5TA-R9BC].

1xi. Broadcom to Acquire CA Technologies for \$18.9 Billion in Cash, BROADCOM (Jul. 11 , 2018), https://www.ca.com/us/company/newsroom/press-releases/2018/broadcom-toacquire-ca-technologies-for-18-9-billion-in-cash.html [https://perma.cc/FD9G-TGX7]; Broadcom \#11 Top 100 Digital Companies 2019, ForBES (May 15, 2019), https://www.forbes.com/companies/broadcom/?list=top-public-companies\#356580267830 [https://perma.cc/5LDR-LYQN].

lxii. Jason Aycock, Broadcom Gets Antitrust OK on Acquisition of CA, SEeKING AlPHA (Aug. 24, 2018, 9:27 AM), https://seekingalpha.com/news/3385570-broadcom-gets-antitrust-okacquisition-ca [https://perma.cc/HR72-LWV3].

lxiii. 3 Firms Steer \$35B Harris-L3 Technologies Tie-Up, LAw360 (Oct. 14, 2018, 2:40 PM), https://www.law360.com/mergersacquisitions/articles/1092085/3-firms-steer-35b-harris-13-

technologies-tie-up [https://perma.cc/KA7X-JQH2]; Harris \#188 Best Employer for New Grads 2018, FORBES (Jun. 6, 2018), https://www.forbes.com/companies/harris/\#4ff307a59774 [https://perma.cc/3C27-SGNK].

lxiv. Harris Corporation and L3 Technologies Set Closing Date for Merger, L3HARRIS (June 21, 2019), https://www.harris.com/press-releases/2019/06/harris-corporation-and-13technologies-set-closing-date-for-merger [https://perma.cc/7AAA-BALC].

lxv. FactSet ReSEARch Systems Inc., supra note xlix; Keurig Green Mountain \#43 World's Most Innovative Companies 2015, Forbes (May 6, 2015), https://www.forbes.com/companies/keurig-green-mountain/\#4b399be558ec

[https://perma.cc/JEJ4-CF2X]. 
lxvi. Hunger for Food and Bev M\&A May Cause Antitrust Concerns, LAW360 (Jan. 31, 2018, 6:36 PM), https://www.law360.com/articles/1007309/hunger-for-food-and-bev-m-a-may-causeantitrust-concerns [https://perma.cc/M56E-6J3S].

lxvii. Stebbins, supra note liii; Thomas Reuters \# 446 Best Employers for Diversity 2019, FORBES (May 15, 2018), https://www.forbes.com/companies/thomson-reuters/\#5431b2a92630 [https://perma.cc/3NXB-C988].

lxviii. Thomson Reuters and Blackstone Close Financial \& Risk Transaction, THOMSON REUTERS (Oct. 1, 2018), https://www.thomsonreuters.com/en/pressreleases/2018/october/thomson-reuters-and-blackstone-close-financial-and-risk-transaction.html [https://perma.cc/CQN3-JU43].

lxix. FactSet Research Systems InC., supra note xlix; Walmart \#236 World's Best Employers 2018, Forbes (May 2018), https://www.forbes.com/companies/walmart/\#63535a57b03d [https://perma.cc/98RW-9DDC].

lxx. Jon Russell, Walmart Completes its \$16 Billion Acquisition of Flipkart, TECHCRUNCH (Aug. 20, 2018), https://techcrunch.com/2018/08/20/walmart-flipkart-deal-done/ [https://perma.cc/5DQV-5ZQW].

lxxi. Cravath, Debevoise Guide AXA's \$15.3B Deal for XL Group, LAw360 (Mar. 5, 2018, 2:33 PM), https://www.law360.com/mergersacquisitions/articles/1018308/cravath-debevoiseguide-axa-s-15-3b-deal-for-xl-group [https://perma.cc/YM9N-34MS]; AXA Group \#65 Top Regarded Companies 2018, ForBES (Jun. 6, 2018), https://www.forbes.com/companies/axagroup/?list=top-public-companies\#2a4abd4d34ab [https://perma.cc/QN6E-SBFT].

lxxii. Matthew Lerner, AXA Completes \$15B Acquisition of XL Group, Ratings Upgraded,

BUSINESS INSURANCE (Sept. 12,
https://www.businessinsurance.com/article/00010101/NEWS06/912323959/Axa-completes\$15B-acquisition-of-XL-Group,-ratings-upgraded [https://perma.cc/Q5VM-TAXG].

lxxiii. FACTSET ReSEARCH SySTEMS INC., supra note xlix; Dominion Resources \#90 America's Largest Public Companies 2018, Forbes (May 15, 2018), https://www.forbes.com/companies/dominion-resources/?list=top-publiccompanies\#89c36d24b01f [https://perma.cc/E6TW-2RVK].

lxxiv. Dominion and SCANA Complete Merger, World NuClEAR News (Jan. 3, 2019), http://www.world-nuclear-news.org/Articles/Dominion-and-Scana-complete-merger [https://perma.cc/AND7-5VNC].

lxxv. Shelia Kaplan \& Matt Richtel, Juul Closes Deal with Tabacco Giant Altria, N.Y. TIMES (Dec. 20, 2018), https://www.nytimes.com/2018/12/20/health/juul-reaches-deal-with-tobaccogiant-altria.html [https://perma.cc/9H43-GAZ2]; Altria Market Cap 2006-2019, MACROTRENDS, https://www.macrotrends.net/stocks/charts/MO/altria/market-cap [https://perma.cc/P89R-2864].

lxxvi. Angelica LaVito, Altria Confirms FTC Investigation of Juul as Agency Scrutinizes Role in Executive Shake-UP at Vaping Company, CNBC (Oct. 31, 2019, 2:11 PM), https://www.cnbc.com/2019/10/31/altria-confirms-ftc-probe-of-juul-as-agency-scrutinizesexecutive-shakeup.html [https://perma.cc/4C98-98H9].

lxxvii. Sanofi Buys Hemophilia Drugmaker in \$11.6B Deal, LAw360 (Jan. 22, 2018, 7:53 AM), https://www.law360.com/mergersacquisitions/articles/1004157/sanofi-buyshemophilia-drugmaker-in-11-6b-deal [https://perma.cc/RN42-E69E]; Sanofi \#336 World's Best Employers 2018, FORBES (May 15, 2018), https://www.forbes.com/companies/sanofi/\#47b129511fde [https://perma.cc/5R84-3XY7].

lxxviii. Sanofi Gets U.S. Regulatory Approval for Proposed Acquisition of Bioverativ, $\begin{array}{lllll}\text { MARKETS } & \text { INSIDERS } & \text { 23, 2018, } & \text { 4:21 }\end{array}$ 
https://markets.businessinsider.com/news/stocks/sanofi-gets-u-s-regulatory-approval-forproposed-acquisition-of-bioverativ-1016828665 [https://perma.cc/SS24-47EH].

lxxix. $\quad$ Conagra Brands to Acquire Pinnacle Foods for $\$ 10.9$ Billion in Cash and Stock, CONAGRA BRANDS (Jun. 27, 2018), https://www.conagrabrands.com/news-room/newsconagra-brands-to-acquire-pinnacle-foods-for-109-billion-in-cash-and-stock-prn-122635

[https://perma.cc/VZ54-UYY8]; Conagra Brands \#294 America's Largest Public Companies, FORBES (May 15, 2018), https://www.forbes.com/companies/conagra-brands/?list=top-publiccompanies\#21d97a235160 [https://perma.cc/BM9Y-J4UB].

lxxx. Conagra Brands and Pinnacle Foods Announce Expiration of HSR Act Waiting Period, CONAGRA (Aug. 23, 2018), https://www.conagrabrands.com/news-room/news-conagra-brandsand-pinnacle-foods-announce-expiration-of-hsr-act-waiting-period-prn-122642

[https://perma.cc/7TTC-ZTQ3].

lxxxi. Broadcom Proposes to Acquire Qualcomm for $\$ 70.00$ per Share in Cash and Stock in Transaction Valued at \$130 Billion, PR NewswiRE (Nov. 6, 2017), https://www.prnewswire.com/news-releases/broadcom-proposes-to-acquire-qualcomm-for7000-per-share-in-cash-and-stock-in-transaction-valued-at-130-billion-300549895.html [https://perma.cc/M8NM-XLKE].

lxxxii. Cecilia Kang \& Alan Rappeport, Trump Blocks Broadcom's Bid for Qualcomm, N.Y. TIMES (Mar. 2018), https://www.nytimes.com/2018/03/12/technology/trump-broadcom-qualcomm-merger.html [https://perma.cc/4DEV-AN6M].

lxxxiii. Madeleine Johnson, 15 of the Best Mergers \& Acquisitions of 2017, NASDAQ (Dec. 29, 2017, 11:39 AM), https://www.nasdaq.com/article/15-of-the-best-mergersacquisitions-of-2017-cm898464 [https://perma.cc/EJC4-S5AH]; CVS Health Market Cap 20062019, MACROTRENDS, https://www.macrotrends.net/stocks/charts/CVS/cvs-health/market-cap [https://perma.cc/KXW5-RUDQ] [hereinafter MACROTRENDS, CVS Health Market Cap]; Disney Market Cap 2006-2019, MACROTRENDS, https://www.macrotrends.net/stocks/charts/DIS/disney/market-cap [https://perma.cc/VA9F48M2].

lxxxiv. Josh Kosman \& Richard Morgan, DOJ May Allow Disney to Spin Off Fox's Regional Sports Networks, N.Y. Post (Jan. 14, 2019, 10:41 PM), https://nypost.com/2019/01/14/doj-may-allow-disney-to-spin-off-of-foxs-regional-sportsnetworks/ [https://perma.cc/KUM7-GUDZ].

lxxxv. Johnson, supra note lxxxiii; MACROTRENDS, CVS Health Market Cap, supra note lxxxiii.

lxxxvi. Nathaniel Weixel, Judge Adds New Hurdle to CVS-Aetna Merger, HiLl (Dec. 6, 2018, 6:00 AM), https://thehill.com/business-a-lobbying/419971-judge-adds-new-hurdle-tocvs-aetna-merger [https://perma.cc/97ZS-HSCT].

lxxxvii. Chelsea Naso, Linde, Praxair Fine-Tune Plans For \$65B Combination,

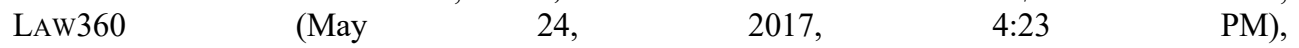
https://www.law360.com/mergersacquisitions/articles/927841/linde-praxair-fine-tune-plans-for65b-combination [https://perma.cc/5JUF-9UTH]; Linde Aktiengesellschaft, YAHOO! FINANCE, https://finance.yahoo.com/quote/LNAGF?p=LNAGF\&.tsrc=fin-srch [https://perma.cc/U66ZJKY7].

1xxxviii. Oliver Sachgau \& David McLaughlin, Linde, Praxair Win U.S. Antitrust Nod to Create Gas Giant, BloOMBERG (Oct. 22, 2018, 8:48 AM), https:/www.bloomberg.com/news/articles/2018-10-22/linde-praxair-win-u-s-antitrust-nod-tocreate-gas-giant [https://perma.cc/DPS4-F5GQ]. 
lxxxix. Jon Hill, Teva Hit With Investor Suit Over \$40.5B Actavis Merger, LAw360 (Aug. 30, 2017, 8:19 PM), https://www.law360.com/mergersacquisitions/articles/959349/tevahit-with-investor-suit-over-40-5b-actavis-merger [https://perma.cc/32JQ-QKRE]; Teva Pharmaceutical Industries Market Cap 2006-2019, MACROTRENDS, https://www.macrotrends.net/stocks/charts/TEVA/teva-pharmaceutical-industries/market-cap [https://perma.cc/5DK9-5GKW].

xc. Teva Completes Acquisition of Actavis Generics, Bus. WIRE (Aug. 2, 2016, 1:13 PM), https:/www.businesswire.com/news/home/20160802006666/en/Teva-Completes-AcquisitionActavis-Generics [https://perma.cc/2Q47-LX2G].

xci. Matthew Guarnaccia, EU Approves J\&J's \$30B Actelion Buy, With Conditions, $\begin{array}{lllll}\text { LAw360 (Jun. } & 9, & 2017, & \text { PM), }\end{array}$ https://www.law360.com/mergersacquisitions/articles/933024/eu-approves-j-j-s-30b-actelionbuy-with-conditions [https://perma.cc/F982-9MDF]; Johnson \& Johnson Market Cap 20062019, MACROTRENDS, https:/www.macrotrends.net/stocks/charts/JNJ/johnson-johnson/marketcap [https://perma.cc/2XP7-RNKV].

xcii. Update: All Regulatory Approvals Required to Complete Acquisition of Actelion Received, PHARMA LETTER (Sept. 6, 2017), https://www.thepharmaletter.com/article/allregulatory-approvals-required-to-complete-acquisition-of-actelion-received [https://perma.cc/N6LR-TJ6X].

xciii. Matthew Perlman, EU Accepts Becton Dickinson's Fixes for \$24B Bard Buy, LAw360 (Oct. 18, 2017, 3:45 PM), https://www.law360.com/mergersacquisitions/articles/975684/euaccepts-becton-dickinson-s-fixes-for-24b-bard-buy [https://perma.cc/W4QM-QXRP]; Becton Dickinson Market Cap 2006-2019, MACROTRENDS, https://www.macrotrends.net/stocks/charts/BDX/becton-dickinson/market-cap

[https://perma.cc/M7ZZ-2293].

xciv. Becton, Dickinson to Divest Two Product Lines for C R Bard Buy: FTC, REUTERS (Dec. 22, 2017, 12:49 PM), https:/www.reuters.com/article/uk-cr-bard-m-a-bd-usa/becton-dickinsonto-divest-two-product-lines-for-c-r-bard-buy-ftc-idUSKBN1EG26L］[https://perma.cc/SGK3HJFE].

xcv. Johnson, supra note 1xxxiii; United Technologies Market Cap 2006-2019, MACROTRENDS, https://www.macrotrends.net/stocks/charts/UTX/united-technologies/marketcap [https://perma.cc/ZS8F-AFMJ].

xcvi. United Technologies Announces Intention to Separate into Three Independent Companies; Completes Acquisition of Rockwell Collins, United TECHNOLOGIES (Nov. 26, 2018), http://www.utc.com/News/News-Center/Pages/United-Technologies-Announces-Intention-toSeparate-Into-Three-Independent-Compan.aspx [https://perma.cc/XLN3-XAP7].

xcvii.Benjamin Horney, Toshiba Stands by Ability to Close \$17.8B Memory Biz Sale, LAw360 (Oct. 4, 2017, 2:37 PM), https://www.law360.com/mergersacquisitions/articles/971280/toshibastands-by-ability-to-close-17-8b-memory-biz-sale [https://perma.cc/4ZCH-WHHU]; About Us, BAIN CAPITAL, https://www.baincapital.com/about-us [https://perma.cc/N7UK-JNE2]. xcviii. Bain Capital Closes $\$ 18 B$ Deal for Toshiba's Memory Chip Division, PIтснBоoK (Jun. 4, 2018), https://pitchbook.com/newsletter/bain-capital-closes-18b-deal-fortoshibas-memory-chip-division [https://perma.cc/NQU6-6AEM].

xcix. Chelsea Naso, Mead Johnson Confirms \$16.7B Bid from Reckitt Benckiser, LAw360 (Feb. 2, 2017, 3:31 PM), https://www.law360.com/mergersacquisitions/articles/887626/meadjohnson-confirms-16-7b-bid-from-reckitt-benckiser [https://perma.cc/C3DL-M5F8]; Reckitt Benckiser Group, YAHOO! FIN., https://finance.yahoo.com/quote/RB.L?p=RB.L\&.tsrc=fin-srch [https://perma.cc/5NGY-T74T]. 
c. Mead Johnson Nutrition Merger with Reckitt Benckiser Completed, MEAD JoHNSON (Jun. 15, 2017), https:/www.meadjohnson.com/news/press-releases/mead-johnson-nutritionmerger-reckitt-benckiser-completed [https://perma.cc/FW68-V887].

ci. Johnson, supra note lxxxiii; Intel Market Cap 2006-2019, MACROTRENDS, https://www.macrotrends.net/stocks/charts/INTC/intel/market-cap [https://perma.cc/X4UB2DXX].

cii. Mallory Locklear, Intel's Acquisition of Mobileye is Officially Complete, ENGADGET (Aug. 8, 2017), https://www.engadget.com/2017/08/08/intel-acquisition-mobileye-complete/ [https://perma.cc/HT66-SFZE].

ciii. Johnson, supra note 1xxxiii; Discovery Communications Market Cap 2006-2019, MACROTRENDS, https://www.macrotrends.net/stocks/charts/DISCB/discoverycommunications/market-cap [https://perma.cc/J4FN-TZEJ].

civ. Andrew Metcalf, Federal Government Clears Discovery's Acquisition of Scipps, Bethesda MAgazine (Feb. 27, 2018, 9:40 AM), https://bethesdamagazine.com/bethesdabeat/business/federal-government-clears-discoverys-acquisition-of-scripps/

[https://perma.cc/P34J-C6MJ].

cv. Johnson, supra note lxxxiii; Amazon Market Cap 2006-2019, MACROTRENDS, https:/www.macrotrends.net/stocks/charts/AMZN/amazon/market-cap [https://perma.cc/J2YLKURV].

cvi. David McLaughlin \& Spencer Soper, Amazon's Whole Foods Deals Wins Swift U.S. Antitrust Approval, BlOOMBerG (Aug. 23, 2017, 1:35 PM), https://www.bloomberg.com/news/articles/2017-08-23/amazon-s-whole-foods-deal-wins-fasttrack-u-s-antitrust-nod [https://perma.cc/J8W9-BDVJ].

cvii. Johnson, supra note lxxxiii; Gilead Sciences Market Cap 2006-2019, MACROTRENDS, https://www.macrotrends.net/stocks/charts/GILD/gilead-sciences/market-cap

[https://perma.cc/6QLD-E54W].

cviii. Gilead Sciences, Kite Pharma Announce Expiration of HSR Waiting Period,

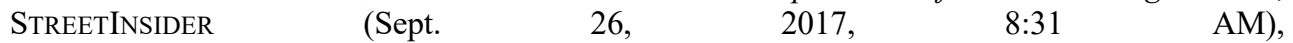
https:/www.streetinsider.com/Corporate+News/Gilead+Sciences+\%28GILD $\% 29 \% 2 \mathrm{C}+\mathrm{Kite}+\mathrm{P}$ harma+\%28KITE $\% 29+$ Announce+Expiration+of+HSR+Waiting + Period/13327911.html [https://perma.cc/QYE3-6P45].

cix. Matthew Guarnaccia, Consumer Groups Weigh in on \$100B InBev, SABMiller Deal, $\begin{array}{lllll}\text { LAw360 (Jun. } & 7, & 2017, & 8: 00 & \text { PM), }\end{array}$ https:/www.law360.com/mergersacquisitions/articles/932256/consumer-groups-weigh-in-on100b-inbev-sabmiller-deal [https://perma.cc/7GM9-RPKT]; Anheuser-Busch Market Cap 20072019, MACROTRENDS, https:/www.macrotrends.net/stocks/charts/BUD/anheuser-busch/marketcap [https://perma.cc/JVB6-434N].

cx. Keith Gribbins, AB InBev Purchase of SABMiller is Finally Approved; Here Are the Important Modifications, CRAFT BREWING Business (Oct. 30, 2018), https:/www.craftbrewingbusiness.com/business-marketing/ab-inbev-purchase-of-sabmiller-isfinally-approved-here-are-the-important-modifications/ [https://perma.cc/72YN-55N2].

cxi. Marguerite Reardon, AT\&T Gets to Buy Time Warner in Legal Win Over Justice Department, CNET (Jun. 12, 2018, 6:47 PM), https://www.cnet.com/news/at-t-gets-to-buy-timewarner-in-legal-win-over-justice-department/ [https://perma.cc/JU82-LMH2]; Lucinda Shen, Here Are the 5 Biggest M\&A Deals of 2016, ForTunE (Dec. 28, 2016, 7:00 AM), http://fortune.com/2016/12/28/mergers-and-acquisitions-donald-trump/; AT\&T Market Cap 2006-2019, MACROTRENDS, https://www.macrotrends.net/stocks/charts/T/at-t/market-cap [https://perma.cc/9YBZ-BTTH]. 
cxii. Hadas Gold, Appeals Court Back AT\&T Acquisition of Time Warner, CNN (Feb. 27, 2019, 5:02 PM), https:/www.cnn.com/2019/02/26/media/att-time-warner-mergerruling/index.html [https://perma.cc/B4JR-M9VD].

cxiii. Ankit Ajmera \& Andrea Shalal, United Tech Rejects Honeywell's \$90.7 Billion Offer, REUTERS (Feb. 26, 2016, 7:30 AM), https://www.reuters.com/article/us-unitedtech-m-ahoneywell-idUSKCN0VZ1X7 [https://perma.cc/75S5-FQS3]; Honeywell Market Cap 20062019, MACROTRENDS, https://www.macrotrends.net/stocks/charts/HON/honeywell/market-cap [https://perma.cc/NG8R-RBZU].

cxiv. Ted Mann, Honeywell Ends Chase for United Technologies, Wall STREeT J. (Mar. 1, 2016, 7:14 PM), https://www.wsj.com/articles/honeywell-ends-pursuit-of-united-technologies1456841533 [https://perma.cc/KM3D-XTPJ].

cxv. Shen, supra note cxi; \#273 Bayer World's Best Employers List, ForBES (May 15, 2019), https:/www.forbes.com/companies/bayer/\#5c2e6fff7965 [https://perma.cc/SLC3-QE92]; See also Another Record Year for Bayer-Good Progress with the Acquisition of Monsanto, Annual Report 2016, BAYER, https:/www.annualreport2016.bayer.com/at-a-glance/fiscal-year2016.html\#/datasheet-bayer_ar_oekonomisch/vertbar/0/0,1,2,3,4/figures/0

[https://perma.cc/F5JW-72XC].

cxvi. Activists to German Gov't: 'Challenge Bayer Monsanto Merger,' TELESUR (May 26, 2018), https:/www.telesurenglish.net/news/Activists-to-German-Govt-Challenge-BayerMonsanto-Merger-20180526-0013.html [https://perma.cc/N7AE-DUVP].

cxvii. Shen, supra note cxi; Qualcomm Market Cap 2006-2019, MACROTRENDS, https://www.macrotrends.net/stocks/charts/QCOM/qualcomm/market-cap

[https://perma.cc/E8KW-F7SB].

cxviii. $\quad$ Ellen Proper, NXP CEO Blames Politics for No Qualcomm Merger, Will Avoid Deals, BloOmberg (Jul. 26, 2018, 2:50 AM), https:/www.bloomberg.com/news/articles/201807-26/nxp-to-buy-back-5-billion-of-shares-as-qualcomm-deal-collapses

[https://perma.cc/DE2N-RFEV].

cxix. Shen, supra note cxi; Abbott Laboratories Market Cap 2006-2019, MACROTRENDS, https:/www.macrotrends.net/stocks/charts/ABT/abbott-laboratories/market-cap

[https://perma.cc/8TK3-5CYW].

cxx. Jof Enriquez, Abbott Completes $\$ 25$ Billion Purchase of St. Jude Medical, MED DEVICE ONLINE (Jan. 6, 2017), https:/www.meddeviceonline.com/doc/abbott-completes-billionpurchase-of-st-jude-medical-0001 [https://perma.cc/95L9-EHMS].

cxxi. Shen, supra note cxi; Microsoft Market Cap 2006-2019, MACROTRENDS, https:/www.macrotrends.net/stocks/charts/MSFT/microsoft/market-cap [https://perma.cc/J7K4N49M].

cxxii. Ashley Stewart, Microsoft Clears Final Regulatory Hurdle, \$26B LinkedIn Acquisition to Close in 'Coming Days', Puget Sound Bus. J. (Dec. 6, 2016, 2:47 PM), https://www.bizjournals.com/seattle/news/2016/12/06/microsoft-clears-final-regulatory-hurdle26b.html [https://perma.cc/4U37-MRWB].

cxxiii. CenturyLink To Buy Level 3 Communications for About \$24 Billion, CNBC (Oct. 31, 2016, 10:25 AM), https://www.cnbc.com/2016/10/31/centurylink-agrees-to-buy-level3-communications-in-34-billion-deal.html [https://perma.cc/NS65-JNZQ]; CenturyLink Market Cap 2006-2019, MACROTRENDS, https:/www.macrotrends.net/stocks/charts/CTL/centurylink/market-cap

[https://perma.cc/VF5H-GXFX].

cxxiv. Mari Silbey, DOJ Blesses CenturyLink, Level 3 Merger . . with Conditions, LiGHTREADING (Oct. 3, 2017), https://www.lightreading.com/services/broadband-services/doj- 


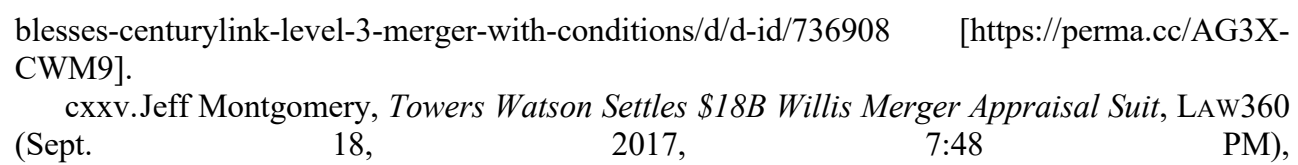
https://www.law360.com/mergersacquisitions/articles/965172/towers-watson-settles-18b-willismerger-appraisal-suit [https://perma.cc/EX8Q-7W9Y]; Willis Towers Watson Public Market Cap 2006-2019, MACROTRENDS, https://www.macrotrends.net/stocks/charts/WLTW/willis-towerswatson-public/market-cap [https://perma.cc/H897-KT68].

cxxvi. Willis Towers Watson Merger Successfully Completed, Business WIRE (Jan. 5, 2016, 1:00 AM), https:/www.businesswire.com/news/home/20160104006634/en/WillisTowers-Watson-Merger-Successfully-Completed [https://perma.cc/9QV9-2YH2].

cxxvii. Shen, supra note cxi; Johnson Controls Reports 2016 Fiscal Fourth Quarter and Full Year Earnings, Johnson CONTROLS (Nov. 8, 2016), http://investors.johnsoncontrols.com/news-and-events/press-releases/johnson-controlsinternational-plc/2016/11-08-2016-115528492 [https://perma.cc/497B-CG42].

cxxviii. Thomas Content, Johnson Controls Eyes Faster Completion of Tyco Merger, on Sept. 2, J. SenTiNEL (July 21. 2016), http://archive.jsonline.com/business/johnson-controlseyes-faster-completion-of-tyco-merger-on-sept-2-b99765353z1-387782611.html [https://perma.cc/2328-RDSG].

cxxix. Shen, supra note cxi; Marriott Market Cap 2006-2019, MACROTRENDS, https:/www.macrotrends.net/stocks/charts/MAR/marriott/market-cap [https://perma.cc/MV59KGNU].

cxxx.Marriott and Starwood Announce Achievement of Key Milestones in Antitrust Review of Marriott's Proposed Acquisition of Starwood, MARRIOTT (Mar. 1, 2016), https://marriott.gcsweb.com/news-releases/news-release-details/marriott-and-starwood-announce-achievementkey-milestones [https://perma.cc/3CYE-AAEM].

cxxxi. Shen, supra note cxi; Annual Report 2016, TransCanada (Feb. 2017), https://www.transcanada.com/globalassets/pdfs/investors/reports-and-filings/annual-andquarterly-reports/2016/transcanada-2016-annual-report.pdf [https://perma.cc/339W-DCLA].

cxxxii. Columbia Pipeline Partners, Columbia Pipeline Group Approve Merger, N. AM. OIL \& GAS PIPELINES (Feb. 17, 2017), https://napipelines.com/cppl-cpg-announce-mergerapproval/ [https://perma.cc/Z5JU-Y6M9].

cxxxiii. Shen, supra note cxi; Fortis Market Cap 2016-2019, MACROTRENDS, https://www.macrotrends.net/stocks/charts/FTS/fortis/market-cap [https://perma.cc/DDQ2CQDH].

cxxxiv. $\quad$ Fortis Completes Acquisition of ITC for US\$11.3 Billion, DAVIES (Oct. 14, 2016), https://www.dwpv.com/en/Insights/News/Announcements/2016/Fortis-CompletesAcquisition-of-ITC-for-US-11-Billion [https://perma.cc/B4QG-BEEE].

cxxxv. Shen, supra note cxi; Sherwin-Williams Market Cap 2006-2019, MACROTRENDS, https://www.macrotrends.net/stocks/charts/SHW/sherwin-williams/market-cap [https://perma.cc/9RXS-N2L6].

cxxxvi. $\quad$ FTC Requires Sherwin-Williams To Divest Assets as a Condition of Acquiring Valspar, FTC (May 26, 2017), https://www.ftc.gov/news-events/press-releases/2017/05/ftcrequires-sherwin-williams-divest-assets-condition-acquiring [https://perma.cc/6KSN-7DJB].

cxxxvii. Geoffrey Smith \& Claire Groden, Pfizer, Allergan Confirm $\$ 160$ Billion Merger Deal, ForTune (Nov. 23, 2015, 6:00 AM), http://fortune.com/2015/11/23/pfizerallergan-merger/; Pfizer Market Cap 2006-2019, MACROTRENDS, 
https://www.macrotrends.net/stocks/charts/PFE/pfizer/market-cap

[https://perma.cc/9L9FD5Y3].

cxxxviii. Caroline Humer \& Ankur Banerjee, Pfizer, Allergan Scrap \$160 Billion Deal After U.S. Tax Rule Change, REUTERS (Apr. 6, 2016, 3:54 AM), https://www.reuters.com/article/us-allergan-m-a-pfizer-idUSKCN0X3188

[https://perma.cc/E2AG-GR2P].

cxxxix. Dan Primack, Dow Chemical and DuPont Announce Mega-Merger, FortunE (Dec. 11, 2015, 5:00 AM), http://fortune.com/2015/12/11/dow-chemical-and-dupont-announcemega-merger/; DuPont De Nemours Market Cap 2006-2019, MACROTRENDS, https://www.macrotrends.net/stocks/charts/DWDP/dow-chemical/market-cap [https://perma.cc/TKP3-JNRE].

cxl. Diane Bartz, Dow, DuPont Merger Wins U.S. Antitrust Approval with Conditions, REUTERS (June 15, 2017, 1:15 PM), https://www.reuters.com/article/us-du-pont-m-a-dow/dowdupont-merger-wins-u-s-antitrust-approval-with-conditions-idUSKBN1962SN

[https://perma.cc/X3QF-PRDU].

cxli. Dan Burrows, 10 Biggest Mergers and Acquisitions of 2015, INVESTORPLACE (Dec. 29, 2015, 2:21 PM), https://investorplace.com/2015/12/2015-mergers-and-acquisitions/ [https://perma.cc/FZ9K-Y2TU]; Charter Communications Market Cap 2006-2018, MACROTRENDS, https:/www.macrotrends.net/stocks/charts/CHTR/chartercommunications/market-cap [https://perma.cc/LVB5-P5YP].

cxlii. Press Release, Dept. of Justice, Justice Department Allows Charter's Acquisition of Time Warner Cable and Bright House Networks to Proceed with Conditions, Dept. of Justice Press Release 16-492 (Apr. 25, 2016), https://www.justice.gov/opa/pr/justice-department-allowscharter-s-acquisition-time-warner-cable-and-bright-house-networks [https://perma.cc/3SYA$72 Z X]$.

cxliii. Javier Blas \& Rakteem Katakey, Shell Will Buy BG Group for $\$ 70$ Billion in Cash, Shares, BloOMBERG (Apr. 7, 2015, 11:50 AM), https://www.bloomberg.com/news/articles/2015-04-08/shell-will-buy-bg-group-for-70-billionin-cash-and-shares [https://perma.cc/3ZMY-M8F2]; Royal Dutch Shell Market Cap 2006-2019, MACROTRENDS, https://www.macrotrends.net/stocks/charts/RDS.B/royal-dutch-shell/market-cap [https://perma.cc/PC7M-VDSJ].

cxliv.Jordan Blum, Shell-BG Deal Gets U.S. Antitrust OK, Houston Chron. (June 16, 2015), https:/www.houstonchronicle.com/business/energy/article/Shell-BG-deal-gets-U-S-antitrustOK-6331503.php [https://perma.cc/WLQ3-MU3A].

cxlv. Burrows, supra note cxli; Dell Technologies Market Cap 2006-2019, MACROTRENDS, https:/www.macrotrends.net/stocks/charts/DVMT//market-cap [https://perma.cc/U4YVQYMS].

cxlvi. Press Release, Dell Technologies, Inc., Dell and EMC Receive US Federal Trade Commission Clearance for Proposed Merger (Feb. 23, 2016, 9:24 PM), https://investors.delltechnologies.com/news-releases/news-release-details/dell-and-emc-receiveus-federal-trade-commission-clearance [https://perma.cc/3572-EWAE].

cxlvii. Burrows, supra note cxli; Kraft Heinz Market Cap 2011-2019, MACROTRENDS, $\quad$ https://www.macrotrends.net/stocks/charts/KHC/kraft-heinz/market-cap [https://perma.cc/KSJ8-T4U4].

cxlviii. Press Release, Kraft Heinz Co., H.J. Heinz Company and Kraft Foods Group Announce Expiration of Hart-Scott-Rodino Waiting Period (June 9, 2015, 8:45 AM), http://ir.kraftheinzcompany.com/news-releases/news-release-details/hj-heinz-company-andkraft-foods-group-announce-expiration-0 [https://perma.cc/6CAN-AEHL]. 
cxlix.Burrows, supra note cxli; Anthem Market Cap 2006-2019, MACROTRENDS, https:/www.macrotrends.net/stocks/charts/ANTM/anthem/market-cap [https://perma.cc/K92EVKKA].

cl. David Dranove, The Anthem-Cigna Merger: A Post-Mortem, HeAlthAfFAIRs (Sept. 5, 2017), https://www.healthaffairs.org/do/10.1377/hblog20170905.061802/full/ [https://perma.cc/EE5C-67ZZ].

cli. Burrows, supra note cxli; Energy Transfer Partners Market Cap 2006-2019, MACROTRENDS, [https://perma.cc/9RCG-7DGE].

clii. Energy Transfer-Williams Companies Merger Approved with Conditions, REUTERS (June 9, 2016, 11:45 PM), https:/www.reuters.com/article/us-williams-m-a-energy-usftc/energy-transfer-williams-companies-merger-approved-with-conditions-idUSKCN0YV296 [https://perma.cc/Q425-47VZ].

cliii. Chad Bray, British American Tobacco to Take Over Reynolds American in $\$ 49$ Billion Deal, N. Y. Times (Jan. https:/www.nytimes.com/2017/01/17/business/dealbook/british-american-tobacco-reynoldscigarettes-merger.html [https://perma.cc/3GEP-L8DK]; British American Tobacco Market Cap 2006-2019, MACROTRENDS, https:/www.macrotrends.net/stocks/charts/BTI/british-americantobacco/market-cap [https://perma.cc/9QXP-Q9Y8].

cliv. Proposed BAT Acquisition of RAI Clears U.S. Antitrust Hurdle, Cision (Mar. 9, 2017), https://www.prnewswire.com/news-releases/proposed-bat-acquisition-of-rai-clears-us-antitrusthurdle-300421086.html [https://perma.cc/YVX2-AAFH].

clv. Katherine Chiglinsky \& Sonali Basak, Buffett to Acquire Precision Castparts in \$37.2 Billion Deal, BloOMBerg (Aug. 10, 2015, 5:17 AM), https://www.bloomberg.com/news/articles/2015-08-10/buffett-agrees-to-buy-precisioncastparts-in-37-2-billion-deal [https://perma.cc/3HKF-G5FK]; Berkshire Hathaway Market Cap 2006-2019, MACROTRENDS, https://www.macrotrends.net/stocks/charts/BRK.A/berkshirehathaway/market-cap [https://perma.cc/E2W6-4GSE].

clvi. Berkshire Hathaway Completes Acquisition of Precision Castparts, GLOBENEwswIRE (Jan. 29, 2016, 4:01 PM), https://www.globenewswire.com/newsrelease/2016/01/29/806102/0/en/Berkshire-Hathaway-Completes-Acquisition-of-PrecisionCastparts.html [https://perma.cc/WGH5-TGC9].

clvii. Aetna to Acquire Humana for $\$ 37$ Billion, Combined Entity to Drive ConsumerFocused, High-Value Health Care, CVS HeAlth (July 3, 2015), https:/cvshealth.com/newsroom/press-releases/aetna-acquire-humana-37-billion-combinedentity-drive-consumer-focused-high [https://perma.cc/2PTU-K2WN]; Aetna Market Cap 20062019, MACROTRENDS, https://www.macrotrends.net/stocks/charts/AET//market-cap [https://perma.cc/UQ33-YPYZ].

clviii. Rebecca Hersher, Aetna and Humana Call Off Merger After Court Decision, NPR (Feb. 14, 2017, 11:41 AM), https://www.npr.org/sections/thetwoway/2017/02/14/515167491/aetna-and-humana-call-off-merger-after-court-decision [https://perma.cc/8VAW-4KZ9].

clix. Laurie Kulikowski, The 10 Biggest U.S. M\&A; Deals in 2015, TheStreEt (Jun. 12, 2015 , $11: 56$

AM), https://web.archive.org/web/20190505042655/https://www.thestreet.com/story/13184146/1/the10-biggest-us-ma-deals-in-2015.html [https://perma.cc/62PS-R8JR]; Mylan Market Cap 20062019, MACROTRENDS, https://www.macrotrends.net/stocks/charts/MYL/mylan/market-cap [https://perma.cc/SGJ6-7BHQ]. 
clx. Greg Hammond, Perrigo Resists Acquisition Despite Mylan, FTC Settlement, ABOVE THE LAW, https://abovethelaw.com/2015/11/perrigo-resists-acquisition-despite-mylan-ftcsettlement/ [https://perma.cc/KY9K-UVU8].

clxi. Avago Technologies to Acquire Broadcom for $\$ 37$ Billion, BROADCOM (May 28, 2015), http://investors.broadcom.com/phoenix.zhtml?c=203541\&p=irol-newsArticle \&ID=2053937

[https://perma.cc/62RG-V4K5]; see \#207 Avago Technologies, America's Best Midsize Employers 2016, FORBES (May 6, 2015), https://www.forbes.com/companies/avagotechnologies/\#6483901f28dd [https://perma.cc/L4T4-MWSL].

clxii. Avago Secures Unconditional EU Approval for \$37 Billion Broadcom Buy, REUTERS (Nov. 23, 2017, 5:26 AM), https://www.reuters.com/article/us-broadcom-m-a-avago-euidUSKBN0TC14T20151123 [https://perma.cc/5Z24-A7TQ].

clxiii. Shire, Baxalta Tie the Knot in $\$ 32 B$ Merger, GEN (Jan. 11, 2016), https:/www.genengnews.com/news/shire-baxalta-tie-the-knot-in-32b-merger/81252213/

[https://perma.cc/XSE4-NZCM]; Shire Market Cap 2005-2019, MACROTRENDS, https://www.macrotrends.net/stocks/charts/SHPG//market-cap [https://perma.cc/5HXP-RUJV].

clxiv. Don Seiffert, Shire Completes Baxalta Acquisition, Creating State's Biggest Pharma Company, Bos. Bus. J. (June 3, 2016, 8:10 AM), https://www.bizjournals.com/boston/blog/bioflash/2016/06/shire-completes-baxalta-acquisitioncreating.html [https://perma.cc/PCF5-BDTA].

clxv. AbbVie to Acquire Pharmacyclics, Including its Blockbuster Product Imbruvica, Creating an Industry Leading Hematological Oncology Franchise, CISION (Mar. 04, 2015), https://www.prnewswire.com/news-releases/abbvie-to-acquire-pharmacyclics-including-itsblockbuster-product-imbruvica-creating-an-industry-leading-hematological-oncology-franchise300045951.html [https://perma.cc/8LJT-SX66]; AbbVie Market Cap 2010-2019, MACROTRENDS, https://www.macrotrends.net/stocks/charts/ABBV/abbvie/market-cap [https://perma.cc/6FEXEK9Q].

clxvi. AbbVie Announces Expiration of Hart-Scott-Rodino Waiting Period for AbbVie's Acquisition of Pharmacyclics, Cision (May 22, 2015), https://www.prnewswire.com/news-releases/abbvie-announces-expiration-of-hart-scott-rodinowaiting-period-for-abbvies-acquisition-of-pharmacyclics-300087801.html [https://perma.cc/6JG9-DY4K].

clxvii. Pfizer To Acquire Hospira, Pfizer (Feb. 5, 2015, 7:01 AM), https://www.pfizer.com/news/press-release/press-release-detail/pfizer_to_acquire_hospira [https://perma.cc/M8KG-KARB]; Pfizer Market Cap 200б-2019, MACROTRENDS, https://www.macrotrends.net/stocks/charts/PFE/pfizer/market-cap [https://perma.cc/4GXBQKSM].

clxviii. Pfizer Inc./Hospira, Inc., FTC (Oct. 19, 2015), https://www.ftc.gov/enforcement/cases-proceedings/151-0074/pfizer-inchospira-inc [https://perma.cc/F699-RUZL].

clxix.Barb Darrow, Official at Last: Intel Completes \$16.7 Billion Buy of Altera, ForTUNE (Dec. 28, 2015, 11:33 AM), https://fortune.com/2015/12/28/intel-completes-altera-acquisition; Intel Capket 2006-2019, MACROTRENDS, https://www.macrotrends.net/stocks/charts/INTC/intel/market-cap [https://perma.cc/4ZSQTR8Y].

clxx. Gibson Dunn, Getting Your Deal Through-Strategies for Increasing Deal CERTAINTY (Apr. 4, 2017), https://www.gibsondunn.com/wpcontent/uploads/documents/publications/WebcastSlides-Antitrust-Merger-Clearance-04-April2017.pdf [https://perma.cc/6LBB-PSSV]. 
clxxi. Merger \& Acquisition ETFs: Will 2016 Replicate 2015?, NASDAQ (Dec 15, 2015 12:50 PM), https://www.nasdaq.com/articles/merger-acquisition-etfs-will-2016-replicate2015-2015-12-15 [https://perma.cc/4EPA-QRDB]; NXP Semiconductors Market Cap 20092018, MACROTRENDS, https://www.macrotrends.net/stocks/charts/NXPI/nxpsemiconductors/market-cap [https://perma.cc/8MFD-VWXF].

clxxii. Diane Bartz, NXP Wins U.S. Antitrust Approval To Buy Freescale Semiconductor, REUTERS (Nov. 25, 2015, 1:52 PM), https://www.reuters.com/article/frsclsmcdtr-ma-nxp-semicondtrs-idUSL1N13K23H20151125 [https://perma.cc/5HXK-EBWA].

clxxiii. Valeant To Acquire Salix Pharmaceuticals for $\$ 158.00$ Per Share in Cash, Bausch HeAlth (Feb. 22, 2015), https://ir.bauschhealth.com/news-releases/2015/22-02-2015 [https://perma.cc/S5HP-D59H]; Bausch Health Cos Market Cap 2006-2019, MACROTRENDS, https://www.macrotrends.net/stocks/charts/BHC/bausch-health-cos/market-cap [https://perma.cc/YLG3-Y8R2]; see also James Passeri, What's Valeant Worth Without Salix?, $\begin{array}{lllll}\text { REAL MONEY (Nov. 2, 2016, } & \text { 28 } & \text { PM), }\end{array}$ https://realmoney.thestreet.com/articles/11/02/2016/whats-valeant-worth-without-salix

[https://perma.cc/557K-US5P].

clxxiv. Diane Bartz, Valeant Agrees To Sell Paragon To Settle U.S. Antitrust Charges, REUTERS (Nov. 7, 2016, 2:30 PM), https://www.reuters.com/article/us-valeant-ftc-paragonidUSKBN1322KN [https://perma.cc/M67N-KZ9K].

clxxv. Williams Announces Agreement to Acquire All Public Equity of Williams Partners L.P.; Plans 3Q 2015 Dividend Increase to \$0.64 or \$2.56 on an Annualized Basis; Expects Dividend Growth of 10\%-15\% Annually Through 2020, BuSINESS WIRE (May 13, 2015, 7:00 AM), https:/www.businesswire.com/news/home/20150513005294/en/WilliamsAnnounces-Agreement-Acquire-Public-Equity-Williams [https://perma.cc/5YYH-N8ZF]; The Williams Companies, Inc., YAHOO! FINANCE, https://finance.yahoo.com/quote/wmb?ltr=1 [https://perma.cc/GSL8-V5TV].

clxxvi. Pranav Ghumatkar, Williams Completes Acquisition of Williams Partners, SeEKING AlPhA (Aug. 10, 2018, 1:38 PM), https://seekingalpha.com/news/3381749-williamscompletes-acquisition-of-williams-partners [https://perma.cc/3Y2V-G5W8].

clxxvii. $\quad$ Sweta Singh \& Ankur Banerjee, Danaher to Buy Pall Corp in \$13.8 Billion Deal, Split into Two, REUTERS (May 13, 2015, 5:25AM), https://www.reuters.com/article/us-pallm-a-danaher/danaher-to-buy-pall-corp-for-13-8-bln-to-spilt-into-two-

idUSKBN0NY1GQ20150513 [https://perma.cc/VYA7-RANQ]; Danaher Market Cap 20062018, MACROTRENDS, https://www.macrotrends.net/stocks/charts/DHR/danaher/market-cap [https://perma.cc/RYD5-JPKF].

clxxviii. Ken Schachter, Pall Corp. Employees Face Corporate Culture Shock Under New Owner, NewSDAY (July 4, 2015, 6:15 PM), https://www.newsday.com/business/pall-corpemployees-face-corporate-culture-shock-under-new-owner-1.10607461

[https://perma.cc/MCZ7-C4DA].

clxxix. Catamaran and OptumRx To Combine, UnitedHealth Group (Mar. 30, 2015), https://www.unitedhealthgroup.com/newsroom/2015/0330optumrxcatamaran.html [https://perma.cc/Q5H7-KFHU]; OptumRx Acquires Catamaran, MERGR, https://mergr.com/optumrx-acquires-catamaran [https://perma.cc/7JLB-S9MK]; UnitedHealth Group Market Cap 2006-2019, MACROTRENDS, https://www.macrotrends.net/stocks/charts/UNH/unitedhealth-group/market-cap [https://perma.cc/R53F-A6AE]. 
clxxx. OptumRx, Catamaran Complete Combination, Optum (July 23, 2015), https://www.optum.com/about/news/optumrx-catamaran-complete-combination.html [https://perma.cc/DD35-MWMZ].

clxxxi. CVS Health and Omnicare Sign Definitive Agreement for CVS Health To Acquire Omnicare, CVS HEALTH (May 21, 2015), https://cvshealth.com/newsroom/pressreleases/cvs-health-and-omnicare-sign-definitive-agreement-cvs-health-acquire-omnicare [https://perma.cc/3WYR-74KE]; CVS Health Market Cap 2006-2019, MACROTRENDS, https://www.macrotrends.net/stocks/charts/CVS/cvs-health/market-cap [https://perma.cc/6ESH$3 \mathrm{X} 5 \mathrm{H}]$.

clxxxii. David Balto, FTC Must Carefully Investigate the CVS Health Omnicare Acquisition, THE HiLL (July 30, 2015, 10:00 AM), https://thehill.com/blogs/congressblog/healthcare/249664-ftc-must-carefully-investigate-the-cvs-health-omnicare [https://perma.cc/Q6HV-BTE9].

clxxxiii. Energy Transfer Partners to Buy Regency Unit for $\$ 11$ Billion, REUTERS (Jan. 26, 2015, 8:35 AM), https://www.reuters.com/article/us-regencyenergy-offerenergytransfer/energy-transfer-partners-to-buy-regency-unit-for-11-billionidUSKBN0KZ1QQ20150126 [https://perma.cc/Q63C-MDUN].

clxxxiv. Energy Transfer Partners and Regency Energy Partners Announce Successful Completion of Merger, Business WiRE (Apr. 30, 2015, 8:48 AM), https://www.businesswire.com/news/home/20150430005846/en/Energy-Transfer-PartnersRegency-Energy-Partners-Announce [https://perma.cc/BX8N-A297]. 